\title{
Leadership Orientations and Conflict Management Styles of Academic Deans in Masters Degree Institutions
}

\author{
Linda Kimencu \\ West Virginia University
}

Follow this and additional works at: https://researchrepository.wvu.edu/etd

\section{Recommended Citation}

Kimencu, Linda, "Leadership Orientations and Conflict Management Styles of Academic Deans in Masters Degree Institutions" (2011). Graduate Theses, Dissertations, and Problem Reports. 3028.

https://researchrepository.wvu.edu/etd/3028

This Dissertation is protected by copyright and/or related rights. It has been brought to you by the The Research Repository @ WVU with permission from the rights-holder(s). You are free to use this Dissertation in any way that is permitted by the copyright and related rights legislation that applies to your use. For other uses you must obtain permission from the rights-holder(s) directly, unless additional rights are indicated by a Creative Commons license in the record and/ or on the work itself. This Dissertation has been accepted for inclusion in WVU Graduate Theses, Dissertations, and Problem Reports collection by an authorized administrator of The Research Repository @ WVU.

For more information, please contact researchrepository@mail.wvu.edu. 
Leadership Orientations and Conflict Management

Styles of Academic Deans in Masters Degree Institutions

\author{
Linda Kimencu
}

A dissertation submitted to the College of Human Resources and Education at West Virginia University in partial fulfillment of the requirement for the degree of

Doctor of Education

in

Educational Leadership Studies

Paul Chapman,Ph.D.,Chair

Ernest Goeres, Ph.D

Reagan Curtis, Ph.D

Dan Hursh, Ph.D

Gerald Blakely,Ph.D

Department of Educational Leadership Studies

Morgantown, West Virginia

2011

Keywords: Leadership, Conflict management, Academic deans

(c) (7) (8) 2011 Linda Kimencu 


\title{
Abstract \\ Leadership Orientations and Conflict Management Styles of Academic Deans in Masters Degree Institutions
}

\author{
Linda Kimencu
}

Previous research suggests that academic deans follow the human relations and structural perspectives in conflict management (Feltner \& Goodsell, 1972). However, the position of an academic dean has been described to have undertones that are more political and social than hierarchical and technical. Hence, the current study evaluated the role of the academic dean in conflict management from a more inclusive perspective that involved the Bolman and Deal fourframe leadership theory: Structural, human resources, political and symbolic frames and Rahim Organizational Conflict Inventory (ROCI-II) instrument that evaluated the five dimensions of conflict management: Integrating, obliging, compromising, dominating, and avoiding. The respondents of the study included 93 academic deans heading Business and Education colleges in Public Masters Colleges and Universities-Larger programs (Carnegie Classification, 2010). The research found significant relationships between deans' leadership frames, styles, and conflict management styles: Integrating conflict management style was positively related to all the four frames; contrary to the dominating conflict management style which was negatively related to the human resource frame. An education dean was 2.59 times more likely to have a political frame than a business dean; deans with less than five years of experience in the position of an academic dean were 3.23 times more likely to have a human resource frame than deans with more experience in the position; and finally, deans with more than ten years of experience in academia were more likely to use the compromising conflict management style than deans with less experience in academia with a medium effect size of .24. This knowledge can be used during deanship trainings and job placements. 


\section{Dedication}

I dedicate this dissertation to my husband Shadrack and our son Alan; and to my parents, George and Lucy. Thank you for your unconditional love and support through this major milestone in my life. 


\section{Acknowledgements}

I would like to thank the Almighty God for giving me the grace, intellect, and favor in the completion of this degree. May this degree bring glory and honor to his name through service to his people. My appreciation also goes to all the wonderful and beautiful people that God has given to me to share my life with: My husband Shadrack and our son Alan, you have been such a great inspiration to me and your unconditional love, through this process, kept me going and aspiring for more.

To my chair, Dr. Paul Chapman, your mentorship and guidance through this process made me learn so much in a fun and inspiring way, I am so honored and grateful to have had a chance to work with you. Dr. Ernest Goeres, thank you very much for your wise counsel and your words of wisdom that I will remember for a very long time. Dr. Reagan Curtis, thank you very much for assisting me to not only do my data analysis but also for teaching me all the statistics methods classes and making me love to learn and someday maybe teach statistics to other students. Dr. Dan Hursh, thank you very much for your thoughtful insights through this dissertation; Dr. Gerald Blakely thank you for your words of encouragement through the process and finally, Dr. Richard Hartnett thanks for the support, intellect, and brilliance in assisting me to conceptualize the dissertation topic. I sincerely appreciate it all.

They say, "It takes a village to raise a child", well, I say it took so many more people to have this dissertation and the doctoral program started and completed. My gratitude goes to Jennifer McIntosh, Executive Officer for Social Justice, through the minority doctoral program for allotting a graduate assistantship position for me- that help has gone a long way. Thank you very much. This acknowledgement will not be complete if I do not acknowledge the staff at the 
Hildebrandt Early Learning Center for taking very good care of my son, while I spent hours in the library to complete the dissertation. I truly appreciate that support.

Last, but definitely not least, I acknowledge my parents: George and Lucy for instilling a love for learning in me and for giving my siblings and me the chance to pursue education. Dad, I will always remember your greatest reason for always wanting us to study and reach the highest heights: So that we can know our rights. I am proud to inform you that, that goal has been met and I am so grateful to God for your wisdom. Thank you mum, for being the rock of our family; your strength, determination, and love follows us wherever we go. I pray that God may give you two, a long, fulfilled life, full of his blessings and grace. To my two sisters: Emma and Lena, I pray that this will be an inspiration to you, that really the sky is the only limit. You can become whatever you want to become, if only you believe.

To my friends and family, faculty, colleagues, classmates, and everyone who crossed my path to make this beautiful day happen. I appreciate it all and my God bless you all. 


\section{Contents}

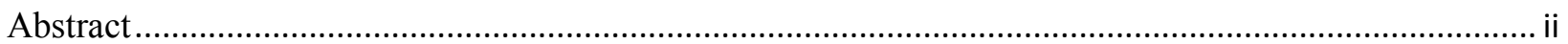

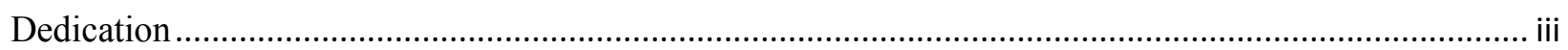

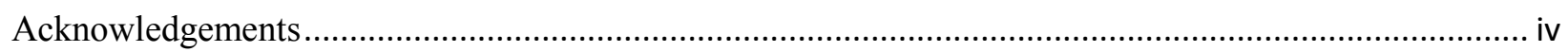

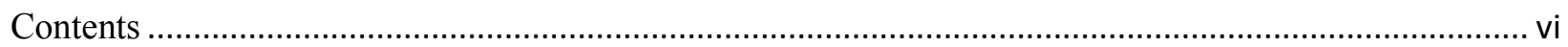

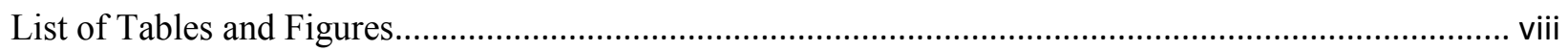

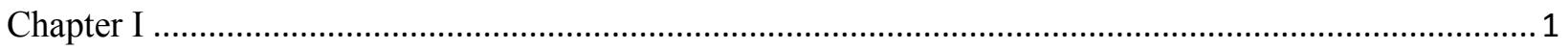

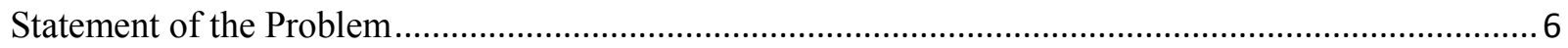

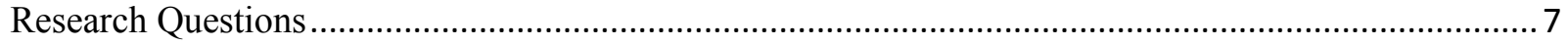

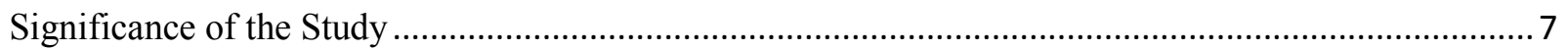

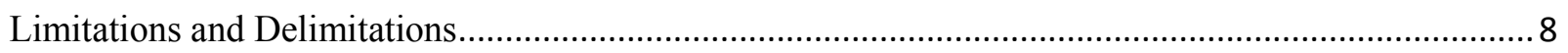

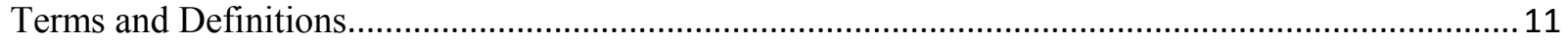

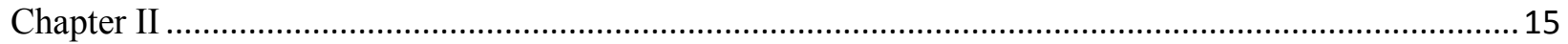

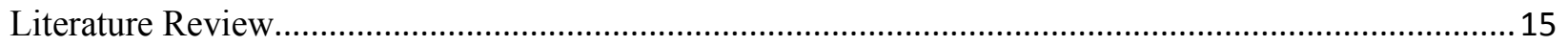

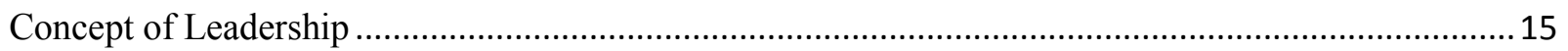

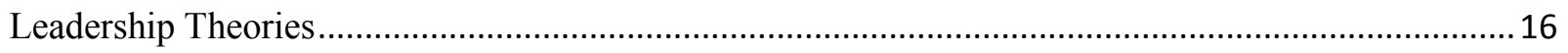

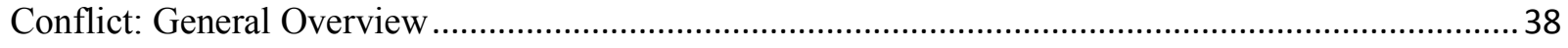

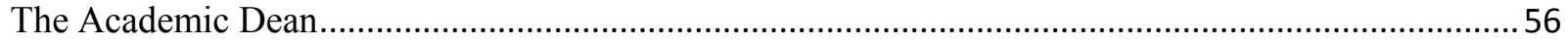

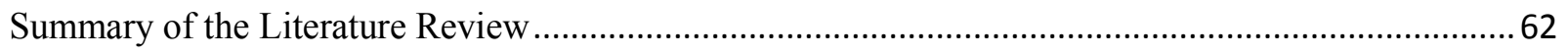

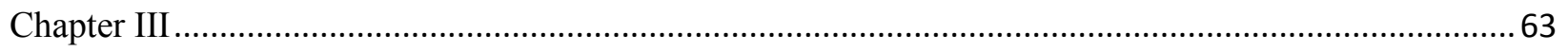

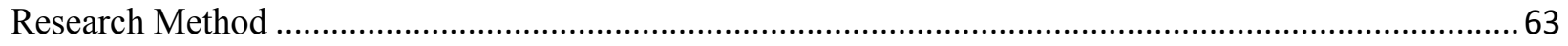

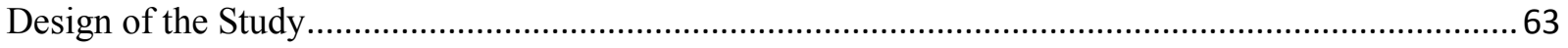

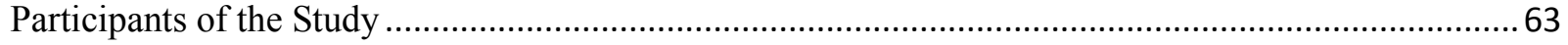

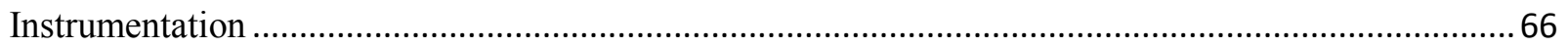

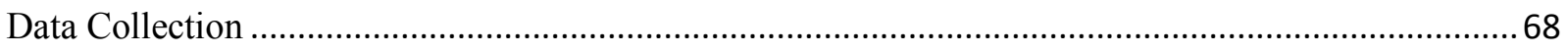

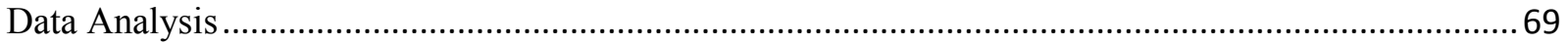

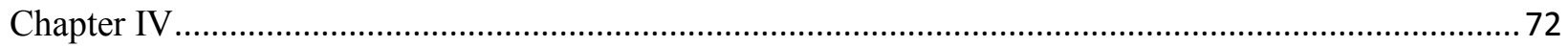

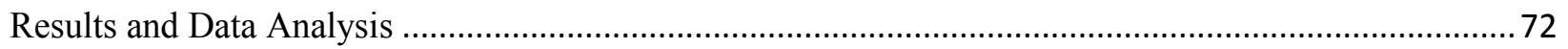

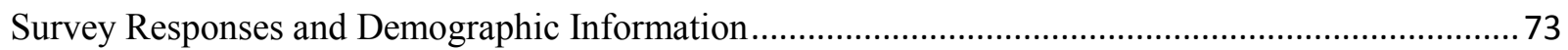




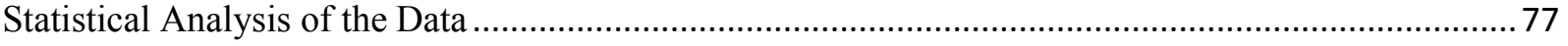

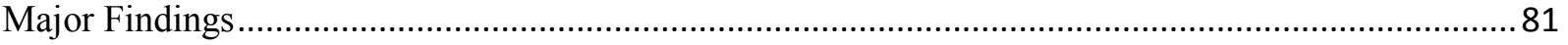

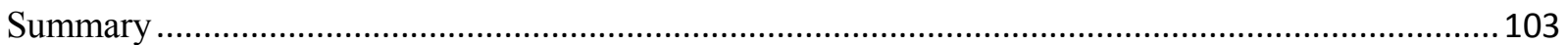

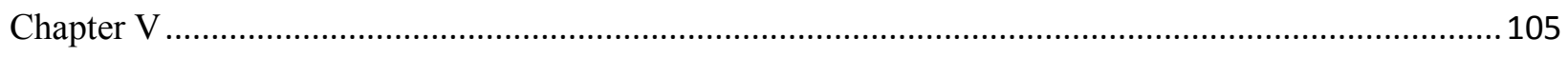

Summary, Discussions, Conclusions, and Recommendations ........................................................ 105

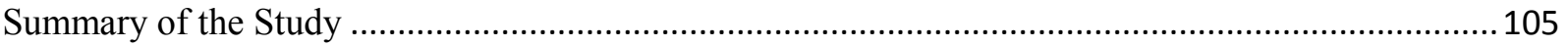

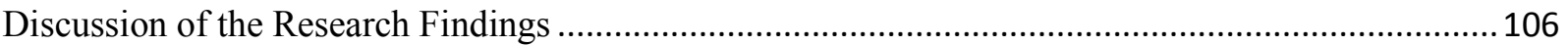

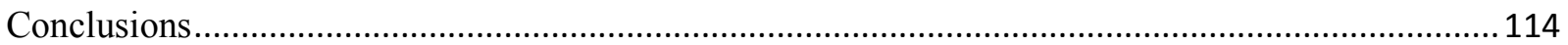

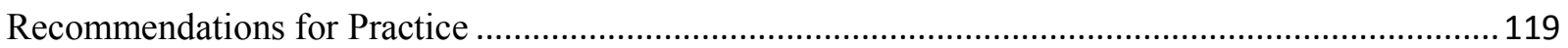

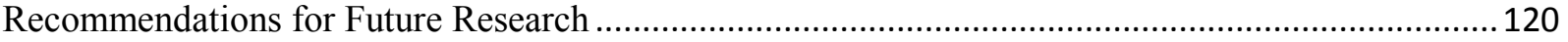

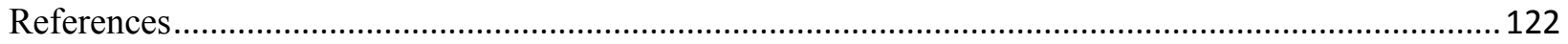

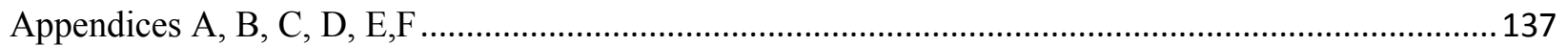

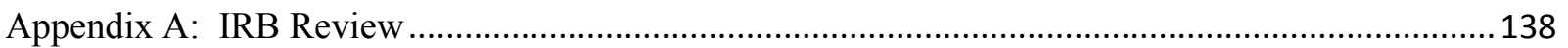

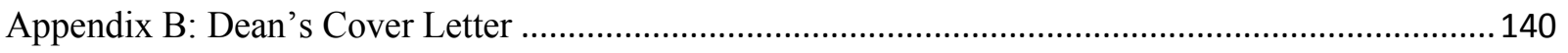

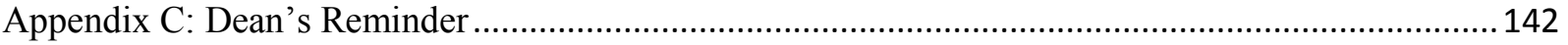

Appendix D: Permission to use Leadership Orientation Instrument (LOI-Self) ................................. 145

Appendix E: Permission to use Rahim Organizational Conflict Inventory- II .................................... 149

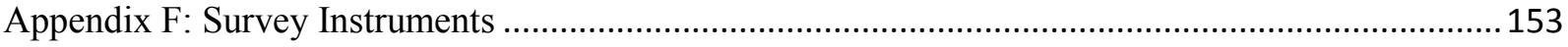

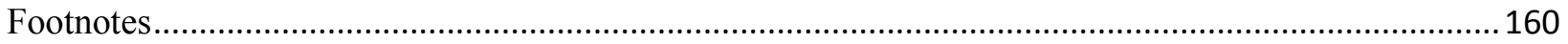




\section{List of Tables and Figures}

\begin{tabular}{|c|c|c|}
\hline Table & & Page \\
\hline 1 & Names of colleges and number of academic deans & 65 \\
\hline 2 & Academic deans' demographic information & 74 \\
\hline 3 & Academic deans' terminal degrees & 76 \\
\hline 4 & $\begin{array}{l}\text { Testing the assumptions of normality and equality } \\
\text { of variance }\end{array}$ & 78 \\
\hline 5 & $\begin{array}{l}\text { Leadership frames of Business and Education } \\
\text { deans in Masters institutions }\end{array}$ & 83 \\
\hline 6 & $\begin{array}{l}\text { Leadership styles of Business and Education } \\
\text { deans in Masters institutions }\end{array}$ & 83 \\
\hline 7 & Frequency distribution of styles by frames & 84 \\
\hline 8 & $\begin{array}{l}\text { Conflict management styles of Business and } \\
\text { Education deans in Masters institutions }\end{array}$ & 86 \\
\hline 9 & $\begin{array}{l}\text { Demographic frequencies of academic deans } \\
\text { leadership frames }\end{array}$ & 88 \\
\hline 10 & Type of college and political frame & 91 \\
\hline 11 & $\begin{array}{l}\text { Number of years as a dean and the human } \\
\text { resource frame }\end{array}$ & 91 \\
\hline 12 & $\begin{array}{l}\text { Demographic frequencies of academic deans } \\
\text { leadership styles }\end{array}$ & 92 \\
\hline 13 & $\begin{array}{l}\text { Differences between academic deans' conflict } \\
\text { management styles and demographic variables }\end{array}$ & 95 \\
\hline
\end{tabular}


14 Compromising conflict management style and number of years in academia

15 Correlation between leadership frames and leadership styles

16 Correlation between leadership frames and conflict management styles

\begin{tabular}{clc}
\hline Figures & & Page \\
\hline 1 & Blake and Mouton's Managerial grid & 22 \\
2 & Situational leadership model & 24 \\
3 & $\begin{array}{l}\text { Association between academic deans' } \\
\text { leadership frames and demographic information }\end{array}$ & 90 \\
4 & $\begin{array}{l}\text { Association between academic deans' } \\
\text { leadership styles and demographic information }\end{array}$ & 94 \\
\hline
\end{tabular}




\section{Chapter I}

\section{Leadership Orientations and Conflict Management Styles of Academic Deans in Masters \\ Degree Institutions}

Conflicts in institutions of higher learning are expanding in scope and magnitude and are becoming more challenging and complex because of changes facing academia. Higher education institutions are facing economic challenges that are compelling administrators to make difficult financial decisions such as freezing college salaries, discontinuing programs, laying-off workers, and reducing financial aid among other financial decisions which are significant sources of conflicts (Olson, 2007). In addition, universities are admitting diverse student population with more students being older, attending college part-time, working full-time, and fulfilling family responsibilities which are potential sources of conflict for the higher education student and the institution (Landa-Gonzales, 2008; Wolverton \& Gmelch, 2002). Moreover, institutions continue to face disputes regarding faculty-students relations, sexual harassment policies among other campus specific conflicts such as those involving academic freedom and research (Volpe \& Chandler, 1998). Nevertheless, academic deans by legitimacy of their position as academic leaders and administrators have a role to intervene in organizational conflicts- because conflicts can take more than 25\% of a supervisors time (Mintzberg, 1975)- and deans' leadership orientation could predispose their choice of a conflict management style. Administrators should therefore evaluate these two important functions of leadership, leadership orientations and conflict management styles, because leadership effectiveness is contingent on effective conflict management.

Conflicts refer to the exercise of power between two or more parties in an attempt to attain mutually incompatible goals (Fink, 1968) and can occur on four levels: Intra-personal, 
interpersonal, intra-group, and intergroup (Rahim, 1985). Because conflict is multi-faceted, a leader who addresses it from multiple perspectives is likely to be more effective than one who does not. Bolman and Deal (1991a, 1991b, 2003) identified four distinct lenses through which leaders frame their organizations: Structural, human resources, political, and symbolic. They argued that the ability to use multiple frames in addressing organizational issues can yield effective leadership.

The structural frame emphasizes on goals, specialized roles, and formal relationships; the human relations frame tailors the organization to meet the needs of their employees; the political frame perceives organizations as arenas in which people compete for power and scarce resources; whereas the symbolic frame abandons assumptions of rationality and views organizations from the perspectives of cultures, rituals, and ceremonies. Since multiple voices are competing for manager's attention; leaders who view the organization from various perspectives are likely to be more effective than those who do not. Bolman and Deal (2003) assert that "a good frame makes it easier to know what you are up against and what you can do about it" (p.13).

Similar to the Bolman and Deal four-frame leadership theory; academic deans function within four models of higher education governance: Bureaucratic, collegial, political, and anarchical (Baldridge, 1971, Cohen \& March, 1986; Geiger, 1989; McCarty \& Reyes, 1987). Bureaucratic deans develop policies and procedures that facilitate institutional decision-making; collegial deans aim at promoting consensus between faculty members and administration; deans who work within a political model perceive universities as coalitions of interest groups and hence assume the role of mediating between conflicting interests. Finally, deans who perceive the institutions as organized anarchy identify their role as managers of meaning with a 
responsibility to provide solutions to ill-defined problems (Baldridge, 1971; Cohen \& March, 1986; Geiger, 1989; McCarty \& Reyes, 1987).

Deans' pivotal role as middle managers exposes them to various conflicting expectations. As members of the president's cabinet and as leaders of faculty, deans experience intra-personal conflict because of conflicting role expectations (M. Wolverton, L.M. Wolverton, \& Gmelch, 1999). Deans could also experience interpersonal and inter-organizational conflicts when they assume the role of a dispute negotiator. They may be asked to negotiate disagreements regarding how resources are shared within the college, personnel problems, short-falls in budgets, personality clashes, and communication barriers among other disputes which could be significant sources of conflict (Donovan, 1993). Although handling conflicts in institutions is difficult, the effectiveness of leaders depend on it (Martin, 1993; M. Wolverton \& Gmelch, 2002) and the leadership orientations that they hold could determine how effectively they handle conflicts.

According to Feltner and Goodsell (1972), academic deans can perform the role of conflict initiators, defendants, and mediators. Deans act as initiators of conflict when they take up the responsibility to introduce change in the institutions. Efforts to instigate change in areas such as curriculum development, instructional innovation, or administrative polices could be met with resistance which could result in conflict between the dean and other members of the academy. Academic deans can also perform the role of the conflict defendant in the event their policies or directives are disputed. For instance, deans may be impelled to defend decisions regarding faculty tenure and promotions, budget cuts and allocations, and curriculum reforms when disputed. Finally, academic deans could be called upon to mediate between departmental conflicts, institutional conflicts, conflicts between colleges, student-faculty conflicts, facultyadministration conflicts, or conflicts among members of faculty. Feltner and Goodsell also 
recognized that academic deans "followed either of two diametrically opposite theories of conflict management: Authoritarian or human relations doctrines" (p.693). However, these two approaches to handling conflict are considered insufficient because they are oblivious of the political and symbolic perspectives of handling conflict. Hence, this research aimed at adding to the existing literature on conflict management by evaluating the conflict management styles from the four perspectives of leadership frames: Structural, human resource, political, and symbolic.

According to Fisher, Ury, and Patton (1991), conflicts occur when individuals differ in their interpretation of facts because of differences in their perceptions. Although the objective issue causing conflict exists; it is the subjective experience or perception of the disputants that determine the nature of conflict and how it can be resolved. Hence, disputants may view the same conflict in different ways because of differences in their opinions, experiences, or cognitive frameworks (Pinkley \& Northcraft; 1994). Correspondingly, deans encounter conflicting situations with differing perceptions which are shaped by their personal attitudes, interests, experiences, and desires (Feltner \& Goodsell, 1972). They confront the situation with a defined cognitive framework which helps them determine what is important and what can be safely ignored (Bensimon, 1987).

Conflict management strategies can take a variety of forms. Kaplowitz (1984) identified seven strategies that a disputant can employ when handling conflict ranging from a totalist approach with the goal of complete victory to latent acceptance of the opponents strategy. Other researchers have developed two-dimension grids to measure conflict management: Deutsch (1949) analyzed conflict management on the dimension of cooperation and competition; Blake and Mouton (1964) “concern for production" and "concern for people"; Thomas (1976) assertiveness and cooperativeness; finally Rahim (1983) defined them as "concern for self" 
versus "concern for others". To advance these conflict management approaches, five distinct instruments have been developed: Hall conflict management survey (1969), Thomas-Kilmann Management of difference exercise (MODE) survey (1974), Putnam-Wilson Organizational communication conflict instrument (OCCI) (1982), Ross-De Wine conflict management message style (1982) and Rahim Organizational Conflict Inventory-II (ROCI-II) (1983). Out of the five conflict management instruments; MODE and ROCI-II instruments are the most dominant for their empirical validity (Ben-Yoav \& Banai, 1992; Weider-Hatfield, 1988; Womack, 1988).

The ROCI-II instrument was selected for this study because it highlights on the effect of a person's predispositions in choosing a conflict management style. In addition to this, it not only interprets the conflict management style adopted by members, but also it offers recommendations for intervening in organizational conflicts. Moreover, the instrument has been credited for distinguishing the different conflict management strategies applied by individuals toward their superiors, subordinates, and peers (Weider-Hatfield, 1988). This distinction is vital to this research because the study assumed that deans would adjust their conflict management styles to suit their audience. Besides this, ROCI-II instrument was considered because it scores higher internal reliability than all other conflict management instruments (Ben-Yoav \& Banai, 1992).

ROCI-II instrument measures five conflict management styles: Integrating, obliging, compromising, dominating, and avoiding (Rahim, 1983). The integrating style of handling conflict has high concern for self and high concern for others. The people in dispute look for an optimum solution that leads to a win-win outcome; this style aims at joint problem-solving. The obliging style has high concern for others and low concern for self. The obliging contesters disregard their interests and aim at satisfying the opponent's interests; this style leads to a lose- 
win outcome. The compromising style of conflict management aims at finding a middle ground through negotiations and bargains. It ensures that none of the parties either win or lose in the conflict. Opposite to the obliging style is the dominating style of conflict management, the dominating person has high concern for self and low concern for others; this orientation is associated with forcing behavior to win one's position. Finally, the avoiding conflict management style has low concern for self and low concern for others. The avoiding contenders fail to satisfy their concerns and those of others by ignoring or eluding the issue of contention (Rahim, 1983; Weider-Hatfield, 1988). Although most recommendations for organizational conflict relate to conflict resolution, reduction, or minimization; functional levels of conflict need not be eliminated or reduced rather they need to be managed (Rahim, 1985). Academic administrators should therefore ensure that moderate levels of conflict are maintained to sustain optimum organizational effectiveness; this is because effectual leadership is contingent on effective conflict management (Garnier, 1981; Rahim, 1985).

\section{Statement of the Problem}

Previous research shows that academic deans follow either the structural or human relations approach when dealing with conflicts (Feltner \& Goodsell, 1972). Deans, who follow the structural mindset, handle conflict by the directives of their superiors. On contrary, deans who follow the human relations theory perceive conflict to be harmful and when it arises they may ignore it, settle it by compromise, or follow institutional policy. These two approaches to handling conflict are considered insufficient because they are oblivious of the political and symbolic cognition theories that are significant in evaluating conflict. Understanding deans' role in conflict management from a comprehensive perspective is essential because the deans' 
position has undertones that are political and social than technical and hierarchical (Rosser, Johnsrud, \& Heck, 2003).

Hence, the problem is that no research has been done to address the relationship between deans' four leadership frames- structural, human resources, political, and symbolic- and styles: No frame, single frame, paired frame, and multi-frame; with Rahim's five conflict management styles: Integrating, obliging, compromising, dominating and avoiding. The purpose of this research was therefore to identify the relationship between academic deans' leadership orientations and conflict management styles. The research findings have added to the existing knowledge on leadership and conflict management styles and may be used during leadership trainings and job placements among academic deans.

\section{Research Questions}

The following research questions were addressed by the study:

1. What leadership frames, styles, and conflict management styles do academic deans in Masters College and Universities demonstrate?

2. Are there significant differences between deans' leadership frames, styles, and conflict management styles in the context of gender, experience, faculty size, or type of college?

3. Are there significant relationships between deans' leadership frames, styles, and conflict management styles?

\section{Significance of the Study}

This study has contributed to the body of knowledge in the area of leadership studies, higher education governance, conflict management, and human relations studies. Its findings would enlighten the deans on the relationship of leadership orientations and conflict management and hence inform practice. Dean's ability to examine their inclinations in a conflict situation 
might enable them to assess the feasible conflict management style to espouse (Jones \& White, 1985). Conflict is inevitable in organizational decision-making and leaders have a role to intervene in it; the study is therefore considered significant because it evaluated important executive functions for higher education administrators: Leadership and conflict management.

The study also added to the existing knowledge on conflict management among academic deans by adding the political and symbolic cognitive approaches, as supplementary approaches, to the structural and human relations approaches that have already been explored in conflict resolution studies among academic deans. The analysis of conflict from the four dimensions is significant because it evaluates both leadership and managerial effectiveness. Leadership effectiveness is demonstrated by the use of political and symbolic frames whereas managerial effectiveness is demonstrated by the use of structural and human resources frames (Bolman \& Deal, 1991a; Thompson, 2000).

\section{Limitations and Delimitations}

Limitations. The following limitations were recognized in this research:

1. The study pertained to academic deans in the colleges of Business and Education in the Public Masters Colleges and Universities-Larger program- institutions (Carnegie Classification, 2010) and hence may not be generalized to other administrators or other types of institutions.

2. The study adapted ROCI-II (Form B) instrument which indicates how administrators handle conflicts with their subordinates. Hence, the research did not evaluate superior or peer-related conflicts.

3. The study used self-report instruments; this could be a limitation because the deans may have biased their self-perceptions on leadership orientations and conflict management styles. However, according to research, the Leadership Orientation Instrument (Self 
version) (LOI-Self) and Rahim Organizational Conflict Inventory (ROCI-II) are reported to have high reliability and validity scores by various researchers: Bolman and Deal (1991b), the LOI-self instrument demonstrates high reliability with a Cronbach alpha of at least 0.91 in all the frames. In a similar way, the ROCI-II instrument has been commended for indicating low social desirability (Ben-Yoav \& Banai, 1992; Womack, 1988 ) and also its alpha-coefficients on self ratings are close to 0.80 which is higher than most other conflict management instruments.

4. The research was limited to identifying the correlation relationships between Bolman and Deal's four-frame leadership theory and Rahim's five conflict management styles and hence, it does not suggest a causation relationship between the variables.

5. The study assumed that the identified leadership frames, styles, and conflict management styles were the deans' pre-disposed orientations at the time of research and hence, does not suggest that the revealed dispositions are stable across time.

6. The study recognizes the limitations associated with collecting data using survey research. This is determined to be a limitation because more information that could be extracted using the interview process was not collected; moreover, studies that measure respondent' attitudes and behaviors are difficult to observe and control as would be in an experimental research. However, the researcher made all possible attempts to ensure that the research findings are a true representation of the leadership orientations and conflict management styles of academic deans heading Business and Education colleges in public Masters Colleges and Universities- Larger programs- institutions.

Delimitations. The following delimitations were constrained in this study to ensure that the research pertained to a central focus. 
1. The first delimitation was the Carnegie classification of the selected institutions. This study focused on Masters Colleges and Universities- Larger programs. These refer to institutions which grant more than 200 masters degrees, but less than 20 doctoral degrees, in a year. To further narrow the scope of the research; public institutions in this classification were considered. The researcher found it necessary to delimit the type of institution to ensure uniformity in mission and goals. .

2. The second delimitation was the choice of colleges in the study. The study investigated academic deans in Business and Education colleges because majority of the colleges in Master's degree institutions offered those two disciplines and the offering in the two colleges do not overlap.

3. The third delimitation was the choice of the leadership orientation and conflict management instruments. The two instruments were used co-currently because they both recognize the effect of a person's predisposition or orientation in the choice of a leadership frame and conflict management style. To add to that, the ROCI-II (form B) instrument, which evaluates respondents' conflict management styles with their subordinates, was used in this study because academic deans have a leadership responsibility to manage conflicts with their subordinates who would be department chairpersons and other faculty members.

4. The fourth delimitation was made in the sampling of deans. The researcher obtained the list of the deans and their contact information from the Higher education publication, incorporated (2010) - the corporation compiles and sells customized databases of educational personnel for research purposes- this directory was used because it offers comprehensive information on all higher education personnel. However, the study was 
limited only to the academic deans whom their contact information was uploaded in the directory at the time of the research.

\section{Terms and Definitions}

The following terms are defined to assist in understanding the research study.

1. Masters colleges and universities (larger programs) - This includes institutions that award at least 200 masters degrees and fewer than 20 doctoral degrees per year (Carnegie Classification, 2010).

2. College or schools of Business- Colleges considered in the study were those in business, commerce, or management irrespective of the minor field. Hence they included colleges of Business Administration, Business and Technology, Business and Applied Sciences, Business and Computer Science, Business and Economics among others; colleges that combined schools of business and education were not considered to avoid overlaps.

3. College or schools of Education- Colleges considered in the study were those in education irrespective of the minor field. Hence they included colleges of Education and Allied Studies; Education and Integrative Studies; Education and Human Development; Education and Professional Studies; Teacher Education among others.

4. Academic deans- Administrative officers in charge of a college in a university. They oversee the operation of various discipline areas in colleges and report to the chief academic officers in their institutions (Cantu, 1997).

5. Conflict- The exercise of power by two or more parties in an attempt to attain mutually incompatible goals (Fink, 1968). It can occur when individuals differ in their interpretation of facts because of differences in their perceptions (Fisher, et al., 1991). 
6. Conflict management- The steps that disputants take to attain a moderate level of conflict. It does not imply the total elimination or reduction of conflict; moderate levels of conflict can be attained by reducing it if it is too much, or enabling it if it is too little (Rahim, 1985). The current study focused on conflict management.

7. Cognitive frame- This refer to the mental structures that facilitate the organizing and interpreting of incoming perceptual information by fitting it into already learned schema's or frames about reality (Dewulf, et al., 2009, p.158).

8. Leadership frame- This refer to the mental structure that leaders possess that enable them to interpret incoming perceptual information about any situation, organize the information and make decisions based on their co-constructed reality ( Dewulf, et al., 2009).

9. Conflict frames- These refer to the lenses through which disputants view a conflict situation. They determine the aspect of conflict to be addressed and those to be ignored (Pinkley \& Northcraft, 1994).

10. Leadership style- This refer to the pattern of leadership frame and frame choices perceived to be used by the study participants as determined by a mean score of 4.0 or greater on the leadership orientation survey by Bolman and Deal (Bolman \& Deal, 1997).

11. No frame leadership style- No dominant leadership frame of the four frames of leadership is demonstrated by the study participant. The participant scores a mean score of less than 4.0 on all the items in the four frames (Bolman \& Deal, 1997).

12. Single frame- This refer to the frequent use of one leadership frame of the four possible frames as determined by a study participant's mean score of 4.0 or greater on items in 
that frame as determined by the leadership orientation survey by Bolman and Deal (Bolman \& Deal, 1997).

13. Paired frame- This refer to the frequent use of two leadership frames of the four possible frames as determined by a study participant's mean score of 4.0 or greater on items in any two frames of leadership as determined by the leadership orientation survey by Bolman and Deal (Bolman \& Deal, 1997).

14. Multi-frame- This refer to the frequent use of the combination of three or more leadership frames by a study participant as reflected by a mean score of 4.0 or greater on items in three or more frames of leadership (Bolman \& Deal, 1997).

15. Structural frame- This is the leadership perspective that focuses on formal roles, chains of command, responsibilities, policies, and goals (Bolman \& Deal, 1997).

16. Human resource frame- This refers to the leadership perspective that focus on people. Leaders exhibiting this frame aim at fulfilling their employee human needs and enhancing relationships within the organization (Bolman \& Deal, 1997).

17. Political frame- This leadership frame emphasizes on building power-bases, coalition building, negotiating conflict over limited resources, and creating compromises (Bolman \& Deal, 1997).

18. Symbolic frame- This leadership frame emphasizes on creating a vision and inspiration among members of the organization. It is characterized by rituals, ceremonies, traditions all aimed at giving meaning and interpretation of the organization's work (Bolman \& Deal, 1997). 
19. Leadership Orientation Instrument (LOI-Self) - This is an instrument developed by Bolman and Deal to evaluate leaders' leadership orientations and it is made up of 32 questions.

20. Rahim Organizational Conflict Inventory- II (form B) (ROCI-II) - This is an instrument developed by Rahim to measure leaders' conflict management styles with their subordinates; it is made up of 28 questions (Rahim, 1983).

21. Integrating conflict management style- This style is concerned with collaborations between parties to reach a solution during a conflict situation. The disputant has a high concern for self as well as the other party involved in the conflict (Weider-Hatfield, 1988).

22. Obliging conflict management style- The disputant has low concern for self and high concern for other party involved in the conflict. Disputants attempt to de-emphasize the differences and accentuate the commonalities to satisfy the concerns of the other party (Weider-Hatfield, 1988).

23. Avoiding conflict management style- The disputant has low concern for self as well as the other party. It is associated with withdrawal, passing -the -buck, sidestepping, or "see no evil, speak no evil” (Weider-Hatfield, 1988).

24. Dominating conflict management style- The disputant has high concern for self and low concern for the other party. It adopts a win-lose orientation (Weider-Hatfield, 1988).

25. Compromising conflict management style- The disputant negotiates for a middle ground with the other party so that no one wins or losses (Weider-Hatfield, 1988). 


\section{Chapter II}

\section{Literature Review}

This chapter reviews the concept of leadership and conflict management as they pertain to the roles of the academic dean. More specifically the literature will address: Concept of leadership; leadership theories; conflict management theories; sources and stages of conflict; conflict management styles; perspectives of conflict management in higher education; and finally the academic dean.

\section{Concept of Leadership}

Leadership is a topic that has interested both scholars and laymen for generations because of its influence on everyone's life (Yulk, 1981). Although the concept is age-old, attention to scientific leadership studies began in the $20^{\text {th }}$ century as a result of developments in psychometrical measurements' of the 1920's that aimed to identify the specific traits that made one an effective leader (Kreitner \& Kinicki, 1989; Yulk, 1981). The term leadership has as many definitions as the number of people who have attempted to define it (Yulk, 1981) and various scholars have offered a set of principles to explain it (Allan, Gordon \& Iverson, 2006). Leadership is described in the context of a person's personality or behavior; as a mechanism to induce compliance; an exercise of influence; an interaction pattern; a form of persuasion; a power relation; an instrument to achieve goals; an occupation of an administrative position; and initiation of structure among other definitions (Bass, 1990; Yulk, 1981). It is a multifaceted element and its definition depends on the purpose of the researcher (Yulk, 1981).

According to Kreitner and Kinicki (1989) leadership is the "social-influence process in which the leader seeks the voluntary participation of subordinates in an effort to reach 
organizational objectives" (p.447). Robbins (1996) defined it as the "ability to influence a group toward achievement of goals" (p.413); Hersey, Blanchard and Johnson (1996) stated that "leadership is the activity of influencing people to strive willingly for group objectives" (p.90). All the definitions recognize that leadership involves an interaction between two or more persons and it entails the process of influencing followers to achieve organizational goals willingly (Hersey et al., 1996; Kreitner \& Kinicki, 1989). According to Kreitner and Kinicki (1989) the process of leadership is voluntary because it entails more than having power or authority. Hence, leadership is distinguished from management because unlike the latter, it influences followers to achieve organizational goals irrespective of formal authority (Robbins, 1996). Drucker (1999) concluded that management involves doing things right; whereas, leadership entails doing the right things.

\section{Leadership Theories}

Various models have been developed to define what constitutes a good leader. There are six theories of leadership: Traits, behavioral, situational, power and influence and lately the cognitive theories and culture and symbolic theories.

Traits theory. The traits approach was the earliest leadership model. It assumed that leadership was an intrinsic element and that some people were endowed with specific leadership traits that were not possessed by other people (Yulk, 1981). Although researchers postulated the traits that made one a leader, increased interest to identify specific traits that distinguished leaders from non leaders (Bensimon, Neumann, \& Birnbaum, 2000; Kreitner \& Kinicki, 1989; Robbins, 1996; Yulk, 1981) were reinforced by the development of empirical testing between 1920 and 1950 (Yulk, 1981). These early studies found that leaders had specific physical characteristics in regard to height, appearance, and energy levels; they had high self-esteem, 
emotional stability, and dominating personality; they also demonstrated competence in general intelligence, verbal fluency, originality, and social insight (Kreitner \& Kinicki, 1989; Yulk, 1981). Studies on leadership research advanced from distinguishing leaders from non-leaders to comparing successful leaders with the less successful. Success in leadership was measured through group performance and personal career advancement (Yulk, 1981). Ralph Stogdill in 1948 examined the results of 124 traits studied from 1904 and 1948 and found that successful leaders had the following five qualities: Intelligence, self-confidence, high level of energy and activity, and had task-relevant knowledge (Kreitner \& Kinicki, 1989; Yulk, 1981). Although these innate abilities were believed to be transferable from one situation to another (Hersey, et al., 1996); Stogdill found that a person's leadership effectiveness varied with situations. Hence, the exclusive possession of the traits and personal characteristics by the leader did not ensure leadership; leadership effectiveness was influenced by the characteristics, activities, and goals of the followers (Yulk, 1981).

To advance leadership effectiveness studies, Richard Mann in 1959 found that out of the five leadership traits evaluated by Stogdill; intelligence was the only trait that best predicted leader effectiveness. The other traits had positive but weak correlations with leader effectiveness. This was a great limitation to the traits theory because, unlike past beliefs, the study found that the possession of leadership qualities did not endorse one to be a leader (Kreitner \& Kinicki, 1989). Despite these criticisms, the traits approach is regaining attention (Hersey, et al., 1996; Kreitner \& Kinicki, 1989; Robbins, 1996) with new studies showing that there are some specific characteristics that distinguish successful leaders.

Warren Bennis did a five-year study to identify traits of successful leaders. He studied 90 successful leaders and found that they had four specific leadership traits: Management of 
attention-the ability to influence followers toward a common goal or vision; management of meaning- leaders' ability to communicate the vision of the organization clearly to its constituents; management of trust-leaders' ability to develop mutual respect and faith among the followers; and management of self- leaders' ability to self-analyze, accentuate, and capitalize on their strengths (Hersey et al., 1996; Kreitner \& Kinicki, 1989). A second study by Stogdill in 1974 reviewed 163 trait studies conducted between 1949 and 1970 and found some specific traits and skills displayed by successful leaders. Successful leaders were adaptable to situations, alert to their social environment, ambitious and achievement oriented, assertive, cooperative, decisive, dependable, dominant, energetic, persistent, self-confident, had high tolerance to stress and were willing to assume responsibility. The study also found that they were intelligent, creative, diplomatic, organized, persuasive, socially skilled, verbally fluent, and were knowledgeable about group tasks (Yulk, 1981).

Although traits play a vital role in how leaders are perceived (Kreitner \& Kinicki, 1989), the theory is limited because more often than not, the effectiveness of a leader depends on the situation: traits in one situation may not be effective in another and two different traits may be effective in the same situation. The theory also ignores the role of the followers and it does not offer opportunities for leadership training. Hence this prompted the development of behavioral theories.

Behavioral theories. Research on behavioral leadership theories began during the World War II as a strategy to prepare military leaders and as an expansion of the human relations movement (Kreitner \& Kinicki, 1989). Unlike the traits theory, the behavioral leadership theories regard leader effectiveness to be as a result of leaders' behavior rather than their personality traits (Kreitner \& Kinicki, 1989; Mosser \& Walls, 2002). The theory acknowledges 
the role of a leader's behavior on work-group effectiveness and asserts that leaders can display different patterns of behavior to influence the achievement of organizational goals. It also affirms that there is one best leadership style and that leaders can be trained to achieve it (Kreitner \& Kinicki, 1989).

Studies on behavioral leadership began in Ohio State and at the University of Michigan in 1945. The Ohio State studies obtained 1,800 statements that described nine categories of leader behavior and identified two independent dimensions of leader behavior: Initiating structure and consideration. The behavioral studies adopted the Leader Behavior Description Questionnaire (LBDQ) to identify the dimensions of leader behavior. Leaders considered to employ the initiating-structure leader behavior were regarded as task-oriented and they were concerned with directing subordinates, clarifying subordinate's roles, planning, problem solving, and coordinating organizational tasks; whereas leaders considered to apply the consideration dimension were regarded as people-oriented and they were perceived to be supportive, friendly, considerate, and had open communication with their employees. Although researchers hypothesized high consideration and high initiating-structure leader behaviors to be the optimal combination for effective leadership, different studies have yielded mixed results (Kreitner \& Kinicki, 1989; Yulk, 1981).

At the University of Michigan a study similar to the Ohio State yielded comparable results. Corresponding to the initiating structure dimension was the production oriented perspective; whereas the consideration dimension was referred to as employee orientation (Hersey, et al., 1996; Kreitner \& Kinicki, 1989; Robbins, 1996). The research at the University of Michigan focused on identifying the relationships among leader behavior, group processes, and measures of group performance. The study found that effective leaders were both task and 
employee related. They observed that effective leaders concentrated on supervisory work such as planning, scheduling, and coordinating whilst allowing the subordinates some autonomy in their work (Yulk, 1981). These two studies- Ohio State and University of Michigan are the backbone of all behavioral leadership theories.

Following these two main studies, various theorists have proposed different taxonomies to explain leader behavior. Halpin and Winer (1957) did a factor analysis, on the responses of the LBDQ questionnaire administered, to 300 air crew members and found that there were four separate factors depicting leader behavior: Consideration, initiating structure, production emphasis and sensitivity. Corresponding to this taxonomy; Likert (1961) integrated the Michigan studies findings and proposed four managerial practices for effective leadership: supportive behavior, group method of supervision, high performance goals and linking pin functions. Likert recommended that the managerial practices compliment the technical functions. In 1966, Bowers and Seashore re-conceptualized the Michigan and Ohio State studies and proposed a theory that explained managerial effectiveness in four categories of leadership behavior: Support, interaction facilitation, goal emphasis, and work facilitation (Yulk, 1981). Unlike the traits theory, the behavioral theories recognize that leadership functions can be carried out by both the supervisors and the subordinates. Bowers and Seashore's main contribution was the development of a parallel questionnaire that measured both supervisor's and subordinate's leadership behavior. The theorist emphasized the need to measure both subordinate and manager behavior illustrating that leadership functions can be performed by either party (Yulk, 1981)

In 1964, Robert Blake and Jane Mouton developed the managerial grid which is a matrix formed by the intersection of the two dimensions of leader behavior: Concern for production and concern for people (Blake \& Mouton, 1978; Kreitner \& Kinicki, 1989). By scaling the two 
dimensions on a grid of one to nine; Blake and Mouton identified five specific management styles: Impoverished management, authority-obedience, organization-man management, country club management, and team management styles (Hersey, et al., 1996; Kreitner \& Kinicki, 1989). The team management leadership style is considered to be the one best style of leadership (Blake \& Mouton, 1978) (see Figure 1).

Although the behavioral leadership theories acknowledge that leaders can also be trained; they are criticized for justifying only one leadership behavior. Situational theorists argue that the one-best-style approach is oblivious of other situational factors that influence leader effectiveness (Kreitner \& Kinicki, 1989).

Situational theories. These theories were developed to counter the assumption that there is one best style of leadership for all situations. They advance that leadership effectiveness is contingent on the situation; as situations change different styles become appropriate (Kreitner \& Kinicki, 1989). Various studies have been done to isolate specific situational factors that affect leadership effectiveness. Fiedler's contingency model believed that leadership effectiveness was contingent to degree of task structure, leader-member relations, and the position power of the leader. Fiedler developed the least preferred co-worker (LPC) questionnaire to identify if the leader was task or relationship oriented (Hersey et al., 1996; Kreitner \& Kinicki, 1989; Robbins, 1996). Co-workers who had low ratings on the LPC questionnaire were thought to be taskoriented whereas those who scored high ratings were thought to be relationship-oriented. This theory recognized leadership styles to be stable across situations as they portray the person's basic motivation (Kreitner \& Kinicki, 1989). 
Figure 1. Blake and Mouton's Managerial Grid

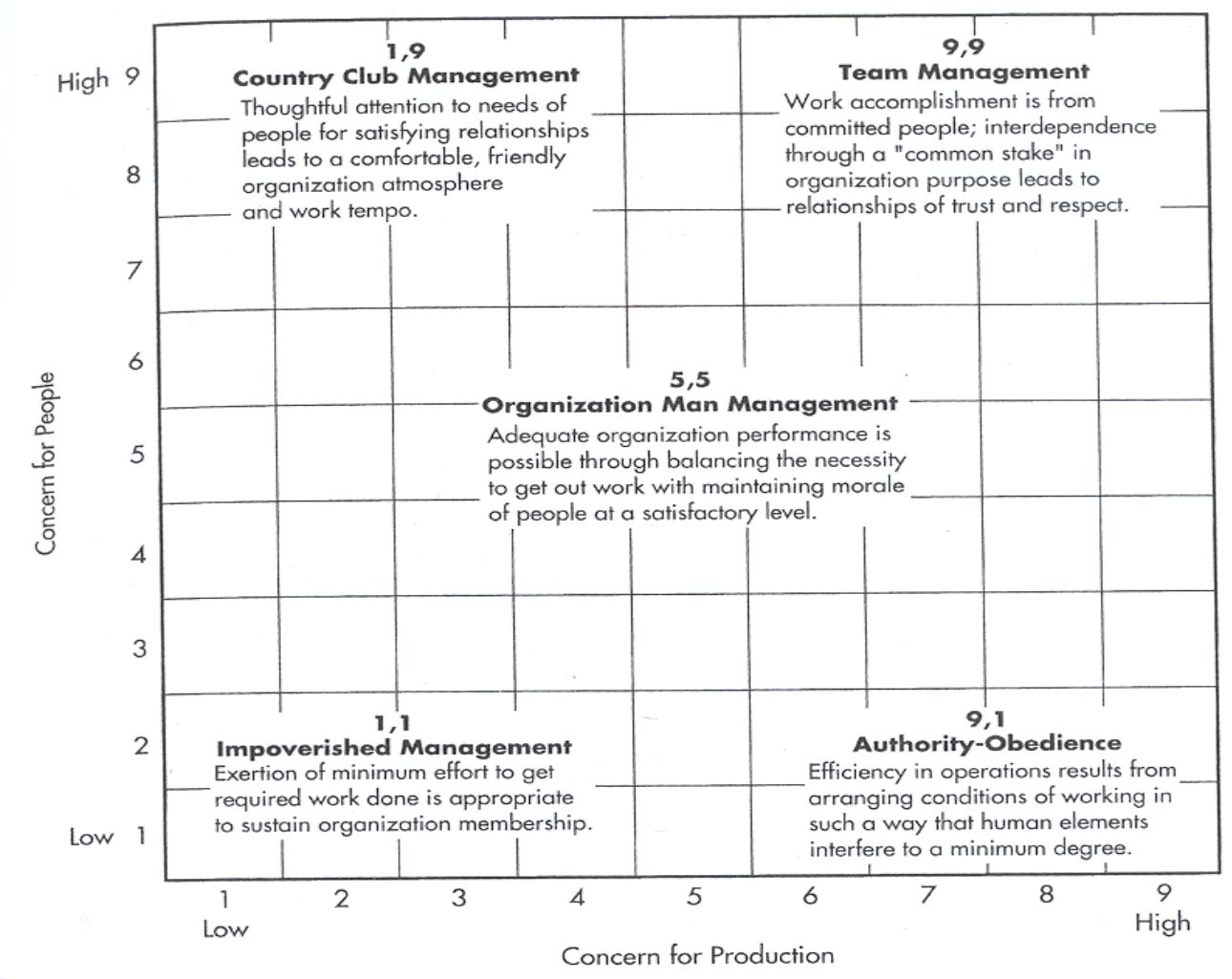

Figure 1: Represents the five management styles developed on a scale of one to nine indicating the extent to which a manager has concern for people or production. Adapted from "The Managerial Grid III: A new look at the classics that has boosted productivity and profits for thousands of corporations worldwide" by R. R. Blake and J.S Mouton, 1985, (p.12) Houston London, Copyright 1985 by Gulf Publishing Company. Adapted with permission (see footnote $1)$. 
In 1987, Fielder and associate Joe Garcia re-conceptualized the theory to cognitive resource theory in which they integrated the role of experience, tenure, and intelligence in explaining leadership effectiveness. The theory assumed that in non-stressful situations, the intellectual abilities of the leader correlated positively with group performance whereas in stressful situations, performance was positively correlated to experience (Robbins, 1996; Russell, 2000).

The second contingency theory was Hersey and Blanchard's situational theory which focused on the readiness and maturity of the followers as a predictor of leadership effectiveness (Robbins, 1996). Follower maturity is defined as the "capacity to set high but attainable goals" (p.140) whereas follower readiness refers to their willingness to take responsibility. The theory recognizes the need for job and psychological maturity as predictor variables of leadership effectiveness. They assert that subordinates need the task-relevant skills as well as feelings of self-confidence and self-respect to attain organizational goals (Yulk, 1981). Leaders employ a telling, selling, participative, or delegating behavior depending on the follower readiness and ability to achieve organizational goals (Robbins, 1996) (see Figure 2).

Contrary to Hersey and Blanchard's situational theory, George Graen developed the leader-member exchange theory that focused on the role of the leader in determining follower effectiveness in reaching organizational objectives. The study found that leaders formed special, one-on-one relationships with their subordinates that determined if the subordinate is in the ingroup or out-group of the leader's clique. Subordinates who belonged to the in-group reported high performance ratings, had less turn-over, and had greater satisfaction with their supervisor and organization than those in the out-group. 
Figure2. Situational Leadership Model

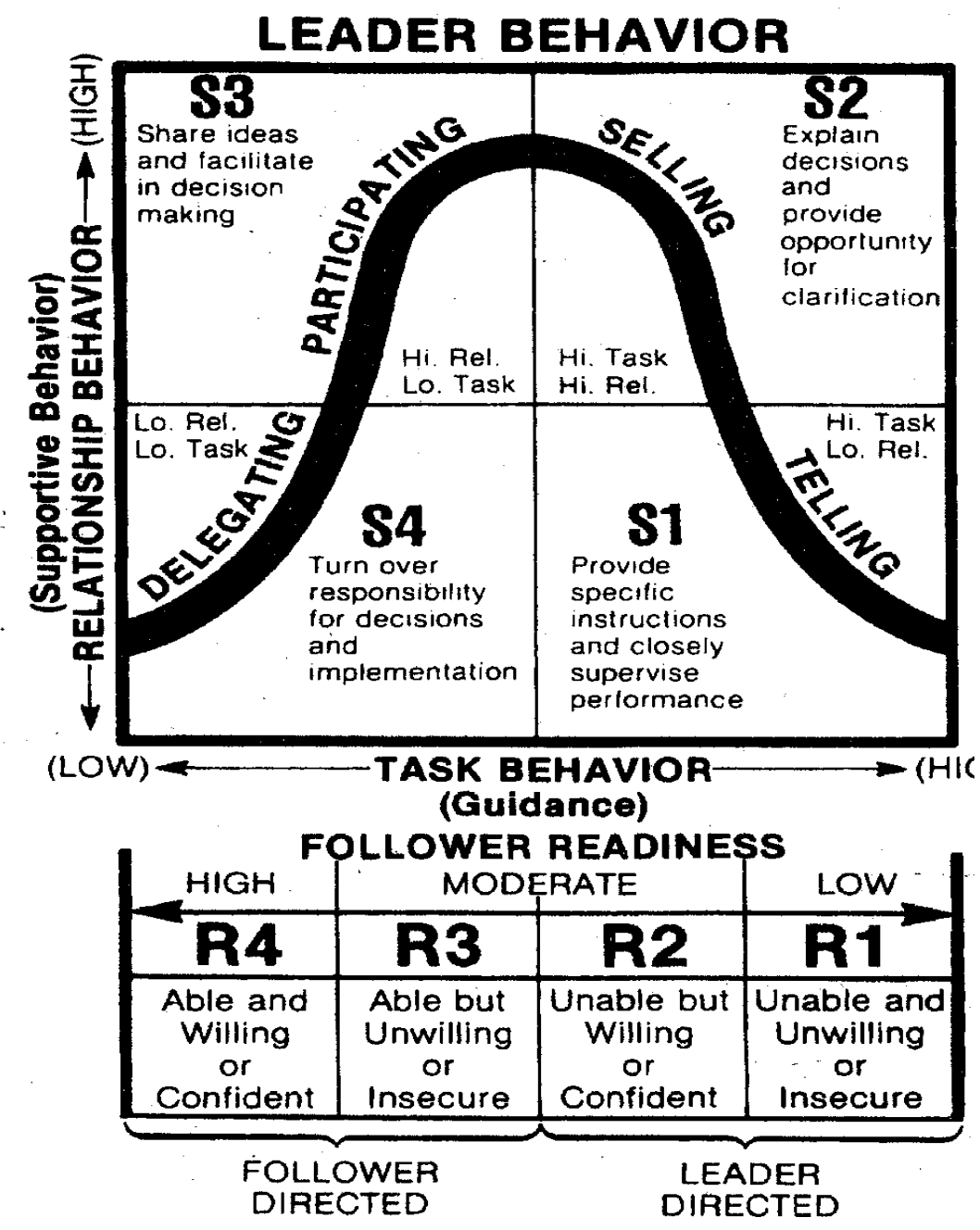

Figure 2. Situational leadership model illustrating a leader behavior in the context of follower readiness and maturity. Adapted from "Management of Organizatonal Behavior: Utilizing Human Resources," by P. Hersey, K.H. Blanchard, and D. E. Johnson, 1996, (p. 208). Copyright 1996 by Prentice Hall Inc. Adapted with permission (see footnote 2). 
To advance the Blanchard's situational theory and George Graen's leader-member exchange theory; Robert House developed the path-goal theory which identifies the role of the leader in influencing follower's expectation (Kreitner \& Kinicki, 1989). This theory recognized leadership functions as providing direction, guidance, and support to the followers in an effort to increase employee performance and ultimately organizational goals. House developed four leadership styles: Directive leadership, supportive leadership, participative leadership, and achievement-oriented leadership (Robbins, 1996). The theory makes the assumption that subordinates perceive the leader- behavior to be motivational to the degree to which the leader reduces barriers to goal achievement and provides guidance and support to the followers. Hence an effective leader is identified as one who ties rewards to goal achievement and guides the constituents toward achieving them (Kreitner \& Kinicki, 1989).

The fifth contingency model is the Vroom and Yetton's leader participation model also known as the decision-making model and it was developed in 1973. The model is prescriptive in nature and it describes the appropriate decision-making styles a leader can adopt for various situations. Vroom and Yetton identified five decision-making styles along the dimensions of autocratic and participative situations (Kreitner \& Kinicki, 1989). Leaders can adopt autocratic, consultative, or group decision making depending on how they respond to the seven dichotomous questions provided by Vroom and Yetton. Similar to the Path-Goal theory, the model assumes that leadership styles are flexible and that a leader can adjust their leadership styles to suit either the autocratic or participative situations (Robbins, 1996). The contingency variables considered in the model are: Quality of decision, subordinate's commitment to decision, availability of information, problem structure, goal congruence, subordinate conflict, time constraints, and geographical dispersion (Hersey et al., 1996; Robbins, 1996). The theory 
affirms that leadership research should be directed to the situation and not to the person; hence allowing for leadership training. Although the decision-making model is credited for helping managers choose the most appropriate leadership style depending on the situation, it is limited because it assumes that all administrative situations are clear cut with "yes" or "no" answers which is not always the case. It is also criticized for its complexity and sophistication in practice and its validity has not been assessed (Kreitner \& Kinicki, 1987; Robbins, 1996).

The contingency theories have been commended for their ability to explain leadership in the context of situations; nonetheless, they have been criticized for failure to distinguish leadership and management. Most of the theories also have limited research and the validity of their models is untested (Bolman \& Deal, 1991).

Power and influence theories. Power and influence theories have been divided into two distinct theories: Social-power theory (transformational leadership theory) and social-exchange theory (Transactional leadership theory). These theories refer to the influence process that leaders have over their followers (Bensimon, et al., 2000). Although leaders can use power to attain group goals, leadership and power are not synonymous. Leadership refers to the ability to influence followers to attain a common goal; whereas power refers to the use of "human, information, and material resources" (Kreitner \& Kinicki, 1989, p.370) to attain compliance. Hence, whereas leadership requires goal compatibility, the main requirement in the use of power is dependency. The person in power must perceive their ability to control something of value to influence the behavior of the other party (Robbins, 1996). French and Raven identified five sources of power: Coercive power, reward power, legitimate power, expert power, and referent power. Coercive power refers to the ability to use threats and punishment to achieve compliance; reward power is attained when leaders use rewards perceived to be of value as a 
way of compensating behavior; legitimate power refers to the ability to influence behavior through the use of hierarchical or formal position; expert power refers to the ability to attain influence because of one's expertise, special skill or knowledge; finally, referent power refer to the power that once achieves because of their personality(Guidry, 2007; Kreitner \& Kinicki, 1989; Robbins, 1996).

Bass (1990) recognized that few managers use legitimate or coercive powers to influence their followers; rather, leadership is a transactional process between managers and employees. Burns (1978) defined it as a process in which "leaders approach followers with an eye to exchanging one thing for another" (p.4). Transactional leadership style is therefore considered a two-way process involving mutual influence and reciprocal relationships (Bensimon, et al., 2000). It emerges from behavioral and contingency theories such as Ohio state studies, Fielder's contingency theory, the path-goal theory and it illustrates the role of the leader as providing guidance and motivation to followers with an aim to accomplish organizational goals (Robbins, 1996). A study done at Xerox Reprographic Business Group found that out of the 44 specific effective management practices identified, managers and employees were engaged in transaction or exchange process in which good performance was rewarded and poor performance punished. This is the essence of transactional leadership. Despite leadership emerging as a transactional process; the transactional leadership style is considered a "prescription for mediocrity" (Bass, 1990, p.20) because the rewards or punishment presented act as a motivation only if the employees value or are concerned about them. Contrary to transactional leadership, transformational leadership is a one-way leadership process in which the leader has a role to influence the activities of others through creating and promoting a common vision and image of the organization (Bensimon, et al., 2000). 
Burns (1978) defined a transformational leader as one who "recognizes and exploits an existing need or demand of a potential follower" (p.4). Burns likened transformational leadership with exceptional, heroic, or uncommon leadership in which the leader exerts both intellectual and moral leadership to influence followers toward a common vision. He identified leaders such as Lenin, Gadhi, and Mao as transformational leaders who influenced their nations out of political isolation to political participation. Transformational leaders use referent and expert powers rather than coercive, legitimate, or reward powers to influence their followers (Bensimon et al., 2000; Hersey, et al., 1996).

Although studies have shown the transformational theory to be more effective than the transactional theory; both theories are useful in understanding the interactions between leaders and followers (Bensimon, et al., 2000). A study done by Hendel, Fish and Galon (2005) on the relationship between the transformational and transactional leadership styles and the conflict resolution style among head nurses in Israel found that; most head nurses perceived themselves to be transformational rather than transactional leaders. However, from the study the leadership style explained only $20 \%$ of the variance in the choice of a conflict management style illustrating that other factors other than the leadership style would be influencing the choice of a conflict management style among the head nurses.

Cultural and symbolic theories. Cultural and symbolic theories emerged in the early 1980's with the commencement of Ouchi's theory Z (1980); Pascale and Atho's “The art of Japanese management” (1981) and Deal and Kennedy’s corporate culture (1982). These Japanese management methods emphasize on the "soft" skills of management to supplement the strategic planning, marketing, and management principals applied in American institutions (Dill, 1982). Organizational culture has been defined as the "beliefs, ideologies, or dogma of a group 
which impel individual to action and give action meaning" (p.264). Consistent to this definition, symbols refer to "objects that serve as vehicles for conveying meaning" (Tierney, 1989). Hence the use of symbols and organizational culture are intertwined concepts that view the role of a leader as a "manager of meaning" (Dill, 1982; Russell, 2000).

The concept of culture has been studied from different perspectives: Geert Hofstede identified five dimensions of culture to measure cultural differences in international business: Power-distance, individualism, masculinity, uncertainty-avoidance and long term orientations. Power-distance dimension refer to the degree of power inequality between more powerful and less powerful members of a group. Countries with high power-inequality have accepted the unequal distribution of power and place highest concern on hierarchy. Managers in these work places display bureaucratic orientations and they adhere to hierarchy, rules, and centralized relationships. On contrary managers in countries with low power-inequality; have more participative leadership orientation because power is shared and distributed among the people (Hofstede, 1984).

Individualism dimension refer to the extent to which people view themselves as individuals or as a group. Communities with high individualism have fewer ties with each other and they emphasis on autonomy and independence principles. On contrary societies with low individualism have integrative and cohesive groups and they emphasize on collective goals. Masculinity- feminine dimension refers to the division of roles based on gender. The society determines the values that men and women hold depending on the societal expectations. In masculine societies, masculine traits such as assertiveness, competition, and materialism are emphasized. In these societies, men place a lot of value in career success. On contrary, in 
feminine societies greater emphasize is placed on moral issues, compassion, and compromise values (Bolman \& Deal, 2003; Hofstede, 1984).

The uncertainty-avoidance cultural dimension refers to the extent to which people are tolerant of uncertainty and ambiguity. Countries with high uncertainty-avoidance culture place a lot of emphasis on structures, rules, safety and security measures and are more risk averse; on contrary, societies with low uncertainty -avoidance tendencies, put less emphasis on structure and are more risk-taking. Long-term orientation is the most recent of Hofstede's dimension and it focuses on the differences in values between countries. Countries with long-term orientations had the following characteristics: Persistence, observed hierarchy, thrift and had a sense of shame; whereas those with short term orientations had respect for traditions, reciprocated greetings, favors, and gifts and emphasized on personal steadiness and stability. The study found that China had the highest index of long term orientation; followed by Brazil and India (Bolman \& Deal, 1991; Hofstede, 1984)

Edgar Schein a scholar in the school of management identified three levels of organizational culture: Artifacts, espoused values, and basic assumptions and values (Kuh \& Whitt, 1988; Schein, 1992). Artifacts refer to aspects of an organization that can be observed (Schein, 1992). According to Kuh and Whitt (1988), evidence of organizational culture can be found in norms, formal and informal rules, ceremonies, rituals, rites, stories, and myths and they all signify the principles of an institution. Espoused values refer to the conscious strategies, goals and philosophies practiced by an institution (Schein, 1992) as noted by Kuh and Whitt (1988) institutions of higher learning hold the values of justice, competence, liberty, and loyalty and portray them through adherence to academic freedom and tradition of collegial governance to signify institutional values. Finally, basic assumptions and values refer to the beliefs that guide 
behavior; they determine how reality is perceived. They are conceived sub-consciously and reveal the basic assumptions and values of an institution. In institutions of higher learning these can be revealed through observing the rituals and ceremonies of the institution and talking to students and faculty with an aim to disclose their values (Kuh \& Whitt, 1988).

Studies have been done on cultural and symbolic theories of leadership in higher education: Organizational culture in the higher education (Masland, 1985); culture in American colleges and universities (Kuh \& Whitt, 1988); understanding academic culture and climate (Peterson and Spencer 1990); symbolism and presidential leadership (Tierney, 1989); and the management of academic culture (Dill, 1982) among others.

Masland (1985) identified four windows of organizational culture as sagas, heroes, symbols and rituals. A saga refers to unique organizational elements that set an institution apart from the others. In this case the use of a mission statement in a college setting could signify a saga. Heroes refer to important people in the organization; for instance, a college founder could represent the hero of the college. Symbols are defined as the metaphors that help in understanding organizational culture. According to a study done by Tierney (1989), most college presidents use metaphors to describe their roles. Some presidents used analogous terms such as "I am militaristic" to describe their leadership styles; whereas teaching award ceremonies was used as an example of a ritual that signifies an institution's concern for teaching values (Masland,1985).

Cognitive theories. The cognitive theories are comparable to the cultural and symbolic theories because they conceptualize leadership as emerging from social constructs. These theories emphasize on the leader's self-perceptions and the follower's perception of a leader's ability (Guidry, 2007; Russell, 2000). According to Dewulf et al. (2009) cognitive studies have 
contributed significantly to the knowledge about frames as mind receptors that shape or limit our understanding about an issue. They are the mental processes that determine how people perceive and make judgment of the situations (Kreitner \& Kinicki, 1989).

Bolman and Deal leadership frames. According to Fairhurst (2005) framing is the "ability to shape the meaning of a subject, to judge its character and significance by choosing one particular set of meaning over another and asserting that the chosen interpretation be taken as real over other possible interpretations" (p.168). The concept of framing has a long and rich history in the social sciences, anthropology, sociology and it has received a lot of attention lately in leadership and management (Dewulf, et al., 2009). According to Bolman and Deal (2003), leadership frames are the mental structures that leaders possess that enable them to interpret incoming perceptual information about any situation, organize the information, and make decision based on their co-constructed reality. Leaders obtain the mental lenses from early experiences, heritage, education, and job training (Bolman \& Deal, 1991b). Bolman and Deal consolidated major schools of organizational thought into four perspectives which they labeled as frames referring to "windows, maps, tools, lenses, orientations, and perspectives" (Bolman \& Deal, 2003, p.12) that leaders use to understand their organizations. The four frames of leadership include the structural, human resources, symbolic, and political frames. A leader who uses multi-frame or balanced leadership orientation yields effective leadership (Bensimon, 1987; Bolman \& Deal, 2003; Thompson, 2000).

Structural frame. This frame reflects a belief in rationality and relies on formal arrangements to minimize problems and maximize performance (Allan, et al., 2006; Bolman \& Deal, 1997). It depicts institutions as factories engaged in the production process (Bolman \& Deal, 1992). The structural frame originates from the discipline of sociology (Bolman \& Deal, 
1991b) and it includes two main intellectual roots: The scientific management approach by Fredrick W. Taylor and the bureaucratic theory by Max Weber. The scientific management movement led to principles focused on specialization, span of control, authority, and delegation of responsibility. Alongside this, the Weber bureaucratic theory emphasize on fixed division of labor, hierarchy of office, set of rules to govern performance, technical qualifications for selecting personnel, and employment as a long-term career. These two theories contribute to the structural frame of leadership. The structural frame is most essential for understanding stable organization in which adherence to lines of authority is dominant. The role of the leader with a structural cognitive frame is to solve problems, get results, and establish systems of management (Bensimon, 1987; Bolman \& Deal, 2003).

Bolman and Deal (1992), in the study on images of leadership among school boards, found that most administrative and bureaucratic features of schools today have structural characteristics such as clear goals, rationality, specialization, accountability, and systematic evaluations. School board members take the leadership role of a technical expert when they provide knowledge, analysis, and expertise to their schools to ensure that they are run efficiently. Although the structural frame is apparent in schools, most school board members are repelled by the image of a school as a factory because they view students as "human and not mechanical gadgets" (p. 38).

Human relations frame. The human relations approach is built on the assumption that organizations exists to serve human needs and borrows from the fields of psychology and organizational behavior theories (Bolman \& Deal, 1991b, 1992). It equates organizations to an extended family made up of individuals with needs, feelings, prejudices, skills, and limitations (Bolman \& Deal, 1992) and organizational objectives are fulfilled through fulfilling those needs 
(Allan, et al., 2006). The frame borrows from the human relations movement by Elton Mayo, Abraham Maslow's theory of needs, and Douglas McGregor's theory X and Y.

The human relations movement was commenced in the 1920's and early 1930's and it argued that for an organization to increase its output; human needs had to be addressed (Hersey, et al., 1996). In 1943, Abraham Maslow developed the hierarchy of needs theory (Kreitner and Kinicki, 1989) that affirms that people are motivated by a variety of wants and organizations have a role to fulfill those needs as a means to meet their objectives (Bolman \& Deal, 1991). To add to these theories, in 1960, Douglas McGregor introduced theory X and Y. McGregor identified that although theory $\mathrm{X}$ perceived subordinates to be passive and lazy; theory $\mathrm{Y}$, on contrary, discerns a management with a role to arrange organization's conditions in such a way that people achieve their own goals by directing their efforts towards organizational goals (Bolman \& Deal, 2003). These principles are the primary foundation of the human relations approach. The frame is useful in understanding stable organizations in which constituents' preference is developed by consensus through interactions. Leaders who adopt this frame emphasize on participative and democratic decision-making (Bensimon, 1987).

Political frame. The political frame views organizations as "living, screaming, political arena's that host a complex web of individual and group interests" (p.188). It perceives organizations as coalitions of diverse interest-groups all competing for scarce resources (Bolman \& Deal, 2003). It borrows its ideas from political science and recognizes the role of conflict in the organization. The goals and decisions of the stakeholders emerge from bargaining and negotiations and the key element in the frame is the distribution and exercise of power. The frame emphasizes that goals are not set from the directives at the top but are as a result of the ongoing process of negotiations and interactions among key players. In this frame, leaders 
govern through persuasion and diplomacy; they encourage open communications; and are sensitive to external interest groups and their influence on the policy-making process (Allan, et al., 2006; Bensimon, 1987).

According to Bolman and Deal (1992), the school district is a coalition of different groups defined formally by organizational positions, race, ethnicity, or gender. The role of the school board is to advocate for education by providing clear directions and agenda, developing a network of allies and supporters and improving negotiation skills individually or collectively. The ethical responsibility of a school board in a political frame is to ensure justice.

Symbolic frame. The symbolic frame borrows from the cultural and symbolic theories and it recognizes organizations as highly complex with stakeholders who are in constant need to find meaning of the situations. It seeks to interpret and illuminate basic issues of meaning and beliefs that make symbols so powerful (Bolman \& Deal, 2003). This frame demonstrates the importance of framing and illustrates how different experiences and attitudes shape the meanings we confer to different situations. The symbolic frame further assumes that events have multiple meanings because people interpret experiences differently. In the face of uncertainty and ambiguity, people create symbols to "resolve confusion, increase predictability, find direction and anchor hope and faith" (p. 242).

Bolman and Deal (2003) affirm that "organizational culture is revealed and communicated most clearly through symbols" (p.246) and identified the five categories of symbolic aspects as myths, values and vision; heroes and heroines; rituals and ceremonies; and metaphors, humor and play. The myth, values and visions provide cohesion, clarity and direction in the presence of confusion and ambiguity in the organization; heroes and heroines act as role models for followers to emulate and look up to; rituals and ceremonies offer alternative 
ways for leaders to act during occasions of success and tragedy; and metaphors, humor and play are creative alternatives to structure and formality. Managers, who understand symbolic forms and encourage their use, shape their organizations by aligning the organizational culture with the challenges in the environment (Bensimon, 1987; Bolman \& Deal, 2003).

Various studies have been done to identify the use of the four frames by various higher education administrators. Most studies have been done on college presidents (Bensimon, 1987; Crist, 1999; Englet, 2008; McArdle, 2008; Monahan, 2004); department chairs (Chang, 2004; Griffin, 2005; Mosser \& Wall, 2002) and some on academic deans (Cantu, 1997; Guidry, 2007; Russell, 2000; Sypawka, 2008). A study by Bensimon (1987) found that of the 32 college and university presidents interviewed, 13 of them portrayed a single frame, 11 portrayed a paired frame, 8 portrayed a multiple frame, and only one president portrayed all the four frames. McArdle (2008) found that most college presidents espoused a human resource frame followed by the structural, political, and symbolic frames; on contrary, a study by Crist (1999) found that college presidents portrayed the structural and political frames more frequently followed by the symbolic and human resources frames. Nonetheless, all studies found significant differences between the new and experienced college presidents with more experienced presidents demonstrating paired or multi-frame leadership orientations more frequently that the new presidents.

Studies on the leadership orientations of chairpersons show that most chairpersons espouse a human resource orientation followed by the structural orientation (Chang, 2004; Mosser \& Walls, 2002). However, there were differences in the use of symbolic and political frames; a study by Mosser and Walls (2002) found that chairpersons were more likely to use the symbolic frame more than the political frame on contrary, Chang (2004) found that very few 
department chairs used the symbolic frame. Studies done on dean's leadership orientation also found that the most common leadership style among academic deans was the human resources frame (Cantu, 1997; Russell, 2000; Sypawka, 2008). Russell (2000) found that deans who had a multi-frame leadership orientation reported lower levels of levels of stress, higher work satisfaction and had lower role-conflict than deans who were single- framed. Cantu (1997) also found that deans with a political orientation were perceived to be more effective than deans with other orientations; effective health profession deans adopted the political and symbolic frames than effective science oriented deans.

Bolman and Deal (1991a) did a quantitative and a qualitative study on three different samples of education administrators: College presidents, vice-presidents, and deans. The study found that leaders hardly used more than two frames and almost no one used all the four frames. Of the three samples, college presidents were more likely to use the human resources and symbolic frames and least likely to use the structural frame. Bolman and Deal did a second study on 680 senior higher education administrators to identify if the four frames predicted leader or manager effectiveness. The study found that the four frames predicted $66 \%$ of variance in perceived managerial effectiveness and $74 \%$ in perceived leader effectiveness. Of the four frames, the structural frame was the best predictor of managerial effectiveness and worst predictor of leader effectiveness. The study also found that the symbolic frame was a direct opposite of the structural frame in that it was the best predictor of leader effectiveness and worst predictor of managerial effectiveness. Human resources and political frames had a positive and significant relationship with both leader and managerial effectiveness; however, the political frame was the best predictor of both leader and managerial effectiveness. 
Similar to the decision-making leadership model, the choice of a leadership frame involves the "combination of analysis, intuition, and artistry" (Bolman \& Deal, 2003, p. 309). Since some frames could be more useful in some situations more than others; leaders choose different frames depending on the situations. For instance, organizations operating in stable and certain environment, with clear goals, understandable technology, and reasonably predictable behavior are likely to have their leaders adopt a structural or human resource frame. However, as ambiguity increases and goals become unclear, the political and symbolic frames are likely to be more relevant. Similarly, highly profitable and growing organizations are likely to have their leaders espouse a collaborative strategy in case of conflict. However, as conflict increases and resources become scarce; dynamics of conflict, power, and self-interest emerge resulting to the vitality of political and symbolic frames (Bolman \& Deal, 2003).

\section{Conflict: General Overview}

Similar to leadership; conflict and conflict management is age-old. According to Burns (1978) philosophical interest in conflict was spurred by early western philosophers like Heraclitus, Thomas Hobbes, Niccolo Machiavelli, Georg Hegel, Karl Marx, and Sigmund Freud who recognized the role of conflict among personal relationship. Nevertheless, empirical Studies on conflict management in organizations began in the 1900's during the scientific management era (Kreitner \& Kinicki, 1989). Since 1900's up until 1930's and 1940's; classical theorists viewed conflict as an "undesirable phenomenon, symptomatic of improperly designed communication and reward systems" (p. 152); it was believed to produce inefficiencies and wellmanaged organizations were supposed to avoid it all together (Jones \& White, 1985). The advocates of this approach aimed at avoiding conflict through directing their attention to the causes of conflict and correcting the impairments so as to ensure group and organizational 
performance (Robbins, 1996). This traditional view of conflict gave way to the human relations approach which viewed conflict to be inevitable in the organizational life and had to be recognized and addressed (Jones \& White, 1985).

The human relations supporters argued that conflict was a natural phenomenon in all groups and organizations and advocated for its acceptance (Robbins, 1996). Although the human relations adherents supported the acceptance of conflict; they perceived it to be dysfunctional and organizations had a role to minimize or resolve it (Kreitner \& Kinicki, 1989). However the beginning of the 1970's saw the emergence of the interactionist view that not only accepted conflict, but also encouraged it on the position that it prevented organizations from becoming stagnant, sluggish, and unresponsive to change and innovations (Robbins, 1996). The emergence of social systems and open systems theory considered conflict as legitimate, inevitable and a positive indicator of effective organization management (Cetin \& Hacifazlioglo, 2004). Conflict has been argued to enhance creativity, increase rational decision-making, challenge old ideas, develop greater awareness to latent problems, and result to greater accuracy in re-framing issues. However, mismanaged conflicts can impair task effectiveness by retarding communication, reduce group cohesiveness, and cause in-fights among members (Cetin \& Hacifazlioglo, 2004; Jones \& White, 1985; Robbins, 1996; Wall \& Callister, 1995).

Conflict has been defined in a variety of ways: It is the exercise of power by two or more parties in an attempt to attain mutually incompatible goals (Fink, 1968); it occurs when one party blocks the goal attainment of another through direct intervention into the opponent's activities (Rapport, 1966); it can also occur when individuals differ objectively on the interpretation of some facts due to differences in their perception (Dewulf et al., 2009; Fisher, et al., 1991). Conflict is also defined as the process by which two or more parties perceive an opposition in 
goals, values, interests, or aspirations and aim at blocking their attainment (Deutsch, 1949; Thomas, 1992; Wall \& Callister, 1995). It can emerge from interpersonal factors such as communication problems, power struggles, or incompatible goals (Wall \& Callister, 1995).

Conflict and controversy in organizations are inevitable in the decision-making process and can take more $40 \%$ of an administrator's time (Stanley \& Algert, 2007). Unlike in the past when conflict was regarded as harmful to institutions; today's institutions view it as a natural and unavoidable circumstance which instead of being ignored or eliminated should be acknowledged and managed. Hence, there is need for administrators to acquire people-related skills such as negotiation, interpersonal communication, and conflict management skills to enhance the organization's job performance, job satisfaction, and reduce employee turnover (LandaGonzales, 2008).

Conflict can be analyzed from five distinct categories: Intra-personal conflict that occur within an individual because of conflicting value or belief systems; inter-personal conflict that occur as a result of goal incompatibility between two different individuals; intergroup conflicts that occur when two or more groups have incompatible goals between or among themselves; inter-organizational conflicts that occur between or among two or more organizations and international conflict that occur between or among nations (Jones \& White, 1985, Wall \& Callister, 1995).

Conflict studies have also been explored from the dimensions of functional and dysfunctional conflict, sources of conflict, conflict process, and conflict management strategies (Kreitner, 1980; Pondy, 1967; Rahim, 1985; Wall \& Callister, 1995). Conflict is viewed to be functional or dysfunctional depending on its intensity and management (Cetin \& Hacifazlioglo, 2004; Lovelace, Shapiro, \& Weingart, 2001; Robbins, 1996). Researchers have argued that 
functional conflicts are of moderate intensity and they can stimulate people toward greater work efforts, cooperation, and creativity (Cetin \& Hacifazlioglo, 2004; Rahim, 1985). On contrary, dysfunctional conflicts resulting from either too much or too little conflict may interfere with more task-relevant tasks and may encourage incompetency and loss of creativity (Rahim, 1985; Robbins, 1996). Hence the role of the manager is to manage conflict rather than reduce, resolve, or eliminate it; this is because if the amount of conflict is too little or nonexistent, organizations are likely to stagnate (Rahim, 1985).

The focus of this study was conflict management rather than conflict resolution since most conflict situations are very complex making it difficult to attain win-win outcomes (Stanley \& Algert, 2007).

Sources of conflict. According to Kreitner (1980) there are eight sources of organizational interpersonal conflict: Ambiguous goals; competition for scarce resources; communication breakdown; time pressures; inconsistent standards, rules, policies or procedures; personality clashes; unrealized expectation and incongruent roles. Woodtli (1987) found that nursing deans perceived the greatest source of conflict to emerge from faculty workloads and issues related to faculty compliance with unit expectations. On contrary, Olsen (1986) found that deans perceived budget allocations to be the greatest source of conflict; whereas personnel and curriculum matters were observed to be the least sources of conflict.

Wall and Callister (1995) grouped the sources of conflict into three major groups: Individual characteristics, interpersonal factors, and issues. Studies have shown that different personalities encounter conflict more frequently than others and some societal values can determine a person's attitude toward conflict. According to Robbins (1996) individuals with high authoritarian and dogmatic personalities are likely to demonstrate low self-esteem and have 
higher chances of encountering conflict. Wall and Callister (1995) also explain that, differences in individual goals and sub-unit goals can be a significant source of conflict; if parties have different levels of commitment to the goals. Comparable to goal divergence, Robbins (1996) recognized structures to be a potential source of conflict if groups are closely associated and that the more participatory a group was, the greater the chances of conflict. A negative relationship was also found between the length of tenure and amount of conflict. Similarly, young group members were more likely to encounter conflicts more than older members.

Interpersonal factors are cited as sources of conflict if there are communication breakdowns, negative interpretation of the other parties' intentions, efforts to sabotage other parties' goals, and power struggles within the relationships (Wall \& Callister, 1995). Robbins (1996) however, asserts that poor communication is not the source of conflict rather the problem is the communicating process that acts to retard collaboration and stimulate misunderstanding. He identified insufficient exchange of information; noise in communication channels; divergence of communication channels; and semantic difficulties in communication that result from selective perception, differences in training, and inadequate information to be potential causes of conflict. Studies confirm communication to be functional to some level as too much or too little of it can be a potential source of conflict.

According to Wall and Callister (1995) issues can be a source of conflict depending on their complexity, clarity, magnitude, and temperament. Complex issues are more likely to stir conflict than simple issues because of their likelihood to generate misunderstandings and expose disagreements. Similarly, vague concerns are likely to cause conflict more than clear issues. Also, issues that spur emotional agitation are likely to be more conflictive than issues that are authentic in nature. 
Stages of conflicts. Conflict is described by Pondy (1967) as a dynamic process involving a sequence of conflict episodes. Each conflict incident sets a precedence of subsequent conflict encounters. The pattern of the conflict relationship is dependent on the conditions causing the conflict, the party's perception of the incident, and their actions toward the conflict. The parties involved in the conflict may perceive the conflict episodes differently depending on their interpretation of the incident (Dewulf, et al., 2009; Kaufman, Elliot, \& Shmueli, 2003). Pondy identified five stages of conflict as: Latent conflict (conditions), perceived conflict (cognition), felt conflict (affect), manifest conflict (behavior) and conflict aftermath (conditions). He stated that not every conflict episode passes through every stage. Robbins (1996) revised the stages to: Potential opposition or incompatibility, cognition and personalization, intentions, behavior, and outcomes.

Latent conflict refers to existing conditions in an organization or institution that create opportunities for conflict to arise; they indicate the potential for opposition or incompatibility (Robbins, 1996). The sources of this conflict could be: Competition for scarce resources, drives for autonomy, divergence of sub-unit goals (Pondy, 1967), communication break-down, and personality differences (Robbins, 1996). Competition for scarce resources can be a source of conflict if demands for resources by the participants exceed the resources available in the organization. Drive for autonomy can also be a source of conflict if any of the parties seek to exercise control over the other against their will. Finally divergence of goals can result to conflict if parties are unable to reach a consensus because of incompatible goals. This stage can only lead to conflict if either or all of the parties are affected or are aware of the existent of the dispute. 
The cognition and personalization stage contains the perceived and felt phases of conflict. Perceived conflict occur when the parties are aware of the existence of a conflict condition but are not affected by it; on contrary, felt conflict occur when the awareness of a conflict condition causes tension, anxiety, frustration, or hostility and the parties' in dispute are emotionally involved in the conflict process (Robbins, 1996). Different parties' can discern similar conflict conditions differently depending on their personality (Pondy 1967). For instance, a study by Baron (1989) found that parties with type-A personality had higher chances of encountering conflict with subordinates than parties with type-B personalities. The ability to handle anxiety during conflict also determines a person's response to the conflict situation. This stage is crucial because it determines how conflicts are defined and the succeeding actions in the conflict process. The definition of conflict at this stage determines the intentions or behaviors of the parties and delineates the possible outcomes to be reached (Robbins, 1996).

Robbins (1996) included a third stage that is not discussed by Pondy to describe the actions that the party's in dispute portray to intervene between people's perceptions and emotions and their explicit behavior. He conveyed that before conflict can escalate to either functional or dysfunctional levels, both parties could display some behavior indicating their intentions to either compete, compromise, collaborate, accommodate, or avoid the conflict situation. However, he acknowledges that behavior does not always reflect a person's intention and people's intentions can change within the course of the conflict situation. The change in a person's intentions can be as a result of their re-conceptualization of the conflict or a change in the emotional reaction to the behavior; however research shows that people are predisposed in how they handle conflicts (Rahim, 1985; Robbins, 1996; Weider-Hatfield, 1988). Some 
individuals prefer certain conflict-handling intentions more than others depending on their personality and their cognitive characteristics.

The fourth stage in the conflict process is the manifest conflict which refers to the behavior displayed by disputing parties to express the presence of conflict (Pondy, 1967). It is at this stage that conflict becomes visible. It includes the "statements, actions, and reactions made by the conflicting parties" (Robbins, 1996, p. 512) it can be demonstrated through open aggression, sabotage of other's goals and plans, or a participant's apathy in achieving organizational goals (Pondy, 1967). This stage elaborates conflict as a dynamic process of interaction on a continuum of functional and dysfunctional conflicts. Functional conflicts occur in the lower ranges of conflict intensity and they could involve minor disagreement or misunderstanding between parties. As conflict intensifies to include assertive verbal attacks, threats and ultimatums, aggressive physical attacks, and efforts to sabotage and destroy the other party it consummates to dysfunctional levels (Robbins, 1996). The behavior and consequences of conflict are overlapping phases since they occur concurrently. The final stage of conflict is referred to as conflict outcome (Robbins, 1996) or conflict aftermath (Pondy, 1967).

Conflict outcome refers to the consequences of conflict: Functional or dysfunctional outcomes (Robbins, 1996). The intensity of the conflict and the party's behavior in handling it can result to a mutual agreement or an impasse with either integrative (win-win) or distributive (win-lose) outcomes (Wall \& Callister, 1995). If conflict is at moderate levels, it can result to functional outcomes by: "Improving the quality of decisions; stimulating creativity and innovation; encouraging interest and curiosity among group members; providing a medium through which problems can be aired and fostering an environment of self-evaluation and change" (p.514). On contrary very low or very high levels of conflict can result to dysfunctional 
levels which can reduce group effectiveness and cohesiveness, retard communication, and insubordinate group goals. Studies show that internal conflicts are likely to be functional in groups that have non-routine tasks more than those that perform unvaried tasks (Robbins, 1996)

Conflict management styles. According to Jones and White (1985), there are various methods of managing conflict and they can be distinguished along winners and losers: win-lose, lose-lose, and win-win outcomes. The win-lose methods are achieved by one party's dominion over the other through the use of power, authority and majority rule. Lose-lose methods occur when none of the parties attain their goals and parties aim at compromise or withdrawal strategies. On the other hand, the win-win methods occur when both parties make a conscious decision to seek a solution that benefits all. Robbins (1996) identified conflict management styles as behaviors that people display to signify their intentions to dominate, compromise, avoid, collaborate, or accommodate in the dispute.

Similar to the managerial grid, Blake and Mouton (1964) conceptualized the conflict grid for handling interpersonal conflicts and developed five distinct conflict management styles along two axes: Concern for people and concern for production. They classified the styles as: Forcing (competing), withdrawing (avoiding), smoothing (accommodating), compromising, and problem solving (collaborating). Analogous to the team management leadership style, Blake and Mouton advocated for problem solving (collaborative) style and asserted that it was one "best way" to handle conflict. Hence, the goal of the conflict grid was to enable managers avoid the win-lose situations and possibly employ the win-win strategy-collaborating style- when handling conflicts. Burke (1970) reclassified the same styles to; withdrawing, smoothing, compromising, forcing, and confronting. Thomas (1976) redefined the two dimensions to "assertiveness" versus "cooperativeness" and developed the Thomas-Kilmann Conflict Management of 
Differences (MODE) instrument to measure the five modes of conflict resolution: Competing, accommodating, avoiding, collaborating, and compromising.

The MODE instrument differed from Blake and Mouton's conflict grid because it assumed that conflict behavior is influenced by a person's personality and situational factors (Womack, 1988). It was however reproved for weak psychometric properties which led to the development of ROCI-II instrument which measured the five styles of handling conflict with superiors, subordinates, and peers (Ben-Yoav \& Banai, 1992; Rahim, 1983, 1985). Rahim Organizational Conflict Inventory-II (ROCI-II) was designed to measure conflict management strategies along the dimensions of "concern for people" and "concern for others" (Rahim 1985). He developed the ROCI-II instrument for measuring interpersonal conflicts in three forms. Form A is in reference to conflict with superiors; Form B in reference to conflicts with subordinates, and Form $\mathrm{C}$ addresses conflicts with peers. For the purpose of this study, form B of the ROCI-II instrument was used to identify the dean's conflict management style with their subordinates. The amount of conflict at each level determines how close an organization is to functional conflict which is necessary for organizational effectiveness (Rahim, 1985; Weider-Hatfield, 1988). Rahim redefined the five conflict management strategies to: Integrating, obliging, dominating, avoiding, and compromising. Contrary to Blake and Mouton's conflict grid theory, Rahim argues that every conflict management strategy is effective depending on the situation: there is no one-best-style of conflict management. He further advocates for conflict management rather than conflict resolution on the grounds that moderate levels of conflict can result to optimal organizational effectiveness (Rahim 1985). The conflict management styles are defined as follows: 
Integrating. This method reflects a high concern for self and others. Both contenders aim at reaching an effective solution through the exchange of accurate information, openness and desire to examine each other's differences and it leads to win-win outcomes. This style is most appropriate when issues are complex and is most useful in dealing with strategic issues relating to objectives, policies and long range planning. This method is also referred to as collaborating (Thomas, 1976); problem solving (Blake \& Mouton, 1964) and confronting (Burke, 1970) style.

Obliging. This method reflects a low concern for self and high concern for others. The obliging person disregards his or her own interests and aims to satisfy the opponent's concerns. This is achieved through accentuating the commonalities in the dispute and disregarding the differences. This style is most useful when the accommodative disputants believe that they are wrong; or when they perceive the issue to be more important to the opponent. This style is most dominant in subordinate-superior conflicts and the obliging method is also referred to as accommodating (Thomas, 1976) or smoothing (Blake \& Mouton, 1964; Burke, 1970) conflict management style.

Dominating. This method reflects high concern for self and low concern for others. It can be identified with a win-lose orientation. The dominating opponents address their particular concerns at the expense of the needs and expectations of the other disputant. This style is most appropriate when the issue involved in the conflict is trivial and prompt decision is required and is suitable when unpopular courses of action must be implemented. Dominating style is also referred to as forcing (Blake \& Mouton, 1964; Burke, 1970) or competing (Thomas, 1976) conflict management style.

Avoiding. This method reflects a low concern for self and others. It can be identified with lose-lose orientation in which none of the contender's concerns are attended to. The style is 
associated with withdrawal, buck-passing or side-stepping the situation. It is most appropriate when the issues causing conflict are trivial and when the consequence of confronting the other party outweighs the benefit of resolving the conflict. This method is also referred to as the withdrawing (Blake \& Mouton, 1964; Burke, 1970) conflict management style.

Compromising. This method reflects the intermediate concern for self and others. Both parties in dispute give up their interest to achieve a mutually acceptable decision. It is most appropriate when the goals of the conflicting parties are mutually exclusive and when the contenders' concerns are of equal importance. Rahim warns that overreliance to this style may yield dysfunctional outcomes (Rahim, 1983).

Although various studies show the confronting (integrating or collaborative) style to be the most effective conflict management style and forcing or dominating styles to be the most ineffective conflict management style (Burke, 1970; Cetin \& Hacifazliogo, 2004; Cornille, Pestle, \& Vanwy 1999; Garnier, 1981; Jones \& White, 1985; Lawrence \& Lorsch,1967); Munduate, Ganaza, Peiro, \& Euwema (1999) found that the effectiveness of a conflict handling method was as a result of a combination of different styles of conflict rather than the absence or presence of particular styles. The combinations of integrating, dominating, and compromising styles were found to be most effective more than the sole use of any of the styles separately. Rahim (1985) supports this assertion by elaborating that conflict management styles are contingent to situations. Although integrating and compromising styles are deemed to be more appropriate for strategic issues; avoiding, obliging and dominating styles could be most suitable for dealing with tactical problems.

Conflict management perspectives. Conflict management has traditionally been studied from two main perspectives: The structural-functionalist perspective and the human relations 
perspective. The structural-functionalist perspective characterizes conflict as a dysfunctional phenomenon that should be prevented, eliminated, or suppressed. The advocates of this perspective advance that conflicts can be eliminated through clear specifications of employee roles, use of impersonal rules, and the emphasis on procedure to ensure organizational effectiveness. On the same thought, the human relations theorist view conflicts to be detrimental to organizational effectiveness and argue that conflicts can be resolved through employee empowerment and participation (Dee, Henkin, \& Holman, 2004; Pondy, 1967). Both perspectives view the organization as a closed system with an aim to resolve conflicts democratically through internal governance processes or through established lines of authority.

These traditional approaches to conflict management are challenged because they ignore the role of external agents such as accrediting bodies, state coordinating boards, donors, and alumni in initiating or resolving conflicts within the institution (Dee, et al., 2004; Robbins, 1996). Moreover, the conventional approach advocates for conflict suppression which could inhibit efforts to innovate and respond to emerging problems. Leaders who suppress disagreements could encounter significant opposition in professional organizations such as colleges and universities where professionals are involved in extensive organizational decisionmaking (Dee, et al., 2004). To counter these shortcomings, Dee and colleagues recognized two contemporary approaches to conflict management: Conflict regulations perspective and the paradox and contradictions perspective. The conflict regulations perspective perceives conflict to be inevitable and essential in serving organizational needs. This orientation views conflict from an "open systems" approach with the external environment both initiating and exerting pressure on organizational innovations. The role of the leader in this system is to enable change through managing conflict rather than reducing it. 
The paradox and contradictions orientation to organizational conflict perceives organizations to contain a scope of contradictions. Organizations are often faced with two opposing engagements such as the need for change or stability; integration or decentralization; or accountability and autonomy. Institutions of higher learning encounter the accountabilityautonomy paradox because of the different hierarchies that exists in higher education.

Institutions are expected to be accountable to external constituents whilst preserving institutional and faculty autonomy (Dee, et al., 2004).

Conflict in higher education. Most conflict in higher education institutions result from the tension between accountability and autonomy principles (Dee, et al., 2004). This tension is created by faculty's loyalty to professional authority and their need for autonomy and the university's need to bureaucratize its functions with an interest to ensure efficiency and accountability (Leslie, 1972; Olsen, 1986). It is demonstrated through conflicts between coordinating boards and individual campuses, boards of trustees and presidents, and academic administrators and faculty (Dee, et al., 2004). There are four conceptual models that have been developed to understand conflict management in higher education institutions: Bureaucratic, collegial, political, and anarchical models (Baldridge, 1971; Cohen \& March, 1986).

Bureaucratic model is designed to deal with superior-subordinate conflicts (Pondy, 1967) and it originates from the work of Max Weber. The model is based on the principle of legal rationality and is illustrated in institutions of higher education by the presence of formal channels of communication; hierarchy; formal policies and rules; and the emphasis of authority and legitimate power (Baldridge, 1971). It examines the role conflict faced by the middle managers as they attempt to handle demands from the superiors and subordinates (Pondy, 1967). The model perceives conflict to be problematic (Baldridge, 1971; Pondy, 1967) and aims at 
minimizing it through bureaucratic sanctions, setting up grievances systems, altering structure, setting up an ombudsmen office, and developing rules and procedures (Baldridge, 1971; Brown, 1983; Morrill, 1991; Pondy, 1967; Stanley \& Algert, 2007; Thomas, 1988; Wall \& Callister, 1995). In this model deans take an authoritative role and exercise their organizational power through legitimate means (McCarty \& Reyes, 1987).

Collegial model assumes that a university is a community of scholars with professional lines of authority. The model accentuates on technical competence rather than official competence and the ability of the professional to make decisions and participate in organizational decision-making. Similar to the human relations view, this model perceives conflict to be dysfunctional and abnormal and aims at minimizing it through consensus building (Baldridge, 1971; Stanley \& Algert, 2007). According to this model, the dean is recognized as "first among equals" in the academy (McCarty \& Reyes, 1987).

The political model assumes that the university is made up of coalitions of diverse individual and interest groups. It recognizes conflict as inevitable in institutions because of the differences among coalition members and the scarcity of resources in the organization (Bolman \& Deal, 2003; Stanley \& Algert, 2007). This model is evidenced in higher education institutions because of the presence of different interest groups and stakeholders (Baldridge, 1971). Conflict is perceived to be typical and beneficial to the organization and it is handled through bargains and negotiations (Bolman \& Deal, 2003). The dean takes the role of conflict mediator and arbitrates conflicts between various constituents (McCarty \& Reyes, 1987).

The anarchical model was developed by Cohen and March (1986) and it recognizes the university as a diverse institution with ambiguous, inconsistent and multiple goals and objectives; unclear technology; fluid participation and weak information base. The anarchical 
model can be likened to the symbolic frame of Bolman and Deal which recognizes organizations to be ambiguous with members aiming at finding meaning to situations (Bolman and Deal, 2003). Conflicts are inherent in this model because of the ambiguity and inconsistence of the goals. The dean's role is to generate useful solutions to ill-defined problems and issues (McCarty \& Reyes, 1987).

Studies have been done to identify the conflict management strategies in the academy. Conflict exists in superior-subordinate relationships among academicians (Burke, 1970); academic administrators (Cetin \& Hacifazliogu, 2004); college presidents (Dee et al., 2004); department chairs persons (Stanley \& Algert, 2007); academic deans (Donovan, 1993; Garnier, 1981; Olsen, 1986; Woodtli, 1987); and higher education adult students (Landa-Gonzales, 2008; Satterlee, 2002) among others. A study done by Burke (1970) found that functional conflict was positively correlated to confrontational conflict management strategy and negatively correlated to forcing behaviors. There was a positive correlation between superior -subordinate relationships with the confrontational (integrating) conflict management style and a negative correlation with withdrawing (avoiding), smoothing (obliging), and forcing (dominating) conflict management styles. There was however, no correlation between superior-subordinate relationships with the compromising conflict management. This finding is supported by Dee, et al., (2004) on their study on conflict management strategies of college presidents which found that college presidents were most likely to use collaborative (integrating) conflict managing methods when dealing with faculty and trustee conflicts.

In analyzing conflict management strategies among deans; Garnier (1981) found that although the most effective methods of handling conflict as perceived by associate deans was problem-solving (integrating) however, they frequently used the compromising conflict 
management style. Woodtli (1987) made the same observation among nursing deans: deans frequently use the compromising conflict handling method followed by collaborating and rarely used the competing style. On contrary, a study by Donovan (1993) found that academic deans' conflict management style was perceived by both the deans and their subordinates to be integrating, followed by compromising; avoiding style was perceived to be the least used method among academic deans.

Since research has shown conflict management to be a significant predictor of task effectiveness (Burke, 1970; Garnier, 1981; Jones \& White, 1985; Lawrence \& Lorsch, 1967) various studies have been done to identify the variables that influences a person's conflict management style. Jones and White (1985) evaluated the relationship between conflict resolution style and personality as a predictor of task effectiveness. From their study, the need for affiliation was positively related to smoothing (obliging) conflict resolution strategy and negatively related to forcing (dominating) and confrontation (integrating) conflict resolution styles. The need for deference was positive correlated to forcing (dominating) conflict resolution methods and the Machiavelli personality type was negatively correlated to smoothing (obliging) and positively related to confrontational (integrating) and forcing (dominating) styles. The study found the confrontational (integrating) method of conflict resolution to be more effective than the smoothing and forcing methods.

Jordan and Troth (2002) evaluated the relationship between emotional intelligence and preferred style of conflict resolution. The study found that individuals with high emotional intelligence preferred the collaborative (integrative) conflict resolution technique; whereas individuals with low emotional intelligence were likely to use forcing (dominating) and avoiding conflict management strategies. A study done on referent roles of Korean government 
employees and their conflict resolution style found the dominating conflict management style to be most frequently used when dealing with subordinates than when dealing with peers or superiors; the compromising conflict management style was used more often with peers than with subordinates of superiors and the obliging and avoiding styles were frequently used when dealing with superiors than with subordinates or peers (Chang-Won, 2002).

A study done by Hoffman, (2007) evaluated student leaders' sense of humor as a moderator of the relationship between their leadership style- transformation and transaction- and conflict management styles. The study found that sense of humor had a positive significant relationship with integrating and dominating styles of conflict management. The preference for avoiding conflict management style was inversely related to sense of humor and transformational leadership. As the leaders' sense of humor and transformational leadership behavior increased, their preference for avoiding conflict management style decreased. This finding is informative because a study done by Landa-Gonzales (2008) found that occupational therapy students preferred the avoiding conflict management style more than the competing or collaborative styles.

Hendel, et al., (2005) evaluated the relationship between the transformational and transactional leadership styles among head nurses with their conflict resolution style. The study found that most head nurses perceived themselves to be transformational rather than transactional leaders; however, choice of a leadership style explained only $20 \%$ of the variance in the preference of a conflict management style. Transformational leadership style was found to have a significant relationship with the competing style whereas the transactional leadership style was significantly related to collaborating and accommodating conflict management styles. Corresponding to previous studies that have shown the transformational and transactional 
leadership styles to be marginally correlated to conflict management; this study aimed to find if similar findings would be found between Bolman and Deal's leadership frames and the choice of conflict management style among academic deans.

\section{The Academic Dean}

Until the last quarter of the nineteenth century higher education colleges were relatively small and the president handled all administrative affairs of the college (Dibden, 1968; Gould, 1964; Rudolph, 1962). However, as the role of education broadened to serve the needs of the larger society and with the emergence of German university ideals, the old president was succeeded by new academic reformers who had different roles and duties. The changes in American higher education during this earlier eras resulted to greater responsibilities that required various administrative offices to be created (Lucas, 1996; McGrath, 1938). The earliest offices to be created after the office of the president were the librarian, the registrar and the dean's offices respectively (McGrath, 1938). The first college dean was appointed by president Elliot of Harvard University in 1869 (McGinnis, 1933) by 1885, there were 15 deans and over 300 deans by the year 1933 (Ward, 1934). Various reasons prompted the creation of the dean's office. In some institutions it was created to aid the duties of the president; in others it was created to assume the roles of the president incase of emergencies such as illness, resignation or death; other times it was established during the opening of a new college or as a result of college reorganization (Dibden,1968; Gould, 1964).

In 1870, the dean of Harvard was appointed to preside over faculty meetings in the absence of the president; to administer discipline to the college; to take charge of the undergraduate and faculty petitions; to keep records of admission, conduct and attendance; and to aid faculty scholarships. The role of the dean in the 1960's was narrowed to directing 
educational activities, evaluating budgets and aiding faculty scholarships as other administrative offices were created (Dibden, 1968). In the 1980's his role evolved from that of an intellectual leader to an administrative officer devoting most of his time to managerial duties, public relations activities, and administrative tasks (Dibden,1968; Montez, M. Wolverton, \& Gmelch, 2002). Turker and Bryan (1991) identified three metaphors to describe the role of the dean: Dove of peace, dragon and diplomat. The dean assumes the role of "dove of peace" by intervening in conflicts among the different interest groups. He takes the roles of a "dragon" by protecting the college from internal and external threats. Finally, he assumes the role of a "diplomat" by providing leadership to his constituents. The role of the dean is therefore that of a middle manager with a responsibility to balance expectations of different constituents.

Unlike the previous century, the $21^{\text {st }}$ century has emerged with external demands and stressors that were non-existent in the previous era resulting to advancement in dean's roles (M. Wolverton \& Gmelch, 2002). Institutions are no longer homogeneous; hence, deans have a role to represent and recruit diverse faculty and students. Changes in technological advances have altered the delivery of the curriculum. Moreover, institutions have ceased to be state-supported resulting to deans taking a fundraising role. The former role of the dean as a student counselor, teacher, and scholar has been augmented to include extra mural funding, personnel decisionmaking and external public relations (Gould, 1964; Heck, Johnsrud, \& Rosser, 2000). The dean is accountable to a greater number and more diverse constituents than his predecessor (Fagin, 1997) and his role as a scholarly leader has been replaced by an executive officer who is both politically-shrewd and economically-skilled (Gmelch, M. Wolverton, \& M.L. Wolverton, Sarros, 1999). 
As the dean's roles have evolved over time, scholars have concluded that the role and functions of the office of the dean are not standardized (Dibden, 1968; Gould 1964; Martin, 1993; McGinnis, 1933; Ward, 1934) they vary by institutional size, sponsorship, location, mission and goals of the institution (Martin, 1993; McGinnis, 1933;). Deans also vary by type: Graduate deans, academic deans, deans of students and deans of admission or by hierarchy: associate deans and assistant deans (Martin, 1993). The current study evaluated academic deans in Masters College and Universities public institutions. These institutions are classified as those colleges that award at least 200 master's degrees and 20 doctoral degrees per year (Carnegie Classification, 2010). Unlike the bachelor's degree, a master's degree is a graduate academic degree that is granted to individuals who demonstrate a mastery of higher-order skills in their professional areas as demonstrated by Bloom's taxonomy. Students attending the colleges may be non-traditional, attending college part time, working full time, and may have family responsibility which could pose a challenge to both the faculty members teaching them and the academic deans governing the colleges.

Studies on academic deans include: Roles and responsibilities (Corson, 1960; Dupont, 1956; Gould, 1964); role conflict and ambiguity (M. Wolverton, M.L. Wolverton, \& Gmelch, 1999); role in governance and decision making (Baldridge, 1971; McCarty \& Reyes, 1987) and their position in conflict management (Feltner \& Goodsell 1972) among others. Although various studies have been done to evaluate the roles and duties of the dean and their position in various aspects of governance such as institutional leadership, decision making, and conflict management; no study has attempted to evaluate the impact of a dean's leadership frame on their choice of a conflict management style. Evaluating an academic dean's inclinations in managing interpersonal conflicts is a significant predictor of administrative effectiveness; because as 
confirmed by Garnier (1981) the choice of a conflict management style is a good predictor of a dean's perceived managerial effectiveness.

Past studies reveal that academic deans follow either the structural or human relations doctrines when handling conflicts (Feltner and Goodsell, 1972). Both theories view conflict to be negative and infer that if people feel regarded by the organization they will conform to the administration. According to these doctrines, people who questioned the existing policies and practices were referred to as "trouble makers" whose talents went untapped whereas; those who worked within the system were described as "good workers" but not necessarily "productive workers" (p. 693). Studies illustrated that, deans who worked for strong autocratic presidents settled conflicts by their mandate. On the other hand, those who followed the human relations approach ignored the conflict, settled it by compromise, or resolved it through bureaucratic measures such as policy manuals or through hierarchical levels. These two approaches to managing conflict are deemed insufficient because they do not acknowledge the positive effects of functional conflicts such as stimulating creativity and challenging old ideas; increasing group efficiency and productivity; improving decision making; and promoting personal development through self awareness (Cosier \& Dalton, 1990; Derr, 1978; Robbins, 1996; Wall \& Callister, 1995). Besides this, evaluating the academic dean's role in conflict management from the structural and human relations perspectives only is inadequate because the dean's role has overtones that are more political and social than hierarchical and technical (Rosser, et al., 2003); hence there is need to evaluate dean's conflict management from a more comprehensive, multiframe perspective.

Considering higher education institutions exist within the four models of governance: bureaucratic, professional, political, and anarchical (Baldridge, 1971; Cohen \& March, 1986); 
deans' role as middle managers not only does it expose them to role conflicts and incompatible expectations from their constituents, but also it places them in a position to deal with both interpersonal and organizational conflicts in the institution. Deans face interpersonal and organizational conflicts because of scarce resources, communication barriers, time pressures, personality clashes, unrealistic standards, and impractical expectations (Kreitner, 1980). When faced with interpersonal or organizational conflicts, the proactive deans can assume the roles of an initiator, defendant, or conciliator (Feltner \& Goodsell, 1972). Since deans must balance the expectation of different constituents, their leadership effectiveness depends on their capacity to handle external pressures of accountability and internal pressures of autonomy (Dee, et al., 2004).

Deans assume the role of conflict initiators when they take up the responsibility to introduce change in the institution. Effective deans are transformational leaders with a role to change the institution's culture and disrupt the status quo (M. Wolverton \& Gmelch, 2002). Deans may initiate change in areas such as curriculum revision, instructional innovation, administrative policies, and personnel concerns. Efforts to bring about such changes may be met with some resistance which could be a significant source of conflict in the institution (Feltner \& Goodsell, 1972). In spite of this, the dean's role as a change and conflict initiator can yield effective leadership because a leader's ability to ensure a moderate level of conflict through initiating change is decisive in determining optimum organizational effectiveness (Rahim, 1985).

Deans position as middle level managers can propel them to take the role of a defendant in a conflict situation incase their decisions are disputed by the members of the academy. Their functions as academic leaders and as administrative officers make them accountable for emotional and sensitive decisions such as; faculty promotions, tenure, and salary; budget 
allocations; and curriculum reforms (Feltner \& Goodsell, 1972) which could spur conflict. According to Woodtli (1987) the three most destructive sources of conflicts among nursing deans were interpersonal and they identified them as: faculty workload, personality differences, and relationship with peers.

Deans can also assume the role of a conflict conciliator when they mediate between faculty-student conflicts; faculty-administration conflicts; conflicts within and between departments, colleges and other institutions. According to Rosser et al. (2003), deans serve as academic facilitators between presidential initiatives, faculty governance, and student needs. By virtue of their midlevel placements within the higher education structures; they are in the center of controversy, conflict and debate and have a role to play as coalition builders, negotiators, and facilitators.

According to Donovan (1993), an academic dean's conflict management style may depend on the organizational culture of their institutions if bureaucratic or collegial; the power relations as relates to their leadership position in the hierarchy; and their personal preference for particular conflict styles. Although deans are at the center of controversy and conflict in the institution; no research has been done to identify if there is a relationship between an academic dean's leadership orientation and conflict management style. Moreover, no research has explored the role of leadership on conflict management using the Bolman and Deal's leadership orientation theory and the Rahim Organizational Conflict Inventory -II (ROCI-II) conflict management instrument. 


\section{Summary of the Literature Review}

This chapter has reviewed literature on: Leadership theories, Conflict management styles and the Academic dean. Six main leadership theories (trait, behavioral, contingency, power and influence, cognitive theory and cultural and symbolic theories) of leadership are outlined. More specifically, the Bolman and Deal cognitive theory is broadly reviewed. The literature also reviews studies on higher education administrator's leadership frames and styles.

The literature offers a review of conflict management styles and perspectives; stages and sources of conflict; and conflict management in higher education. It analyses the five conflict management styles identified by Rahim: Integrating, dominating, compromising, avoiding, and obliging styles and identifies the dominant conflict management styles adopted by various administrators in higher education.

Finally, the literature reviews the role of academic dean in the academy and more specifically their role in conflict management. According to existing literature, deans handle conflict from a structural and human resource approach which is oblivious of the political and symbolic leadership theories in handling conflict among academic deans. The current research evaluated conflict management styles of academic deans from an inclusive perspective which includes all the four frames of leadership. Moreover it compared the Bolman and Deal's fourframe leadership theory with Rahim Organizational Conflict Inventory-II conflict management instrument in understanding the leadership role of academic deans in conflict management. 


\section{Chapter III}

\section{Research Method}

This chapter will discuss five main sections: Research design, participants in the study, instrumentation, collection of data, and data analysis. The study provided research regarding academic deans' leadership orientation and conflict management styles. It utilized two instruments: Bolman and Deal's Leadership Orientation Inventory -Self version (LOI- Self) (see appendix F, section B for the instrument) and Rahim Organization Conflict Inventory- II (ROCIII) Form B Instrument - used with permission from the Center for Advanced Studies in Management- (see appendix F, section $\mathrm{C}$ for the instrument). A demographic section preceded the instruments (see appendix F, section A for the questions).

\section{Design of the Study}

The study involved a quantitative research design and it provided both descriptive and inferential analysis to determine if there was a relationship between academic deans' leadership frames, styles, and conflict management styles. Data was gathered through structured questionnaires. Both instruments were administered to academic deans who evaluated their leadership orientation as measured by the Leadership Orientation Instrument (LOI-Self) and conflict management styles as measured by Rahim Organizational Conflict Inventory- II (ROCIII) Form B instrument. A demographic section preceded the two instruments to identify the academic discipline, experience, faculty size, and gender of the participants.

\section{Participants of the Study}

The population of the study were academic deans in the colleges of Business and Education at public Masters College and Universities-Larger programs in the United States $\mathrm{N}=287$ ( Carnegie Classification, 2010). These two colleges were considered for the study 
because majority of the colleges in the Masters Degree institutions offer them: Out of the 166 Master's Colleges and Universities; 145 colleges offer degrees in Education and 142 colleges offer degrees in Business (Carnegie Classification, 2010). The two colleges are distinct from each other; their offerings do not overlap.

The college names of Business and Education vary by institution; however, for the purpose of simplicity, those that were considered had the subject either business or education as the main fields. Hence, the colleges of Business included: College or School of Business; Business Administration; Business and Economics; Business and Public Administration; Business Administration and Public Policy; Business and Computer Science; Business and Management; Business and Applied Science; Business and Technology; Business and Leadership; Commerce and Business Administration; and Business, Information, and Social Science. The colleges of Education included: College or School of Education; Teacher Education and Leadership; Education and Allied Studies; Education and Integrative Studies; Education and Human Development; Education and Human Services; Education and Professional Studies; Education and Teaching; Education and Psychology; Education and Technology; Education and Behavioral Sciences; and Education, Public Policy, and Civic Engagement.

A census was done on 287 academic deans heading the colleges of Business and Education (see Table 1). The list of the deans and their contact information was obtained from the Higher Education Publications, Incorporated (2010). Out of the 287 academic deans, 247 academic deans were contacted by electronic mail. Ninety three academic deans responded to the survey yielding a response rate of $37.6 \%$. 
Table 1

Names of colleges and number of academic deans

\begin{aligned} \hline Colleges & Number of deans \\ \hline College of Business & 142 \\ - & College or School of Business \\ - & Business Administration \\ - & Business and Economics \\ - & Business and Public Administration \\ - & Business Administration and Public \\ & Policy \\ - & Business and Computer Science \\ - & Business and Management \\ - & Business and Applied Science \\ - & Business and Technology \\ - & Business and Leadership \\ - & Commerce and Business \\ & Administration \\ - & Business Information and Social \\ & Sciences \end{aligned}

College of Education

- College or School of Education

- Teacher Education and Leaders

- Education and Allied Studies

- Education and Integrative Studies

- Education and Human Development

- Education and Human Services

- Education and Professional Studies

- Education and Teaching

- Education and Psychology

- Education and Technology

- Education and Behavioral Sciences

- Education, Public Policy and Civic Engagement

Note: The table presents the names of all Business and Education colleges in Master's College of Universities Public institutions. Although the actual number of deans in these colleges is 287, the survey instrument was sent to 247 deans $(\mathrm{N}=247)$. 


\section{Instrumentation}

Two separate questionnaires: LOI-Self and ROCI-II Form B were used to gather data on academic dean's leadership frames and conflict management styles; both instruments were selfreported. The LOI-Self instrument included 32 five-point Likert scale questions and required respondents to indicate the degree to which each of the statements was true of them (1-never, 2Occasionally, 3- Sometimes, 4- Often, and 5- Always). It was designed to measure eight separate dimensions of leadership - two for each frame: Human resources frame included supportive and participative dimensions; structural frame: Analytic and organized dimensions; political frame: Powerful and adroit dimensions; and the symbolic frame included inspirational and charismatic dimensions (Bolman and Deal, 1991a, p.12). Responses to the 32 questions indicated the leadership frames -structural, human resource, political or symbolic- that respondents used pre-dominantly. A respondent was determined to have a no frame, single frame, pair-frame, or multi-frame leadership styles depending on the number of frames that they expressed. Categories with averages of 4.0 or above were considered the predominant leadership frames of the respondents.

The second questionnaire was the ROCI-II - Form B instrument and it was also administered to the academic deans in the colleges of Business and Education. Form B domain of the ROCI-II instrument evaluates an administrator's conflicts with the subordinates which was the scope of this study. It was developed by Rahim (1983) to measure five independent dimensions of handling interpersonal conflict- Integrating, obliging, dominating, compromising, and avoiding. It included 28 items, designed on a five-point Likert scale (1- strongly disagree and 5- strongly agree), that describe specific behaviors that people are likely to display in a conflict situation. Respondents were asked to indicate the extent to which the behaviors were a 
reflection of their own behavior during a conflict situation. The styles with the highest averages were considered the predominant conflict management styles of the respondents.

The two instruments were preceded by a demographic section that was designed by the researcher to gather information regarding the participants' age, gender, work experience, faculty size, and academic discipline. Permission to use the instruments was obtained before research was conducted (see appendices D and E for permission letters).

The LOI (Self) and ROCI-II instruments were chosen for this study because they allow the analysis of respondent's dispositions in choosing a leadership frame or conflict management style. They have also been tested for internal reliability and have been identified to have high levels of reliability. LOI (Self) instrument demonstrates high reliability with structural frame having a Cronbach alpha of 0.92; human resources frame; 0.93, political frame; 0.91 and symbolic frame; 0.93 (Bolman and Deal, 1991a; Sasnett and Ross, 2007). The validity of the LOI-instruments both self and others; has been ascertained by various researchers: Bolman and Deal (1991a) collected data from 680 senior administrators in higher education, among other studies, and found the four frames of leadership to emerge clearly after conducting factor analysis. Additionally various studies have been done on higher education administrators and have proven the validity of the instrument in measuring the leadership frames and styles of the administrators (Bensimon, 1987; Bolman \& Deal, 1991a; Cantu, 1997; Chang, 2004; Crist, 1999; Mosser \& Walls, 2002; Sasnett \& Ross, 2007).

In assessing the conflict management instruments available; ROCI-II was identified to be the most appropriate instrument because it demonstrates high internal reliability ranging from .67 to .77 (Rahim, 1983; Weider-Hatfield, 1988; Womack, 1988) and the test-retest reliability is higher than all the other instruments (Womack, 1988). According to Ben-Yoav and Banai 
(1992) ROCI-II instrument also demonstrates satisfactory evidence of factorial independence of the five conflict styles. Various studies have also ascertained the concurrent and predictive validity of the instrument (Ben-Yoav \& Banai, 1992; Rahim, 1983; Weider-Hatfield, 1988; Womack, 1988). Unlike other conflict management instruments like Hall's CMS (1969) and Putnam and Wilson's OCCI (1982); the ROCI-II instrument indicates low social desirability (Ben-Yoav \& Banai, 1992; Womack, 1988). Moreover, on analyzing the effect of self and peer ratings across ROCI-II and Thomas-Kilmann MODE instruments, Ben-Yoav and Banai (1992) found that although both instruments had comparable reliability estimates, the alpha coefficients of the ROCI-II instrument on self-ratings were closer to .80 than the alpha coefficients of the MODE instrument. This analysis made the ROCI-II instruments the most appropriate instrument to measure the dean's self-perceived conflict management style. These two instruments were also considered to be the most appropriate constructs for this study because they both acknowledge the influence of individual cognition abilities and dispositions on the choice of conflict management styles (Bolman \& Deal, 1991a; Weider-Hatfield, 1988).

\section{Data Collection}

The researcher created a mailing list of all academic deans heading Business and Education schools in Master's Colleges and Universities Public institutions. The academic dean's contact information was obtained from the Higher Education Directory (Higher Education Publication, Inc, 2010) and it includes the participants' institution, type of college, email address, and phone number. Participants were sent an electronic version of LOI-Self and ROCI-II Form B instruments, through the use of survey monkey software, with permission from the instruments developers. An email requesting acceptance to participate in the study was also sent and it 
outlined the purpose of the study and its objectives and also assured participants of data anonymity (see Appendix B for dean's cover letter).

Participants were encouraged to respond within two weeks; however, those who failed to respond within a month's time were reminded through an automatic response function of survey monkey software. Considering that data collection occurred during the months of summer, when most deans were away for vacation, the researcher found the need to send three separate follow-up emails over the four months of summer to increase the response rate. (See Appendix C for dean's reminders). Data collection ceased after four months from the initial start date of the study. Participant anonymity was ensured through the use of identity protection settings within the survey monkey software and their identity associated only with the completion or non-completion of the instrument. The study was approved by West Virginia University's Institutional Review Board for the protection of Human subjects (see Appendix A for IRB review).

\section{Data Analysis}

The responses obtained on the survey monkey software were inserted in an SPSS (statistical package for the social sciences) data file. The researcher decided to explore the data to check if it met the assumptions of normality and homogeneity of variance and hence determine the most appropriate inferential statistics to be used. From the results, not only was the data ordinal but also it did not meet the assumptions of parametric data. Hence, most of the supposed statistical analyses were changed from parametric analysis to non-parametric analysis. According to Field (2005), non-parametric tests are also known as assumption-free tests because they make fewer assumptions about the type of analysis to be used for certain data-sets. Field asserts that for data that does not meet the assumptions of parametric tests, the non-parametric 
tests are the most "appropriate in achieving accurate results" (p. 521). Descriptive statistics such as frequencies and standard deviations were used to describe the demographic variables; whereas the inferential statistics were used to analyze the differences and relationships between the variables.

The following research question determined the statistical methods to be performed:

RQ1. What leadership frames, styles, and conflict management styles do academic deans in Business and Education colleges in Public Masters College and Universities' Carnegie Classification demonstrates? Descriptive statistics were used to analyze the first research question. Frequencies, averages, and dispersions obtained determined the academic deans' use of the four frames of leadership (structural, human resource, political and symbolic); leadership styles (no frame, single frame, pair-frame, and multi-frame) and conflict management styles (integrating, obliging, compromising, dominating, and avoiding) as perceived by the academic deans.

RQ2. Are there significant differences between deans' leadership frames, styles, and conflict management styles in the context of type of college, gender, age, experience as a dean and in academia, or faculty size? The responses of the deans were grouped by type of college (Business or Education); gender (male or female); age (40 years and below, 41-50 years, 51-60 years, over 60 years); faculty size (Small: Less than 20 members of faculty; Medium: More than 20, but less than 40 members of faculty; Large: More than 40 members of faculty in the college); number of years in the position of an academic dean (short-term: less than 3 years; medium: 3 to 5 years and long-term: more than 5 years); and number of years in academia (less than five years; between five and ten years; more than ten years). Considering some of the categories yielded very small sample sizes such as faculty size, number of years in the position, 
and number of years in academia; some of their groupings were clustered together to facilitate the data analysis. Frequencies and percentages of deans demonstrating the structural, human resource, political, and symbolic frames and their combinations into single frames, paired frames, or multi-frame styles were identified. Deans with no espoused leadership frames were considered to have a no frame leadership style. Frequencies were also determined for the integrating, dominating, avoiding, obliging, and compromising conflict management styles.

Chi-Square test for independence was used to test if there were significant associations between academic deans' leadership frames, and styles in relation to gender, number of years in the position, number of years in academia, faculty size, and type of college. For data that did not yield at least five observations for each cell, an assumption for the Chi-Square analysis, the Phi coefficient of association, an alternative symmetric measure of Chi-Square, was used because it did not require the assumption of five observations for each cell. To further supplement the Chisquare analysis, an odds ratio was calculated for each significant finding to measure the effect size of the association. To test for significant differences in conflict management styles with the six demographic variables, Mann-Whitney U test, an alternative test to the t-test, was the most appropriate to analyze differences in ordinal data.

RQ3. Are there significant relationships between deans' leadership frames, styles, and conflict management styles? Spearman Rho tests, an alternative test to the Pearson R correlation, was performed to evaluate significant relationships between deans' leadership frames, styles, and conflict management styles. The Spearman Rho analysis was determined to be the most appropriate statistical tool to analyze ordinal data that did not meet the assumptions of parametric test. The next chapter presents the results of data analysis 


\section{Chapter IV}

\section{Results and Data Analysis}

This chapter presents the analysis of leadership frames, styles, and conflict management styles of Business and Education deans heading Public Masters Colleges and Universities- Large programs (Carnegie Classifications, 2010). More specifically, it will analyze the following research questions: RQ1. What leadership frames, styles and conflict management styles do Academic deans in Public Masters Colleges and Universities demonstrate? RQ2. Are there significant differences between Academic deans' leadership frames, styles, and conflict management styles in the context of gender, experience, faculty size, or type of college? RQ3. Are there significant relationships between deans' leadership frames, styles, and conflict management styles?

Two main instruments were used in this study: Bolman and Deal Leadership Orientation Inventory (LOI- self) (see Appendix F, section B for instrument) and Rahim Organization Conflict Inventory (ROCI-II) form B; (see Appendix F, section C for instrument). The LOI-Self instrument was used to measure academic deans' leadership frames and styles; whereas the ROCI-II form B instrument was used to assess academic dean's conflict management styles with their subordinates. Both instruments were self-report questionnaires and were preceded by a demographic section that asked question on academic deans' gender, age, type of college, faculty size, number of years as a dean, and number of years in academia (see Appendix F, section A for questions).

Bolman and Deal (2003) developed a four-frame leadership model that evaluated the lenses through which leaders make sense of their organizations. They identified the frames as structural, human resources, political, and symbolic. The combination of one or more leadership 
frames results to three pre-dominant leadership styles: Single-frame, pair-frame and multi-frame styles. Leaders with no dominant leadership frame are identified to have a no-frame leadership style. On the other hand, ROCI-II form B instrument measured five conflict management styles: Integrating, dominating, compromising, dominating and avoiding. Styles with the highest averages were considered predominant conflict management styles.

\section{Survey Responses and Demographic Information}

The population of the study included 287 academic deans heading the colleges of Business and Education in masters' institutions. Out of the 287 academic deans, 14 positions were identified as vacant by the Higher Education Publication (2010), nine in colleges of Education and five in colleges of Business. Ten of the deans did not have their contact information uploaded on the directory, 16 of the acquired email addresses were reported as undeliverable and hence, the number of deans sent the survey instrument was 247 . Out of the 247 delivered surveys, 25 deans opted out of the survey, while 93 deans responded to the survey yielding a response rate of $37.6 \%$. This response rate is considered sufficient because according to the research findings of Ketter, Kennedy, Dimock, Best, and Craighill (2006) and Visser, Krosnick, Marquette, and Curtin (1996) "surveys with low response rates are not necessarily low in validity" (p. 182). More specifically Ketter et al., (2006) found no significant difference between a rigorous survey that yielded a response rate of 50-61\% with that of a standard five-day survey that yielded a response rate of $25-36 \%$, despite the former achieving a significantly higher response rate. Data was collected over a four-month period, $3^{\text {rd }}$ June, 2010 to $29^{\text {th }}$ September, 2010. Respondents were sent an original email and three email reminders during the same period. The results on Table 2 indicate that $57 \%$ belonged to the colleges of education and $43 \%$ belonged to the colleges of business. 
Table 2:

Academic deans' demographic information

\begin{tabular}{|c|c|c|c|}
\hline \multirow[t]{2}{*}{ Demographics } & \multirow[t]{2}{*}{ Categories } & \multicolumn{2}{|c|}{ Response } \\
\hline & & $\mathbf{N}$ & $\%$ \\
\hline \multirow[t]{3}{*}{ Name of College } & Business & 40 & $43.0 \%$ \\
\hline & Education & 53 & $57.0 \%$ \\
\hline & Total & 93 & $100.0 \%$ \\
\hline \multirow[t]{3}{*}{ Gender } & Male & 69 & $74.2 \%$ \\
\hline & Female & 22 & $23.7 \%$ \\
\hline & Total & 91 & $97.8 \%$ \\
\hline \multirow[t]{4}{*}{ Age group } & $41-50$ years & 42 & $45.2 \%$ \\
\hline & $51-60$ years & 10 & $10.8 \%$ \\
\hline & Over 60 years & 39 & $41.9 \%$ \\
\hline & Total & 91 & $97.8 \%$ \\
\hline \multirow[t]{4}{*}{ Number of years as dean } & Less than three years & 24 & $25.8 \%$ \\
\hline & Three to five years & 16 & $17.2 \%$ \\
\hline & More than five years & 53 & $57.0 \%$ \\
\hline & Total & 93 & $100.0 \%$ \\
\hline \multirow[t]{3}{*}{$\begin{array}{c}\text { Number of years in } \\
\text { academia }\end{array}$} & Between five and ten years & 3 & $3.2 \%$ \\
\hline & More than ten years & 90 & $96.8 \%$ \\
\hline & Total & 93 & $100.0 \%$ \\
\hline \multirow[t]{3}{*}{ Faculty Size } & $21-40$ members & 20 & $21.5 \%$ \\
\hline & More than 40 members of faculty & 73 & $78.5 \%$ \\
\hline & Total & 93 & $100.0 \%$ \\
\hline
\end{tabular}


Male respondents were the majority with a response rate of $74.2 \%$. Most of the deans were under the age of $60(56 \%)$ had worked in the position of a dean for more than five years (57\%); and reported having worked in academia for more than ten years $(96.8 \%)$. Respondents were also requested to indicate the names of their terminal degrees (Table 3). From the openended results, various departmental themes emerged such as Business administration which included terminal degrees in Business Administration, Marketing, Organizational Studies, Organizational Communications, Organizational Training and Development, and Doctor of Business Administration (DBA). Other terminal degrees in the colleges of business included Masters in Business Administration (MBA), Economics, Accounting and Finance, Strategic Management, and Management and Management Information Systems.

Among the colleges of education, the departmental themes that emerged are education which included terminal degrees in Education, Adult Education, Elementary Education, Child and Human Development, and Demography. The other terminal degrees in the colleges of education included Curriculum and Instruction, Instruction Technology, Special Education, Physical Education, Psychology, Research Statistics, and Education Leadership Studies. Some deans indicated having a Ph.D and others an Ed.D as their terminal degrees; whereas others indicated a combination of the Ed.D degree and JD degree in law.

Majority of the deans in the colleges of business had terminal degrees in accounting and finance and business administration subject fields (8.6\%); compared to those in the colleges of education who had terminal degrees in education and educational leadership studies subject fields. Most of the deans did not indicate their terminal degrees $(58.1 \%)$ however those with a $\mathrm{PhD}$ were $18.3 \%$ whereas those with an Ed.D were 9.7\%. 
Table 3

Academic deans' terminal degrees

\begin{tabular}{|c|c|c|c|}
\hline & Terminal degrees & $\mathbf{N}$ & $\%$ \\
\hline Colleges of & Accounting and Finance & 8 & 8.6 \\
\hline \multirow[t]{4}{*}{ Business } & Business Administration & 8 & 8.6 \\
\hline & Economics & 5 & 5.4 \\
\hline & Strategic Management & 2 & 2.1 \\
\hline & $\begin{array}{l}\text { Management and Management } \\
\text { Information Systems }\end{array}$ & 4 & 4.3 \\
\hline Colleges of & Education & 14 & 15.1 \\
\hline \multirow[t]{7}{*}{ Education } & Curriculum and Instruction & 8 & 8.6 \\
\hline & Instruction Technology & 1 & 1.1 \\
\hline & Physical Education & 1 & 1.1 \\
\hline & Special Education & 5 & 5.4 \\
\hline & Education Leadership Studies & 14 & 15.1 \\
\hline & Psychology & 1 & 1.1 \\
\hline & Research & 2 & 2.1 \\
\hline \multirow[t]{6}{*}{ PhD/Ed.D } & $\mathrm{PhD}$ & 17 & 18.3 \\
\hline & Ed.D & 9 & 9.7 \\
\hline & Ed.D and J.D (Law) & 3 & 3.2 \\
\hline & DBA & 1 & 1.1 \\
\hline & MBA & 3 & 3.2 \\
\hline & Not specified & 54 & 58.1 \\
\hline
\end{tabular}

Note: This table represents the open-ended responses of academic deans' subject of their terminal degrees. It is organized by subject field and deans' specified terminal degree. 


\section{Statistical Analysis of the Data}

Two instruments, Leadership Orientation Inventory (LOI- self) and Rahim

Organizational Conflict Inventory (ROCII-II) form B, were used to evaluate the leadership frames and styles and the conflict management styles of academic deans respectively. The LOISelf included 32 five-point Likert scale questions that required the respondents to indicate the extent to which each of the statements was true of them ranging from 1 (never) to 5 (always). Categories with a mean score of 4.0 or above (often and always) were considered the predominant leadership frames of the respondents. On the other hand, ROCI-II also designed on a five-point Likert scale was used to evaluate the conflict management styles of academic deans with their subordinates. It contained 28 statements of which respondents were asked to state the extent to which they agree displaying specific behaviors during a conflict situation. Styles with the highest averages were considered predominant conflict management styles.

Descriptive statistics were used to analyze the frequencies for all the research questions. The data was explored to find out if it met the assumptions of parametric data and hence determine the appropriate inferential statistics to be used as shown in Table 4. From the results on Table 4, some elements in the three variables did not meet the assumptions of parametric test hence; non-parametric tests were used to analyze the questions. According to Field (2005), nonparametric tests are also known as assumption-free tests because they make fewer assumptions about the type of analysis to be used for certain data-sets. For data that does not meet the assumption of normality and homogeneity of variance, non-parametric tests are the most “appropriate in achieving accurate results" (p.521). 
Table 4.

Testing the Assumptions of Normality and Equality of Variance

\begin{tabular}{|c|c|c|c|c|c|c|c|}
\hline \multirow[t]{2}{*}{ Variables } & \multicolumn{3}{|c|}{ Descriptives } & \multicolumn{2}{|c|}{$\begin{array}{l}\text { Kolmogorov-Smirnov } \\
\text { Test for Normality }\end{array}$} & \multicolumn{2}{|c|}{$\begin{array}{c}\text { Levene's Test for equality of } \\
\text { variance }\end{array}$} \\
\hline & $\mathbf{N}$ & Mean & $\begin{array}{c}\text { Std. } \\
\text { Deviation }\end{array}$ & Statistic & Sig. & $\mathbf{F}$ & Sig. \\
\hline \multicolumn{8}{|c|}{ Leadership Frames } \\
\hline Structural & 89 & 4.0941 & .50540 & .093 & $.056 *$ & 1.220 & .272 \\
\hline Human Resource & 89 & 4.3042 & .47931 & .106 & .016 & .008 & .929 \\
\hline Political & 89 & 3.8204 & .49297 & .078 & $.200 *$ & .396 & .531 \\
\hline Symbolic & 89 & 3.8468 & .54953 & .093 & $.057 *$ & .295 & .589 \\
\hline \multicolumn{8}{|l|}{ Leadership Styles } \\
\hline No-Frame & 93 & .1505 & .35954 & .512 & .000 & 5.372 & $.023 *$ \\
\hline Single-Frame & 93 & .1720 & .37946 & .503 & .000 & 1.498 & .224 \\
\hline Pair-Frame & 93 & .2473 & .43379 & .468 & .000 & 1.108 & .295 \\
\hline Multi-Frame & 93 & .3871 & .48973 & .398 & .000 & 12.429 & $.001 *$ \\
\hline \multicolumn{8}{|c|}{ Conflict Management Styles } \\
\hline Integrating & 83 & 4.3343 & .47797 & .112 & .012 & .238 & .627 \\
\hline Obliging & 83 & 3.3725 & .44826 & .101 & .036 & .085 & .771 \\
\hline Dominating & 83 & 2.9265 & .71022 & .085 & $.200 *$ & 3.403 & .069 \\
\hline Avoiding & 83 & 2.9313 & .66486 & .089 & $.157 *$ & .033 & .856 \\
\hline Compromising & 83 & 3.7681 & .50724 & .170 & .000 & 4.108 & .046 \\
\hline
\end{tabular}

Note. Kolgomoriv-Smirnov test of normality confirms the assumption of normality if p-value is greater than 0.05 $\left({ }^{*} \mathrm{p}>0.05\right)$.

Levene's test for equality of variance confirms the violation of the assumption of homogeneity of variance if $p$-value is less than $0.05(* \mathrm{p}<0.05)$. 
Kilgomoriv-Smirnov test of normality confirms the assumption of normality if p-value is greater than $0.05(\mathrm{p}>0.05)$. As shown in Table 4 , the human resource frame violated the assumption of normality $\mathrm{D}(88)=0.106, \mathrm{p}<0.05$. Also, all the leadership styles data set did not meet the assumption of normality because they were categorical and not continuous. Besides that, all the conflict management styles, other than the avoiding and dominating conflict management style, had non-normal distributions: integrating $\mathrm{D}(83)=0.112, \mathrm{p}<0.05$, obliging $\mathrm{D}$ $(83)=0.101, \mathrm{p}<0.05$, and compromising $\mathrm{D}(83)=0.17, \mathrm{p}<0.05$. The data was further explored to check for the assumption of homogeneity of variance. Levene's test for equality of variance confirms the violation of the assumption of homogeneity of variance if p-value is less than 0.05 $(\mathrm{p}<0.05)$. For the above data set, all the leadership frames and conflict management styles had a non-significant Levene test meaning that the assumption of homogeneity of variance had been met. However, on exploring the leadership style of academic deans, the no-frame leadership style $F(1,91)=5.37, p<0.05$ and the multi-frame leadership style $F(1,91)=12.43, p<0.05$ had significant variations meaning that the assumption of homogeneity of variance had been violated. Considering the violation of parametric tests in all the data sets; non-parametric tests were determined to be the most appropriate for this study.

Types of analysis. This section describes the types of analysis used on the three main research questions: RQ1. What leadership frames, styles, and conflict management styles do Academic deans in Public Masters Colleges and Universities demonstrate? RQ2. Are there significant differences between deans' leadership frames, styles, and conflict management styles in the context of gender, experience, faculty size or type of college? RQ3. Are there significant relationships between deans' leadership frames, styles, and conflict management styles? 
For research question one, descriptive analyses- means and standard deviations- were computed to determine the leadership frames, styles, and conflict management styles of Academic deans in Business and Education colleges. In analyzing research question two, nonparametric tests were used to determine if there are significant differences or associations between deans' demographic information with their leadership frames, styles, and conflict management styles.

The second research question used the Chi-Square test of association to analyze if there are significant association between the leadership frames and styles with the deans' type of college, gender, age, number of years in academia, number of years as a dean, and the size of faculty. This type of analysis was chosen because the data set for the leadership frames and styles is categorical. For categories that did not meet the assumptions of Chi-Square test of association, a frequency of at least five observations in each cell, the Phi coefficient of association was used. Phi coefficient of association is an alternative symmetric measure of the Chi-Square and it is used for small sample sizes when the Chi-Square assumption is not met (Field, 2005). To further augment the Chi-Square analysis the odds ratio was calculated to measure the effect size of the various association(s). To determine if there were significant differences in the demographic variables with conflict management styles; Mann-Whitney U test was used. The Mann-Whitney $\mathrm{U}$ test is an alternative to the t-test and it is used to compare two population means that come from the same population (Field, 2005).

The distinction in the choice of the non-parametric tests in the second research question was accounted to by the differences in the computation of the leadership frames, styles, and conflict management styles. As stated earlier, the leadership frames were determined by the number of questions that the deans scored a mean score of four or five (often or always). Deans 
who scored a mean score of less than four (never, occasionally or sometimes) on the LOI instrument were considered as having a no frame leadership style. On the other hand, deans with at least one leadership frame were regarded as having a single-frame leadership style; those with two frames were paired-frame while those with three or four frames were considered as having a multi-frame leadership style. Hence, the categorical nature of the frames and styles data set makes it suitable to conduct Chi-Square analysis (Suskie, 1996).

Contrary to this, the conflict management styles were determined by the deans' average scores on all the 28 questions on the ROCI-II instrument. Unlike the data on the LOI instrument, data collected from the ROCI-II was ordinal as it was collected from questions asking the extent to which respondents agree to the various conflict statement (strongly agree, agree, neither agree nor disagree, and strongly disagree). Hence, the Mann-Whitney U test was used because it is the most appropriate analysis to determine the differences in ordinal data (Suskie, 1996). For research question three, the Spearman Rho tests, an alternative to the Pearson R correlations, was used to evaluate if there are significant relationships between deans' leadership frames, styles, and conflict management styles.

\section{Major Findings}

RQ1. What leadership frames, styles, and conflict management styles do Academic deans in Masters Colleges and Universities demonstrate? In an attempt to answer the first research question, the three main variables were analyzed. The means and standard deviations of the elements in each variable were scored and tabulated. Descriptive statistics were used to determine the usage of the four leadership frames and styles and the five conflict management styles of academic deans heading Business and Education colleges in Masters Colleges and Universities institutions. 
Leadership frames. The mean responses for all the leadership frames were high ranging from 3.82 for the political frame and 4.3 for the human resources frame as shown in Table. 5 . The standard deviations were also modest and consistent among the four frames ranging from .47 for the human resources frame and .55 for the symbolic frame. In comparing business and education deans, the educations deans scored higher mean scores in all the four frames. From the results, most deans indicated the 32 leadership orientation questions to be, often (4) or always (5), true of them with few exceptions indicating otherwise for the political and symbolic leadership frames.

Leadership styles. The means scores of the leadership frames were tabulated to determine the deans' leadership styles. The combination of, or lack of, one or more frames determined the dean's leadership style (see Table 6). Deans who scored less than 4.0 of any of the frames were considered to have a no-frame leadership style. The respondents reported using the multi-frame leadership style most frequently $(38.71 \%)$ and the no-frame least frequently $(15.05 \%)$. The paired frame came in a distant second $(24.73 \%)$ and the single frame was third $(17.20 \%)$. It is interesting to note that, almost half of the education deans had a multi-frame leadership style (47.17\%). The results of the paired and multi-frames for the business deans and those of the noframe and single frame were identical (27.5\%) and (20\%) respectively. More specifically within the multi-frame leadership style $26.9 \%$ of the deans used all the four frames of leadership (Table 7). Within the paired-frame style the structural-human resources combination was used most frequently (19.4\%); whereas, within the single-frame style, the human resource frame was the most frequently used (14\%). 
Table 5

Leadership Frames of Business and Education deans in Masters Institutions

\begin{tabular}{llcccc}
\hline Name of college & & $\begin{array}{c}\text { Structural } \\
\text { Frame }\end{array}$ & $\begin{array}{c}\text { Human } \\
\text { Resource } \\
\text { Frame }\end{array}$ & $\begin{array}{c}\text { Political } \\
\text { Frame }\end{array}$ & $\begin{array}{c}\text { Symbolic } \\
\text { Frame }\end{array}$ \\
\hline Business & Mean & 4.0197 & 4.2204 & 3.6979 & 3.6945 \\
& Std. Dev & .48240 & .49100 & .49107 & .56279 \\
Education & Mean & 4.1495 & 4.3666 & 3.9093 & 3.9573 \\
& Std. Dev & .51963 & .46544 & .47963 & .51749 \\
Total & Mean & 4.0941 & 4.3042 & 3.8204 & 3.8468 \\
& Std. Dev & .50540 & .47931 & .49297 & .54953 \\
\hline
\end{tabular}

Table 6

Leadership styles of Business and Education deans in Masters Institutions

\begin{tabular}{cccccc}
\hline Name of College & & No Frame & Single Frame & $\begin{array}{c}\text { Paired } \\
\text { Frame }\end{array}$ & Multi-Frame \\
\hline Business & $\mathrm{N}$ & 8 & 8 & 11 & 11 \\
& $\%$ & 20 & 20 & 27.50 & 27.50 \\
Education & $\mathrm{N}$ & 6 & 8 & 12 & 25 \\
& $\%$ & 11.32 & 15.09 & 22.64 & 47.17 \\
Total & $\mathrm{N}$ & 14 & 16 & 23 & 36 \\
& $\%$ & 15.05 & 17.20 & 24.73 & 38.71 \\
\hline
\end{tabular}


Table 7

Frequency distribution of styles by frames

\begin{tabular}{|c|c|c|c|}
\hline Styles & Frames & $\mathbf{N}$ & $\%$ \\
\hline No Frame & & 14 & 15.1 \\
\hline \multirow[t]{5}{*}{ Single Frame } & Structural & 2 & 2.2 \\
\hline & Human Resource & 13 & 14 \\
\hline & Political & 1 & 1.1 \\
\hline & Symbolic & 0 & 0 \\
\hline & Total & 16 & 17.2 \\
\hline \multirow[t]{7}{*}{ Paired-Frame } & Structural-Human resource & 18 & 19.4 \\
\hline & Structural-Political & 0 & 0 \\
\hline & Structural-Symbolic & 0 & 0 \\
\hline & Human Resource-Political & 2 & 2.2 \\
\hline & Human Resource-Symbolic & 2 & 2.2 \\
\hline & Political-Symbolic & 1 & 1.1 \\
\hline & Total & 23 & 24.7 \\
\hline \multirow[t]{5}{*}{ Multi-Frame } & Structural-Human Resource-Political & 5 & 5.4 \\
\hline & Structural-Human Resource-Symbolic & 5 & 5.4 \\
\hline & Human Resource-Political-Symbolic & 1 & 1.1 \\
\hline & Four-Frames & 25 & 26.9 \\
\hline & Total & 36 & 38.7 \\
\hline
\end{tabular}


Conflict management styles. The mean responses for the five conflict management styles were tabulated as shown in Table 8 . Styles with the highest averages were considered the predominant conflict management styles. The integrating conflict management style had the highest mean (4.3343) and it was followed by the compromising style (3.7681), the obliging style came third (3.3725) whereas the avoiding and the dominating styles were the least used conflict management styles (2.9313) and (2.9265) respectively. In comparing the education and business deans, although, both type of deans had the same sequence of conflict management styles, education deans had the highest mean for integrating style (4.4118) and the business deans scored a higher mean for the dominating conflict management style (3.0147). The mean scores for the obliging, avoiding, and compromising styles were almost equal for business and education deans.

In analyzing the variations in the conflict management styles, the standard deviations of the integrating, obliging, and compromising styles were modest with an average deviation of 0.5 and below; in comparison to the dominating and the avoiding conflict management styles which were slightly higher. 
Table 8

Conflict management styles of Business and Education deans in Masters Institutions

\begin{tabular}{llccccc}
\hline Name of College & Integrating & Obliging & Dominating & Avoiding & Compromising \\
\hline Business & Mean & 4.2227 & 3.3725 & 3.0147 & 2.9833 & 3.7500 \\
& Std. Dev & .52541 & .47462 & .60309 & .70569 & .41742 \\
Education & Mean & 4.4118 & 3.3724 & 2.8653 & 2.8952 & 3.7806 \\
& & & & & & \\
Total & Std. Dev & .43074 & .43405 & .77609 & .63995 & .56512 \\
& Mean & 4.3343 & 3.3725 & 2.9265 & 2.9313 & 3.7681 \\
& & & & & & \\
& & & & & & \\
\end{tabular}




\section{RQ2. Are there significant differences between Academic deans’ leadership frames,} styles, and conflict management styles in the context of type of college, gender, age, experience, or faculty size? Chi-Square analysis were done to identify if there are significant associations between deans' leadership frames and styles with type of college, gender, age, number of years as a dean, number of years in academia and faculty size. Categories such as age group and number of years as a dean were clustered into two groups instead of the initial three groups because of the small samples sizes in some of the categories. Table 9 shows the demographic frequencies of Academic dean's leadership frames. From the table, the structural and the human resources frames were used more frequently than the political and the symbolic frames across the board. It is also interesting to note that males scored higher on the structural $(62.1 \%)$ and the human resources frame $(80.3 \%)$; whereas, females scored slightly higher on the political (42.9\%) and the symbolic (38.1\%) frames. Deans with less than five years in the role of an academic dean scored higher percentages on all the leadership frames than deans with more than five years of experience as academic deans. More interesting to note is that deans with more than ten years of experience in academia scored high on the structural $(60.5 \%)$ and human resource frames (79.1\%) and low on political (39.5\%) and symbolic frames $(38.4 \%)$.

The study also showed that half of the deans who headed medium faculty size had a symbolic leadership frame. Although, relatively fewer in number than the deans with large faculty sizes, the deans with less than 40 members of faculty scored higher percentages in the human resources, political, and symbolic frames and slightly lower on the structural frame than their counterparts. 
Table 9

Demographic frequencies of Academic deans' leadership frames

\begin{tabular}{|c|c|c|c|c|c|c|c|c|c|c|}
\hline \multirow[t]{2}{*}{ Variables } & \multirow[t]{2}{*}{ Categories } & \multirow[b]{2}{*}{$\mathbf{N}$} & & Iral & \multicolumn{2}{|c|}{$\begin{array}{c}\text { Human } \\
\text { Resources }\end{array}$} & \multicolumn{2}{|c|}{ Political } & \multicolumn{2}{|c|}{ Symbolic } \\
\hline & & & $\mathbf{N}$ & $\%$ & $\mathbf{N}$ & $\%$ & $\mathbf{N}$ & $\%$ & $\mathbf{N}$ & $\%$ \\
\hline Name of College & Business & 37 & 21 & 55.3 & 28 & 73.7 & 10 & 26.3 & 11 & 28.9 \\
\hline$(n=89)$ & Education & 51 & 34 & 66.7 & 43 & 84.3 & 25 & 49.0 & 23 & 45.1 \\
\hline \multirow{2}{*}{ Gender (n=87) } & Male & 66 & 41 & 62.1 & 53 & 80.3 & 25 & 37.9 & 25 & 37.9 \\
\hline & Female & 21 & 12 & 57.1 & 16 & 76.2 & 9 & 42.9 & 8 & 38.1 \\
\hline Age Group & Below 60 years & 49 & 30 & 61.2 & 38 & 77.5 & 17 & 34.7 & 20 & 40.8 \\
\hline$(n=87)$ & Over 60 years & 38 & 23 & 60.5 & 31 & 81.6 & 18 & 47.4 & 14 & 36.8 \\
\hline Size of Faculty & Medium ( $\leq 40$ members) & 18 & 11 & 61.1 & 15 & 83.3 & 8 & 44.4 & 9 & 50.0 \\
\hline$(n=89)$ & Large ( $\geq 41$ members) & 71 & 44 & 62.0 & 56 & 78.9 & 27 & 38.0 & 25 & 35.2 \\
\hline No. of years as & Five years or less & 38 & 27 & 71.1 & 34 & 89.5 & 16 & 42.1 & 15 & 39.5 \\
\hline dean $(n=89)$ & More than Five years & 51 & 28 & 54.9 & 37 & 72.5 & 19 & 37.3 & 19 & 37.3 \\
\hline No. of years in & Between Five and Ten years & 3 & 3 & 100 & 3 & 100 & 1 & 33.3 & 1 & 33.3 \\
\hline academia $(n=89)$ & More than Ten years & 86 & 52 & 60.5 & 68 & 79.1 & 34 & 39.5 & 33 & 38.4 \\
\hline
\end{tabular}


Figure 3 shows the Chi-Square statistics for each of the category with the deans' leadership frames. For categories that had a frequency of less than five observations per cell; Phi, an alternative symmetric measure was used because it does not require the Chi-Square assumption that all cells should have at least five observations in each cell.

Based on the Chi-Square analysis on Table 10, there was a significant association between the name of the college and whether or not a dean had a political leadership frame $\chi(1)$ $=4.33, \mathrm{p}<0.05$. Although the odds ratio indicate that an education dean is 2.59 times more likely to have a political leadership frame than a business dean; the tabulations show that the number of deans without the political frame in the two colleges is almost equal. Similarly, there was a small significant relationship between the number of years served as a dean and whether or not the dean had a human resource leadership frame: $\chi(1)=3.866, p<0.05$ (Table 11). Based on the odds ratio, a dean with less than five years of experience as a dean was 3.23 times more likely to have a human resource frame than a dean with more than five years of experience as an academic dean. However, there were no significant associations between deans' leadership frames with gender, age, faculty size, or number of years in academia.

Similar analyses were conducted to find out if there are significant associations between deans' leadership styles with the six demographic variables. Table 12 shows the demographic frequencies of academic deans' leadership styles. From the table, the multi-frame leadership style was the most frequently used style by the deans across the board; followed by the paired frame, single frame and the least used method was the no frame leadership style. Almost half of the education deans used the multi-frame leadership style (47.2\%) compared to the business deans who only had $27.5 \%$ of the deans use the style. 


\begin{tabular}{|c|c|c|c|c|c|c|c|c|c|c|c|c|}
\hline \multirow[t]{2}{*}{ Variables } & \multicolumn{3}{|c|}{ Structural } & \multicolumn{3}{|c|}{ Human Resource } & \multicolumn{3}{|c|}{ Political } & \multicolumn{3}{|c|}{ Symbolic } \\
\hline & $\begin{array}{l}\text { Person } \\
\text { Chi- } \\
\text { Square }\end{array}$ & Df & $\begin{array}{l}\text { Asymp. } \\
\text { Sig. (2- } \\
\text { sided) }\end{array}$ & Value & Df & $\begin{array}{l}\text { Asymp. } \\
\text { Sig. (2- } \\
\text { sided) }\end{array}$ & Value & Df & $\begin{array}{l}\text { Asymp. } \\
\text { Sig. (2- } \\
\text { sided) }\end{array}$ & Value & df & $\begin{array}{l}\text { Asymp. } \\
\text { Sig. (2- } \\
\text { sided) }\end{array}$ \\
\hline Name of College & 1.199 & 1 & 0.273 & 1.525 & 1 & 0.217 & 4.33 & 1 & $0.037^{*}$ & 2.136 & 1 & 0.144 \\
\hline Gender & 0.166 & 1 & 0.684 & $\begin{array}{c}\begin{array}{c}\text { Phi- } \\
\text { Square }\end{array} \\
0.043\end{array}$ & & 0.685 & 0.128 & 1 & 0.72 & 0.001 & 1 & 0.976 \\
\hline Age & 0.004 & 1 & 0.947 & 0.212 & 1 & 0.646 & 1.255 & 1 & 0.263 & 0.207 & 1 & 0.65 \\
\hline Size of faculty & 0.005 & 1 & 0.946 & $\begin{array}{c}\text { Phi- } \\
\text { Square } \\
-0.045\end{array}$ & & 0.674 & 0.206 & 1 & 0.65 & 1.232 & 1 & 0.267 \\
\hline $\begin{array}{c}\text { No. of years as } \\
\text { dean }\end{array}$ & 2.406 & 1 & 0.121 & 3.866 & 1 & $0.049 *$ & 0.321 & 1 & 0.571 & 0.098 & 1 & 0.755 \\
\hline $\begin{array}{c}\text { No. of years in } \\
\text { academia }\end{array}$ & $\begin{array}{c}\begin{array}{c}\text { Phi- } \\
\text { Square }\end{array} \\
-0.147\end{array}$ & & 0.166 & $\begin{array}{c}\text { Phi- } \\
\text { Square } \\
-0.094\end{array}$ & & 0.375 & $\begin{array}{c}\begin{array}{c}\text { Phi- } \\
\text { Square }\end{array} \\
0.025\end{array}$ & & 0.817 & $\begin{array}{c}\begin{array}{c}\text { Phi- } \\
\text { Square }\end{array} \\
0.02\end{array}$ & & 0.848 \\
\hline
\end{tabular}


Table 10

Type of college and the political frame

\begin{tabular}{|c|c|c|c|c|c|}
\hline $\begin{array}{l}\text { Type of } \\
\text { college }\end{array}$ & $\begin{array}{c}\text { With a } \\
\text { political } \\
\text { frame }\end{array}$ & $\begin{array}{c}\text { Without a } \\
\text { political } \\
\text { frame }\end{array}$ & Total & $X$ & Odds Ratio \\
\hline Business & 10 & 27 & 37 & $4.330 *$ & 0.39 \\
\hline Education & 25 & 26 & 51 & & 2.59 \\
\hline Total & 35 & 53 & 88 & & \\
\hline
\end{tabular}

Note: Chi-Square analysis and odds ratio of type of college and political frame $* \mathrm{p}<0.05$

Table 11

Number of years as a dean and the human resource frame

\begin{tabular}{cccccc}
\hline $\begin{array}{c}\text { No. of years } \\
\text { as a dean }\end{array}$ & $\begin{array}{c}\text { With a } \\
\text { human } \\
\text { resource } \\
\text { frame }\end{array}$ & $\begin{array}{c}\text { Without a } \\
\text { human } \\
\text { resource } \\
\text { frame }\end{array}$ & Total & $\boldsymbol{X}$ & Odds Ratio \\
\hline <5 years & 34 & 4 & 38 & $3.866^{*}$ & 3.23 \\
$>$ 5 years & 37 & 14 & 51 & & 0.31 \\
Total & 71 & 18 & 89 & & \\
& & & & &
\end{tabular}

Note: Chi-Square analysis and odds ratio of number of years as a dean and human resource frame

$* \mathrm{p}<0.05$ 
Table 12

Demographic frequencies of Academic deans' leadership styles

\begin{tabular}{|c|c|c|c|c|c|c|c|c|c|c|}
\hline \multirow[t]{2}{*}{ Variables } & \multirow[t]{2}{*}{ Categories } & \multirow[t]{2}{*}{$\mathbf{N}$} & \multicolumn{2}{|c|}{ No-Frame } & \multicolumn{2}{|c|}{ Single Frame } & \multicolumn{2}{|c|}{ Paired Frame } & \multicolumn{2}{|c|}{ Multi-Frame } \\
\hline & & & $\mathbf{N}$ & $\%$ & $\mathbf{N}$ & $\%$ & $\mathbf{N}$ & $\%$ & $\mathbf{N}$ & $\%$ \\
\hline Name of & Business & 40 & 8 & 20 & 8 & 20 & 11 & 27.5 & 11 & 27.5 \\
\hline College $(n=93)$ & Education & 53 & 6 & 11 & 8 & 15.1 & 12 & 22.6 & 25 & 47.2 \\
\hline \multirow{2}{*}{ Gender $(n=86)$} & Male & 65 & 11 & 16.9 & 11 & 16.9 & 17 & 26.2 & 27 & 41.5 \\
\hline & Female & 21 & 3 & 14.3 & 5 & 23.8 & 5 & 23.8 & 8 & 38.1 \\
\hline \multirow{2}{*}{ Age Group } & Below 60 years & 52 & 8 & 15.4 & 7 & 13.5 & 15 & 28.8 & 19 & 36.5 \\
\hline & Over 60 years & 39 & 6 & 15.4 & 9 & 23.1 & 6 & 15.4 & 17 & 43.6 \\
\hline \multirow{2}{*}{$\begin{array}{l}\text { Size of Faculty } \\
\qquad(n=89)\end{array}$} & $\begin{array}{c}\text { Medium }(\leq 40 \\
\text { members })\end{array}$ & 18 & 2 & 11 & 5 & 27.8 & 2 & 11.1 & 9 & 50.0 \\
\hline & $\begin{array}{c}\text { Large }(\geq 41 \\
\text { members })\end{array}$ & 71 & 12 & 17 & 11 & 15.5 & 21 & 29.6 & 27 & 38.0 \\
\hline \multirow{2}{*}{$\begin{array}{c}\text { No. of years as } \\
\text { dean }(n=89)\end{array}$} & $\begin{array}{c}\text { Five years or } \\
\text { less }\end{array}$ & 38 & 3 & 8 & 6 & 15.8 & 12 & 31.6 & 17 & 44.7 \\
\hline & $\begin{array}{l}\text { More than Five } \\
\text { years }\end{array}$ & 51 & 11 & 22 & 10 & 19.6 & 11 & 21.6 & 19 & 37.3 \\
\hline \multirow{2}{*}{$\begin{array}{l}\text { No. of years in } \\
\text { academia }\end{array}$} & $\begin{array}{l}\text { Between Five } \\
\text { and Ten years }\end{array}$ & 3 & 0 & 0 & 0 & 0 & 1 & 33.3 & 2 & 66.7 \\
\hline & $\begin{array}{l}\text { More than Ten } \\
\text { years }\end{array}$ & 90 & 14 & 15.6 & 16 & 17.8 & 22 & 24.4 & 34 & 37.8 \\
\hline
\end{tabular}


In analyzing table twelve it is important to note that half of the deans heading a medium faculty size, less than 40 but more than 20 faculty members, used the multi-frame leadership style. Also interesting to note is that although more than half of the deans had more than five years of experience as academic deans; almost half of those with five years or less in the role of academic dean had a multi-frame leadership style (44.7\%).

Figure 4 shows the Chi-Square statistics for each of the category with the deans' leadership styles. For categories that had a frequency of less than five observations per cell, Phi Square, an alternative symmetric measure was used because it does not require the Chi-Square assumption that all cells should have at least five observations in each cell. From the analysis, there were close non-significant associations between the name of the college and whether or not a dean was multi-framed $\chi(1)=3.717, p>0.05$; with a $p$-value of 0.054 and between the number of years an academic dean had served as a dean and no frame leadership style $\chi(1)=3.132$, $\mathrm{p}>0.05$; with a $\mathrm{p}$-value of 0.077 . However, there were no significant associations between dean's leadership styles with gender, age, faculty size, and number of years in academia.

In analyzing if there are significant differences between deans' conflict management styles and the six demographic factors; the Mann-Whitney test was performed as an alternative to the t-test statistic. Table 13 shows the results of the Mann-Whitney test for conflict management styles with type of college, gender, age, faculty size, number of years as an academic dean and number of years in academia. Considering that a significant difference was found between the number of years in academia and the compromising conflict management style; Table 14 shows the mean rank and effect size of the two variables. 
Relationship between Leadership Styles and various demographic variables

Figure 4. Associations between Academic deans' leadership styles and demographic information

\begin{tabular}{|c|c|c|c|c|c|c|c|c|c|c|c|c|}
\hline \multirow[t]{2}{*}{ Variables } & \multicolumn{3}{|c|}{ No-Frame } & \multicolumn{3}{|c|}{ Single Frame } & \multicolumn{3}{|c|}{ Paired Frame } & \multicolumn{3}{|c|}{ Multi-Frame } \\
\hline & $\begin{array}{c}\text { Person } \\
\text { Chi- } \\
\text { Square }\end{array}$ & Df & $\begin{array}{l}\text { Asymp. } \\
\text { Sig. (2- } \\
\text { sided) }\end{array}$ & Value & Df & $\begin{array}{c}\text { Asymp. } \\
\text { Sig. (2- } \\
\text { sided) }\end{array}$ & Value & Df & $\begin{array}{l}\text { Asymp. } \\
\text { Sig. (2- } \\
\text { sided) }\end{array}$ & Value & df & $\begin{array}{l}\text { Asymp. } \\
\text { Sig. (2- } \\
\text { sided) }\end{array}$ \\
\hline $\begin{array}{c}\text { Name of } \\
\text { College }\end{array}$ & 1.343 & 1 & .247 & .385 & 1 & .535 & .289 & 1 & .591 & 3.717 & 1 & .054 \\
\hline Gender & $\begin{array}{l}\begin{array}{l}\text { Phi } \\
\text { Square } \\
.027\end{array}\end{array}$ & & .794 & $\begin{array}{l}\begin{array}{l}\text { Phi } \\
\text { Square }\end{array} \\
-.076\end{array}$ & & .467 & .033 & 1 & .855 & .054 & 1 & .816 \\
\hline Age & 0.000 & 1 & 1.000 & 1.422 & 1 & .233 & 2.275 & 1 & .131 & .463 & 1 & .496 \\
\hline Size of faculty & $\begin{array}{l}\text { Phi } \\
\text { Square } \\
.074\end{array}$ & & .476 & $\begin{array}{l}\text { Phi } \\
\text { Square } \\
-.108\end{array}$ & & .297 & $\begin{array}{l}\text { Phi } \\
\text { Square } \\
.179\end{array}$ & & .085 & .425 & 1 & .514 \\
\hline $\begin{array}{c}\text { No. of years as } \\
\text { dean }\end{array}$ & 3.132 & 1 & 0.077 & .239 & 1 & .625 & 1.047 & 1 & .306 & .425 & 1 & .514 \\
\hline $\begin{array}{c}\text { No. of years in } \\
\text { academia }\end{array}$ & $\begin{array}{l}\text { Phi } \\
\text { Square } \\
.077\end{array}$ & & .459 & $\begin{array}{l}\text { Phi } \\
\text { Square } \\
.083\end{array}$ & & .422 & $\begin{array}{l}\text { Phi } \\
\text { Square } \\
-.036\end{array}$ & & .726 & $\begin{array}{l}\text { Phi } \\
\text { Square } \\
-.105\end{array}$ & & .312 \\
\hline
\end{tabular}

Figure 4. Chi-Square statistics for demographic variables and leadership styles. For categories with a frequency of less than five observations per cell; Phi-Square analysis was used. ${ }^{*} \mathrm{p}<0.05$ 
Table 13

Differences between Academic deans' conflict management styles and demographic variables

\begin{tabular}{|c|c|c|c|c|c|c|c|c|c|c|c|c|c|c|c|}
\hline & \multicolumn{3}{|c|}{ Integrating } & \multicolumn{3}{|c|}{ Obliging } & \multicolumn{3}{|c|}{ Dominating } & \multicolumn{3}{|c|}{ Avoiding } & \multicolumn{3}{|c|}{ Compromising } \\
\hline & $\mathbf{U}$ & $\mathbf{Z}$ & Sig. & $\mathbf{U}$ & $\mathbf{Z}$ & Sig. & $\mathbf{U}$ & $\mathbf{Z}$ & Sig. & $\mathbf{U}$ & $\mathbf{Z}$ & Sig. & $\mathbf{U}$ & $\mathbf{Z}$ & Sig. \\
\hline $\begin{array}{l}\text { Name of } \\
\text { college }\end{array}$ & 672 & -1.502 & 0.13 & 795 & -0.35 & 0.73 & 757.5 & -0.702 & 0.48 & 797.5 & -0.33 & 0.74 & 812.5 & -0.194 & 0.847 \\
\hline Gender & 482.5 & -1.196 & 0.23 & 567 & -0.247 & 0.81 & 548 & -0.459 & 0.65 & 429.5 & -1.785 & 0.07 & 568 & -0.239 & 0.811 \\
\hline Age & 748.5 & -0.653 & 0.51 & 707 & -1.049 & 0.29 & 657.5 & -1.515 & 0.13 & 735 & -0.779 & 0.44 & 797.5 & -0.188 & 0.851 \\
\hline $\begin{array}{l}\text { Size of } \\
\text { faculty }\end{array}$ & 527.5 & -0.381 & 0.7 & 490 & -0.807 & 0.42 & 463.5 & -1.104 & 0.27 & 556 & -0.057 & 0.96 & 522 & -0.449 & 0.654 \\
\hline $\begin{array}{l}\text { No. of } \\
\text { years as } \\
\text { dean }\end{array}$ & 751.5 & -0.875 & 0.38 & 829 & -0.157 & 0.88 & 717 & -1.19 & 0.23 & 652.5 & -1.785 & 0.07 & 724 & -1.143 & 0.253 \\
\hline $\begin{array}{c}\text { No. of } \\
\text { years in } \\
\text { academia }\end{array}$ & 53 & -1.647 & 0.11 & 54 & -1.622 & 0.12 & 108 & -0.294 & 0.79 & 87.5 & -0.796 & 0.45 & 32.5 & -2.177 & $0.027 *$ \\
\hline
\end{tabular}

Note. Mann-Whitney U Statistic for demographic variables and conflict management styles. ${ }^{*} \mathrm{p}<0.05$ 
Table 14

Compromising conflict management style and number of years in academia

\begin{tabular}{cccccc}
\hline $\begin{array}{c}\text { Conflict } \\
\text { management style }\end{array}$ & $\begin{array}{c}\text { No. of years } \\
\text { in } \\
\text { academia }\end{array}$ & N & Mean Rank & U & Effect size \\
\hline $\begin{array}{c}\text { Compromising } \\
\text { conflict }\end{array}$ & $5-10$ years & 3 & 71.17 & $32.500^{*}$ & -.24 \\
management style & $\begin{array}{c}\text { More than } \\
10 \text { years }\end{array}$ & 80 & 40.91 & \\
\hline
\end{tabular}

Note: Mann-Whitney U test of compromising conflict management style and number of years in academia

${ }^{*} \mathrm{p}<0.05$ 
The results of Table 14 indicate that there is a significant difference between academic deans' number of years in academia and the use of the compromising conflict management style, $\mathrm{U}=32.50, \mathrm{p}<0.05, \mathrm{r}=-.24$. The negative effect size indicates that deans with more than ten years of experience in academia were more likely to use the compromising conflict management style than deans with less years of experience. However, the effect size is small because it is below the .3 criterion for a medium effect size (Field, 2005). There were however no significant differences between academic deans' conflict management styles with name of college, gender, age group, size of faculty, and number of years as a dean.

\section{RQ3. Are there significant relationships between academic deans' leadership}

frames, leadership styles, and conflict management styles? Spearman Rho correlations were used to identify if there were significant relationships between the deans leadership frames, styles, and conflict management styles. This type of analysis is identified to be the most appropriate because, the data set is ordinal and it violated the assumptions of parametric tests

This research question was analyzed in three parts: relationship between leadership frames and leadership styles (Table 15); leadership frames and conflict management styles (Table 16); and leadership styles and conflict management styles (Table 17). From the analysis on Table 12 there were significant relationships between all the four leadership frames: Structural frame was positively related to the human resource frame $r_{s}(89)=.51, p<0.01$; Political Frame $r_{s}(88)=.41, p<0.01$; and Symbolic frame $r_{s}(88)=.44, p<0.01$. The Human resource frame was positively related to the political frame $r_{s}(88)=.30, p<0.01$ and to the symbolic frame $\mathrm{r}_{\mathrm{s}}(88)=.35, \mathrm{p}<0.01$ whereas, the political frame was positively related to the symbolic frame $\mathrm{r}_{\mathrm{s}}(88)=.64, \mathrm{p}<0.01$. 
Table 15

Correlations between leadership frames and leadership styles

\begin{tabular}{|c|c|c|c|c|c|c|c|c|c|}
\hline & & Structural & $\begin{array}{c}\text { Human } \\
\text { Resource }\end{array}$ & Political & Symbolic & $\begin{array}{c}\text { No } \\
\text { Frame }\end{array}$ & $\begin{array}{l}\text { Single } \\
\text { Frame }\end{array}$ & $\begin{array}{l}\text { Paired } \\
\text { Frame } \\
\end{array}$ & $\begin{array}{l}\text { Multi- } \\
\text { Frame }\end{array}$ \\
\hline \multirow{9}{*}{$\begin{array}{l}\text { Spearman's } \\
\text { rho }\end{array}$} & Structural & & & & & & & & \\
\hline & Human & $.525^{* *}$ & & & & & & & \\
\hline & Resource & & & & & & & & \\
\hline & Political & $.406^{* *}$ & $.297^{* *}$ & & & & & & \\
\hline & Symbolic & $.438^{* *}$ & $.345^{* *}$ & $.643^{* *}$ & & & & & \\
\hline & No Frame & $-.550^{* *}$ & $-.858^{* *}$ & $-.353^{* *}$ & $-.345^{* *}$ & & & & \\
\hline & Single Frame & $-.475^{* *}$ & 0.017 & $-.323^{* *}$ & $-.374^{* *}$ & -0.192 & & & \\
\hline & Paired Frame & 0.2 & $.233^{*}$ & $-.308^{* *}$ & $-.296^{* *}$ & $-.241^{*}$ & $-.261^{*}$ & & \\
\hline & Multi-Frame & $.601^{* *}$ & $.415^{* *}$ & $.788^{* *}$ & $.811^{* *}$ & $-.335^{* *}$ & $-.362^{* *}$ & $-.456^{* *}$ & \\
\hline
\end{tabular}


Among the leadership frames and leadership styles; there were significant negative relationships between the no-frame leadership style with all the four leadership frames: structural frame; $\mathrm{r}_{\mathrm{s}}(89)=-.55, \mathrm{p}<0.01$; human resource frame; $\mathrm{r}_{\mathrm{s}}(89)=-.86, \mathrm{p}<0.01 ;$ political frame; $\mathrm{r}_{\mathrm{s}}(88)=-.35, \mathrm{p}<0.01 ;$ and symbolic frame; $\mathrm{r}_{\mathrm{s}}(88)=-.35, \mathrm{p}<0.01$ and positive significant relationships between the four frames of leadership with the multi-frame leadership style: structural $\mathrm{r}_{\mathrm{s}}(89)=.6, \mathrm{p}<0.01$; human resource $\mathrm{r}_{\mathrm{s}}(89)=.42, \mathrm{p}<0.01$; political $\mathrm{r}_{\mathrm{s}}(88)=.79$, $\mathrm{p}<0.01$; and symbolic $\mathrm{r}_{\mathrm{s}}(88)=.81, \mathrm{p}<0.05$. The single frame leadership style was negatively related to the structural $\mathrm{r}_{\mathrm{s}}(89)=-.48, \mathrm{p}<0.01$; political $\mathrm{r}_{\mathrm{s}}(88)=-.32, \mathrm{p}<0.01$; and the symbolic $\mathrm{r}_{\mathrm{s}}(88)=-.37, \mathrm{p}<0.01$ leadership frames. This means that respondents with structural, symbolic and political frames were least likely to have a single frame of leadership. Corresponding to the preceding finding, the paired frame leadership style was positively related to the human resource frame $r_{s}(89)=.23, p<0.01$ and negatively related to the political $r_{s}(88)=-.31, p<0.01$; and symbolic $\mathrm{r}_{\mathrm{s}}(88)=-.30, \mathrm{p}<0.01$ frames. As could be expected, there were negative significant and non-significant relationships among the four leadership styles: no-frame, single frame, paired frame and multi-frame. Table 16 shows the correlations between leadership frames and conflict management styles. 


\section{Human}

Structural Resource Political Symbolic Integrating Obliging Dominating Avoiding Compromising

Spearman's Structural
rho

\begin{tabular}{|c|c|c|c|c|c|c|c|}
\hline $\begin{array}{l}\text { Human } \\
\text { Resource }\end{array}$ & $.525^{* *}$ & & & & & & \\
\hline Political & $.406^{* *}$ & $.297^{* *}$ & & & & & \\
\hline Symbolic & $.438^{* *}$ & $.345^{* *}$ & $.643^{* *}$ & & & & \\
\hline Integrating & $.234^{*}$ & $.321^{* *}$ & $.366^{* *}$ & $.282^{* *}$ & & & \\
\hline Obliging & -0.031 & -0.108 & 0.08 & 0.091 & $.258^{*}$ & & \\
\hline Dominating & -0.142 & $-.278^{*}$ & -0.052 & -0.095 & $-.277^{*}$ & 0.131 & \\
\hline Avoiding & -0.018 & -0.061 & -0.04 & 0.074 & 0.013 & $.264^{*}$ & 0.146 \\
\hline Compromising & -0.05 & -0.018 & -0.004 & -0.168 & $.341^{* *}$ & $.407^{* *}$ & 0.006 \\
\hline
\end{tabular}

Correlations between leadership frames and conflict management styles

$* * p<0.01$ 
The analyses on Table 16 show that there were some significant relationships between the leadership frames and conflict management styles. The integrating conflict management style was positively related to all the four leadership frames: Structural $r_{s}(83)=.23, p<0.05$; human resources $\mathrm{r}_{\mathrm{s}}(83)=.32, \mathrm{p}<0.01$; political $\mathrm{r}_{\mathrm{s}}(83)=.37, \mathrm{p}<0.01$; and the symbolic $\mathrm{r}_{\mathrm{s}}(83)=$ $.28, \mathrm{p}<0.01$. Whereas, there was a negative relationship between the dominating conflict management style and the human resource frame $r_{s}(83)=-.28, p<0.05$. There were no other significant relationships between the obliging, avoiding, and compromising conflict management styles with the four frames of leadership.

Among the conflict management styles, the integrating conflict management style was positively related with the obliging $r_{s}(83)=.26, p<0.05$ and the compromising $r_{s}(83)=.34$, $\mathrm{p}<0.01$ conflict management styles and negatively related with the dominating $\mathrm{r}_{\mathrm{s}}(83)=-.28$, $\mathrm{p}<0.05$ conflict management style. The obliging conflict management style was positively related to the avoiding $r_{s}(83)=.26, p<0.05$ and the compromising $r_{s}(83)=.23, p<0.05$ conflict management styles. Whereas, the compromising conflict management style was positively related to the integrating $\mathrm{r}_{\mathrm{s}}(83)=.34, \mathrm{p}<0.01$; obliging $\mathrm{r}_{\mathrm{s}}(83)=.41, \mathrm{p}<0.01$; and the avoiding $\mathrm{r}_{\mathrm{s}}(83)=.23, \mathrm{p}<0.05$ conflict management styles.

Table 17 shows the correlations between the leadership styles: No-frame, single frame, paired-frame, and multi-frame with the conflict management styles: Integrating, obliging, dominating, avoiding, and compromising. From the result, among all the five conflict management styles, significant relationships were only found with the integrating conflict management style. The integrating conflict management style was found to have a positive significant relationship with the multi-frame leadership style $\mathrm{r}_{\mathrm{s}}(83)=.34, \mathrm{p}<0.05$ and a negative significant relationship with the no-frame leadership style $r_{s}(83)=-.33, p<0.01$. 
Table 17

Correlations between leadership styles and conflict management styles

\begin{tabular}{|c|c|c|c|c|c|c|c|c|c|c|}
\hline & & No & Single & Paired & Multi- & & & & & \\
\hline & & Frame & Frame & Frame & Frame & Integrating & Obliging & Dominating & Avoiding & Compromising \\
\hline Spear & No Frame & & & & & & & & & \\
\hline man's & Single Frame & -0.192 & & & & & & & & \\
\hline \multirow[t]{7}{*}{ rho } & Paired Frame & $-.241^{*}$ & $-.261^{*}$ & & & & & & & \\
\hline & Multi-Frame & $-.335^{* *}$ & $-.362^{* *}$ & $-.456^{* *}$ & & & & & & \\
\hline & Integrating & $-.334^{* *}$ & -0.107 & 0.1 & $.255^{*}$ & & & & & \\
\hline & Obliging & 0.073 & -0.087 & 0.008 & 0.007 & $.258^{*}$ & & & & \\
\hline & Dominating & 0.198 & -0.094 & 0.102 & -0.166 & $-.277^{*}$ & 0.131 & & & \\
\hline & Avoiding & -0.004 & 0.113 & -0.064 & -0.031 & 0.013 & $.264^{*}$ & 0.146 & & \\
\hline & Compromising & -0.045 & 0.058 & 0.13 & -0.13 & $.341^{* *}$ & $.407^{* *}$ & 0.006 & $.225^{*}$ & \\
\hline
\end{tabular}




\section{Summary}

This chapter presented the results of the leadership orientations and conflict management styles of academic deans heading colleges of business and education in master's institutions. Bolman and Deal's leadership orientation (LOI- self) and Rahim Organizational Conflict Inventory (ROCI-II) instruments were sent to 247 academic deans. Ninety three deans responded to the survey yielding a response rate of $37.6 \%$.

Three research questions were analyzed. The statistical analysis used to analyze the research questions included frequencies, means, standard deviations, Chi-Square analysis, MannWhitney U- tests, and Spearman Rho correlations. From the analysis, the academic deans scored high mean responses on all the four frames with the human resources frame being the most frequently used. The multi-frame leadership style was also most the predominant style among the deans and the no-frame leadership style was the least frequently used. In analyzing the conflict management styles; the integrating conflict management style was the most frequently used style followed by the compromising and obliging conflict management styles. The dominating and avoiding conflict management styles were rarely used.

In analyzing the second research question, the Chi-Square analysis revealed that there were significant associations between the name of the college and the use of the political leadership frames. An education dean was 2.59 times more likely to use the political frame than the business deans. The results also indicated a significant relationship between the number of years as a dean and the use of the human resources frame. Deans with less than five years of experience in the position of an academic dean were 3.23 times more likely to have a human resource frame than deans with more experience in the position. The results from the MannWhitney U test also showed that there was a significant difference between academic deans' 
number of years in academia and the use of the compromising conflict management style. Deans with more than ten years of experience in academia were more likely to use the compromising conflict management styles with an effect size of .24 than deans with less experience in the field. In analyzing the third research question, there were significant relationships between the leadership frames, styles, and conflict management styles. The integrating conflict management style was positively related to all the leadership frames. Contrary to this, the dominating conflict management style was negatively related to the human resources frame. In evaluating the leadership styles and conflict management styles; the integrating conflict management style was positively related to the multi-frame leadership style and negatively related to the no-frame leadership style. There were no significant relationships between the other conflict management styles with the leadership frames and styles. 


\section{Chapter V}

\section{Summary, Discussions, Conclusions, and Recommendations}

This chapter provides a summary of the purpose of the study, discussion of the research findings, recommendations for practice and future research and the conclusion of the study.

\section{Summary of the Study}

According to the literature, academic deans by legitimacy of their position as academic leaders and administrators (Martin, 1993; M. Wolverton \& Gmelch, 2002) have a role to intervene in organizational conflicts and their leadership orientation could influence the choice and effectiveness of their conflict management style. Previous research show that academic deans follow either structural or human relations approaches when dealing with conflict (Feltner \& Goodsell, 1972). However, these two approaches to handling conflict are considered insufficient because they are oblivious of the political and the symbolic cognitive theories that are essential in evaluating conflict management styles. This research therefore aimed at adding to the existing literature by evaluating the relationship between deans' conflict management styles with the four leadership orientations: Structural, human resources, political, and symbolic.

This study used the constructs of Bolman and Deal in evaluating leadership orientations and Rahim Organizational Conflict Inventory (ROCI-II) in evaluating conflict management styles. According to Bolman and Deal (2003) there are four major perspectives that leaders use to understand their organizations. The four perspectives which they labeled as frames refer to "windows, tools, lenses, orientations, perspectives" (p.12) that leaders use to make sense of their organizations. They identified the four frames to be structural, human resources, political, and symbolic. The combination of, or lack of, the four frames make up the leadership styles; leaders with no predetermined leadership frame are classified as having a no-frame leadership style, 
those with one frame are identified as having single frame style, those with two frames as paired frame style, and those with at least three of the frames are multi-frame. On the other hand, Rahim (1983) identified conflict management styles to range from "concern for self" to "concern for others". He classified the conflict management styles as integrating, obliging, compromising, dominating, and avoiding. Categories with the highest mean scores are considered the predominant conflict management styles. The ROCI-II was selected for the study because it highlights on the effects of a person's disposition in choosing a conflict management style (Weider-Hatfield, 1988).

The study evaluated academic deans heading business and education colleges in Public Master's Degree Institutions-Larger programs and it used a quantitative research design. The leadership frames and styles of the deans were measured using Bolman and Deal's leadership orientation instrument (LOI-Self) (see Appendix F, section B for instrument) while the conflict management styles were evaluated using Rahim Organizational Conflict Inventory (ROCI-II) (see Appendix F, section C for instrument). Both instruments were preceded by a demographic section which included questions on dean's gender, name of college, faculty size, number of years as a dean, and number of years in academia (see Appendix F, section A for questions).

\section{Discussion of the Research Findings}

The following research questions were evaluated in this research: RQ1. What leadership frames, styles, and conflict management styles do Academic deans in Public Masters Colleges and Universities demonstrate? RQ2. Are there significant differences between deans' leadership frames, styles and conflict management styles in the context of gender, experience, faculty size or type of college? RQ3. Are there significant relationships between deans' leadership frames, styles and conflict management styles? 
Demographic section. The results revealed that $57 \%$ of the respondents belonged to the colleges of education while $43 \%$ belonged to the colleges of business. Male respondents were the majority (74.2\%); most of the deans were below sixty years of age $(56 \%)$ and had worked in the position of the dean for more than five years (57\%). Majority of the deans has served in academia for more than ten years $(96.8 \%)$ and had more than forty members of faculty in their colleges (78.5\%). This finding coincides with Cantu (1997) survey of random and nominated academic deans that found most of the deans to be male, $73.8 \%$ in the random selection and $76 \%$ in the nominated selection, had an average age of 54.1; had at least seven years of experience in the deans' position and had supervised more than a hundred members of faculty. Way (2010) did a study on leadership styles of academic deans in various disciplines and found that the female deans consisted of $35 \%$ of the sample; deans had served in their current institution for 14.11years, and a majority had served in the current role of the dean for more than seven years $(33 \%)$.

RQ1. What leadership frames, styles, and conflict management styles do Academic deans in Masters Colleges and Universities demonstrate? Academic deans in both business and education colleges demonstrated the human resources frame most frequently (4.3) and the symbolic (3.85) and political frames (3.82) least frequently. This finding is consistent with Cantu (1997) research which showed that among the random and nominated deans, the human resources frame was the most dominant style with a mean of 4.21 and the political and symbolic frames were the least used styles with means of 3.79 and 3.73 respectively.

The study also found the multi-frame leadership style to be the most frequently used style and the no-frame to be the least frequently used style. An interesting finding was that almost half of the academic deans in the colleges of education had a multi-frame leadership style a number 
which was almost twice the number of deans with a multi-frame leadership style in the colleges of business. This finding contradicts Bolman and Deal (1991a) research that found leaders rarely used more than two frames and hardly used all the four frames. More specifically, Bolman and Deal found the percentage of leaders with more than two frames was less than $25 \%$ and those with all the frames was less than $1 \%$. Contrary to this inference, the current study showed that more than half of the respondents $(59.44 \%)$ had more than two frames and those with at least three of the frames were $38.71 \%$.

The study found that academic deans used the integrating conflict management style most frequently followed by the compromising style which was succeeded by the obliging style. The avoiding and dominating styles were the least frequently used styles among the deans. This sequence was similar for both the business and education deans; with the education deans scoring higher or equal means than the business deans in all the styles, but for the dominating and avoiding conflict management styles. This finding coincides with Donovan (1993) study that showed academic deans' sequence of conflict management styles as perceived by both the deans and their subordinates to be integrating, compromising, obliging, dominating, and avoiding. Woodtli (1987) did a similar study on nursing deans and found the compromising conflict management style to be the most frequently used, followed by collaborating (integrating), third was avoiding which was succeeded by accommodating (obliging) and finally the competing(dominating) style was the least frequently used. 
RQ2. Are there significant differences between Academic deans’ leadership frames, styles, and conflict management styles in the context of gender, experience, faculty size or type of college? The study found a significant association between the name of the college and whether or not a dean had a political frame. From the odds ratio calculation, an education dean is 2.59 times more likely to have a political frame than a business dean. However, it should be noted that the tabulations on deans' use of political frame show that the number of deans who indicated as not having the political frame is almost equal in the two colleges. Hence, it could be inferred that, rather than the education dean being more apt to use the political frame, the interpretation should be that a business dean is least likely to indicate espousing a political frame than an education dean. Comparative to this study a study by Cantu (1997) found that nominated deans scored significantly higher mean scores on the political frame than the randomly selected deans. Analogous to this finding, his study also found that effective health professional deans scored significantly higher mean scores on the political and symbolic frames than effective science oriented deans. Corresponding to the above studies, a study by Russell (2000) on community college deans found that additional experience or higher levels of scholarship since becoming a dean had positive correlations with the political and symbolic leadership frames.

Way (2010) did a similar study on the impact of academic deans' discipline on their organizational leadership styles and found significant relationships between the deans' academic discipline, race, gender, and number of years as a faculty member with the leadership frames and styles. It is important to note that Way did not use the Bolman and Deal framework to evaluate the leadership frames and styles; she developed her own instrument to measure the perspectives of bureaucratic, collegial, symbolic, and political frames which are similar to the structural, human resources, symbolic, and political frames. In her study, she categorized academic deans' 
disciplines into four clusters: Low applied fields which included disciplines in education and business among others; low pure fields with disciplines in psychology, sociology, and philosophy among others; high applied fields included disciplines in chemistry, and mathematics among others. From her study, the collegial frame, which is likened to the human resources frame, was positively correlated to the low applied disciplinary fields and negatively correlated to the high pure and low pure disciplines. Similar to Way's findings a study by Yerkes, M. Cueller, and A. Cuellar (1992), found that all academic disciplines in education colleges with an exception of history/foundation group espoused the human resource frame most frequently.

Other than type of college, the current study also showed significant differences between number of years as a dean and the human resources frame. Deans with less than five years of experience in the position of an academic dean were 3.23 times more likely to have a human resource frame than deans with more years in the position, it is also interesting to note that among the deans in the current study, deans with less experience scored higher mean scores on all the leadership frames than deans with more years of experience. Contrary to this finding, Cantu (1997) in his study on nominated and random deans found that deans with more than ten years of experience in the position of an academic dean were more likely to have a political frame than deans with less experience. Way (2010) correspondingly found the bureaucratic frame, which can be likened to the structural frame, to be negatively related to the number of years as a faculty member; deans with more years as faculty members had the least likelihood of demonstrating the bureaucratic frame. It can therefore be inferred that, deans with less experience are more likely to utilize the human resources frame, more than the deans with more experience, because as they assimilate in the college they will involve faculty and other members of college to give them support to meet their deanship goals. 
In analyzing the relationship between academic deans' demographic information with their leadership styles the study found close non-significant associations between the type of college with the multi-frame leadership style (p-value; 0.054$)$ and between number of years in the position of an academic dean with the no frame leadership style (p-value; 0.077). All the other demographic variables did not yield any significant associations with the multi-frame leadership style. This finding contrasts Way (2010) findings that revealed the paired and multiframe leadership styles to be negatively related with the female gender.

The current study found a significant difference between academic deans' number of years in academia and the use of compromising conflict management style. More specifically, deans with more than ten years of experience in academia were more likely to use the compromising conflict management style than deans with less than ten years of experience in academia. Similar to this finding, Cetin and Hacifazlioglo (2004) found that academics with 1120 years of experience were more likely to accommodate than those with less years of experience. It could therefore be inferred that the compromising conflict management style is more prevalent among deans with more experience because as deans get more acquainted to their deanship role; they realize that most issues do not have clear-cut answers and hence acknowledge the need to find a middle ground. However, both experienced and inexperienced deans need to be equipped with strategies to handle conflict through collaboration because as noted by Rahim (1983) the over reliance of the compromising conflict management style could yield dysfunctional outcomes. The current study, did not find any significant differences between gender, type of college, number of years as a dean and faculty size with a dean's choice of conflict management style.sac, 


\section{RQ3. Is there a significant relationship between Academic deans' leadership frames,} styles and conflict management styles? The findings of the current study showed that there were positive significant relationships between the four leadership frames and styles. All the four frames of leadership were positively related to the multi-frame leadership style and negatively related to the no frame leadership style. The single frame leadership style was negatively related to the structural, political, and symbolic frames; implying that an academic dean was least likely to display the structural, symbolic, and political frame independently. In the same way, the paired frame was positively related to the human resource frame and negatively related to the political and symbolic frames. Although the human resource frame was the most predominant orientation among academic deans; the findings indicate that most deans with a paired frame leadership style were most likely to have a human resource frame and they paired it with the structural frame. Deans with political and symbolic frames were most likely to have a multi-frame leadership style. Comparable to the current study, Russell (2000) found that among community college deans, the preference for structural orientation was negatively correlated with the preference for the political and the symbolic frames.

The current study also showed some significant relationships between leadership frames and styles with conflict management styles. The integrating conflict management style was positively related to all the four leadership frames; opposite to the dominating style which was negatively related to the human resources frame. Donovan (1993) study on academic deans' perceived conflict management styles and their effectiveness found the integrating conflict management style to have a significant positive correlation with effective conflict management. Integrating conflict management style is considered the most effective style because it reflects a high concern for self and others. It aims at reaching an effective solution through the exchange of 
accurate information in order to attain a win-win outcome (Rahim, 1983). Moreover, the study also confirmed the expectation that deans with a human resource frame were least likely to have a dominating conflict management style. This is backed-up by research which indicates that the dominating conflict management style is concerned with addressing the particular concerns of the self at the expense of the needs and expectations of others (Weider-Hatfield, 1988) which contradicts the basic assumptions of the human resources frame that states "organizations exist to serve human needs rather than the reverse" (Bolman \& Deal, 2003, p. 115).

The research also found out that most of the conflict management styles had significant relationships within themselves. The integrating conflict management style was positively related to the obliging and compromising styles and negatively related to the dominating styles. The obliging and compromising styles were also positively related to the avoiding conflict management style. These findings coincide with Donovan (1993) study that found positive correlations between the integrating, compromising, and obliging styles among academic deans. Her study also revealed the integrating style to be negatively correlated to the dominating and avoiding styles which compares with the findings of the current study that shows the integrating style to be negatively related to the dominating style and the compromising style to be positively related to avoiding style. A study by Woodtli (1987) on nursing deans found a negative significant correlation between the compromising conflict management style with avoiding and competing (dominating) conflict management styles. This finding coincides with Donovan's finding that compromising style is negatively related to the dominating style, but it contradicts the current study which found a positive correlation between avoiding and compromising conflict management styles. 


\section{Conclusions}

Although the concepts of leadership and conflict management are age-old, they never cease to fascinate us because of their inherent existence in our organizations. Long before the scientific management era, when the two concepts were scientifically studied, interpersonal conflicts existed and there was need for leaders who could manage them effectively to ensure that goals are met. Nevertheless, the concepts of leadership and conflict are elusive in need of inquiry and understanding (Cantu, 1997; Yulk, 1981). This is because as noted by Cantu (1997) "only when we implement what we know, can we plot courses of improvement" (p. 55). It is the aim of this research that its findings will be used to inform the deanship practice.

The current study was a follow-up of past research that has been done on academic deans' leadership and conflict management styles. Feltner and Goodsell (1972) did a study on academic deans' conflict management styles and acknowledged that academic deans "followed either of the two diametrically opposite theories of conflict" (p.693): Authoritarian or human relations doctrines. Since the early 1970's, when this study was done, so many theories of leadership and conflict management have evolved. As documented in the literature, Feltner and Goodsell's study was done at some point in the behavioral studies era during Blake and Mouton’s managerial grid. In 1964 Robert Blake and Jane Moulton developed the managerial grid with the dimensions of "concern for production" and "concern for people." Years following that, the situational theory emerged to oppose the notion that there is one best style of leadership and advocated that leadership was contingent to the situation.

During the same period of Blake and Mouton's managerial grid, studies on conflict have evolved from viewing disputes from the classical or authoritarian and the human relations perspectives to viewing them from the interactionist view. The interactionist view emerged in 
the early 1970's with an assumption that conflict was not only acceptable but was a legitimate, inevitable, and positive indicator of effective organizational management (Cetin \& Hacifazlioglo, 2004; Rahim, 1983). Hence, the passage of time and the evolution of various studies over time; all support the need to study the concepts of leadership and conflict management styles among academic deans in the $21^{\text {st }}$ century.

In the last few decades various theorists emerged with leadership theories that aim at distinguishing leadership and management: Power and influence theories; cultural and symbolic theories; and the most recent the cognitive theories. Bolman and Deal consolidated major organizational thoughts into four cognitive perspectives that they labeled as frames referring to 'windows, maps, tools, lenses, orientations, and perspectives (Bolman \& Deal, 2003, p.12) that leaders use to understand their organization. The four frames were identified as structural, human resources, political, and symbolic frames. Bolman and Deal asserted that leaders who use the multi-frame or balanced leadership approach could yield effective leadership. They also identified the structural frame with managerial effectiveness and symbolic frame with leadership effectiveness. The human resources and political frames were identified to be the best predictors of managerial and leadership effectiveness (Bolman \& Deal, 1991a).

Similar to Bolman and Deal's framework, higher education institutions are identified to be founded on four conceptual models: Bureaucratic, collegial, political, and anarchical (Baldridge, 1971; McCarty \& Reyes, 1987). Consequently, studies on conflict management in higher education have also been developed from a similar model (Dee, et al., 2004). Although the four models are evident in institutions of higher learning the collegial model is the most prevalent among academic deans (Cantu, 1997; Martin, 1993). The collegial model assumes that the university is a community of scholars with professional lines of authority and adheres to the 
principal that academic deans are "first among equals" in the academic community. This perspective is demonstrated in this study in that the human resources frame and the integrating conflict management styles were the most predominant dispositions among academic deans. Both styles reflect a humane orientation in which the leader is considerate and allows for participative decision making.

The conclusions of the first research question hence, are that all the frames were evident among academic deans in business and education colleges; however, they were employed at different degrees by deans in the two colleges: the human resource frame was the most prevalent among all the deans whereas the political and symbolic frames were the least used frames across the board. This finding is consistent with Bolman and Deal (1991a) observation that skills in political and symbolic frames are more difficult to develop than those in structural and human resources frames. The study also found that deans who headed small faculty sizes scored higher means in all the frames but for the structural frame. Although there were no significant differences with the large faculty sizes; it can be inferred that as group sizes increases leaders become less personal, collegial, and caring toward their employees and tend to be more structured and impersonal (Bass, 1990).

From the findings of the second research question a business dean was least likely to acknowledge the use of the political frames than an education dean. This finding compares to Cantu (1997) study that revealed effective health professional deans to have significantly more political and symbolic leadership orientation than effective science oriented deans. The conclusion of this finding is therefore, as elaborated by situational theorist, leadership is contingent to situation. It could be inferred that there are specific attributes in either business or education colleges that make leaders in each of the colleges more apt to employ some leadership 
frames more than others. As stated by Bolman and Deal (2003) some environments are suited by some frames more than others: for instance the structural frame is more essential for understanding stable organizations with clear lines of authority; the human resources frame is useful in stable organizations in which constituents' preference is developed by consensus through interactions; the political frame prevails in environments that host a complex web of individual and group interests, and finally the symbolic frames are dominant in highly complex environment in which stakeholders are in constant need to find meaning to situations. However, since the political frame is associated with effective leadership (Bolman \& Deal, 1991a; Cantu, 1997); additional experience (Cantu, 1997; Russell, 2000); high levels of scholarship (Russell, 2000); differences in environment and training (Bolman \& Deal, 2003); more research need to be done to identify the specific variables that could result to the differences in orientations among the business and education deans. It could also be important to unveil the dean's attitudes toward the political frame.

Although the political frame is associated with effective leadership, some elements in the frame such as the concepts of power, conflict, competition, and organizational conflict, which are all inherent in the political frame, may have negative connotations within some sectors and hence likely to sway respondents, and in this case the business deans, from indicating the political frame as their preferred or pre-disposed choice of leadership frame.

From the findings of the third research question, although a positive significant relationship existed between the integrating conflict management style with all the four frames; the dominating conflict management style was negatively related to the human resources frame. This finding coincides with studies that show integrating to be the most effective and dominating to be the most ineffective conflict management styles. However, as noted by Munduate et al., 
(1999) the effectiveness of a conflict handling method is as a result of combining different styles of conflict rather than the absence or presence of a particular style. They suggested that the combination of integrating, dominating, and compromising styles to be most effective more than the sole use of any of the styles separately. Hence, a suggestion for future research would be to identify the combination of deans' conflict management styles and their relationship with leadership effectiveness.

This research found some interesting contradictory findings which require additional research to substantiate them or which would suggest a paradigm shift from the perspectives held two decades ago. The first contradictory finding was the prevailing use of the multi-frame leadership style among the deans; this contradicts Bolman and Deal (1991a) observation that revealed that fewer than $25 \%$ of higher education administrators have a multi-frame leadership style and less than $1 \%$ have all the four frames. Even more interesting was that almost half of all the education deans in this study were revealed to have a multi-frame leadership style. Nevertheless, it is important to note that this was a self-report study, and therefore there would be tendency for respondents to bias their self-perceptions. A suggestion for future research would be to replicate the study with the 'other' versions of the leadership orientation questionnaire to find out if the leadership frames and styles revealed in this study hold under different circumstances. Another suggestion would be to replicate Bolman and Deal (1991a) study on all higher education administrators to find out if there is a paradigm change in leaders' orientations.

Similar to the inconsistency with Bolman and Deal's findings, the current study found that deans with fewer than five years of experience in the position of an academic dean were significantly more likely to espouse a human resources frame than deans with more experience. More interesting to note is that the deans with less experience in this study also scored higher 
mean scores on all the frames than deans with more experience. However, as noted earlier, this research was a self-report study and hence, more research need to be done to evaluate the dean's frames from a comprehensive approach involving their superiors, subordinates, and peers to approve these findings. Further suggestion for research would be to study the effect of leadership training and especially training on reframing organization, developed by Bolman and Deal and other theorists of the time, on deans who are new in the position. This study gives consideration that leadership training, offered in the last two decades, and the emphasis on human orientations in higher education institutions may have influenced deans' multiple orientations and choice of leadership frames and conflict management styles. However, more research should be done to delve deeper on this topic.

\section{Recommendations for Practice}

1. Professional development programs should be developed to enlighten the academic deans on the leadership frames and the different conflict management styles and the role of their personal dispositions in choosing the various styles. This is because; leadership is introspective and can only be attained through reflection and self knowledge.

2. Academic deans, and especially business deans, need to be informed on the positive influence of developing the political frame because academic institutions are usually traversed with various political scenarios and situations.

3. Experienced deans should be offered occasional re-treats to energize or inspire their use of the four frames; because the current study showed that dean with less experience scored significantly higher mean scores on the human resources frame among other frames. 
4. Both experienced and inexperienced deans should be equipped with strategies to handle conflicts through the collaboration methods because as noted by Rahim (1983), the over reliance of the compromising conflict management styles could be dysfunctional and could result to a recurrence of the conflict situation because neither of the parties is satisfied with the outcome.

5. Mentorship programs, organized internships, and specialized training can be offered to the new deans to ease their transition process and assist them in accustoming to the new deanship roles.

6. Practical knowledge on academic deans' leadership and conflict management should be incorporated in the higher education text books to offer practical knowledge to prospective academic deans.

\section{Recommendations for Future Research}

1. The results of this study should be further tested using the 'other' version of the leadership orientation instrument (LOI) and the superior or peer version of the Rahim organization conflict inventory (ROCI-II) to enhance knowledge of academic deans leadership and conflict management orientations.

2. A similar study should be done on the other categories of Carnegie classifications such as research institutions and community colleges to find out if there are significant similarities or differences between the leadership orientations and conflict management styles of deans in other institutions. This knowledge will expand the understanding of these two important functions of leaders among academic deans in higher education institutions. 
3. A replica study should also be done on private masters' institutions to find out if there are significant differences associated with type of institution.

4. Further research should be done to investigate the leadership frames of academic deans in business and education colleges and offer suggestions for the differences in the use of the political frames.

5. Replica studies of research done in the past two decades on leadership frames and conflict management styles should be done to identify any significant differences accounted for by the passage of time and training on higher education administrators across the board.

6. Future research should be done to identify the conflict management style, or the combination of conflict management styles, that would yield effective leadership among academic deans. 


\section{References}

Allan, E. J., Gordon, S. P., \& Iverson, S. V. (2006). Re/Thinking practices of power: The discussive framing of leadership in the chronicle of higher education. The Review of Higher Education, 30(1), 41-68. Retrieved from http://muse.jhu.edu/journals/review_of higher_education/v030/30.1allan.pdf

Baldridge, V. J. (1971). Power and conflict in the university: Research in the sociology of complex organizations. Stanford, California: John Willey and Sons Inc.

Baron, R. A. (1989). Personality and organizational conflict: Type A behavior pattern and selfmonitoring. Organizational Behavior and Human Decision Processes, 44, 281-297. doi: $10.1016 / 0749-5978(89) 90028-9$

Bass, B. M. (1990). From transformational to transactional leadership: Learning to share the vision. Organizational Dynamics, 18(3), 19-31.

Bensimon, E. M. (1987). The meaning of "good presidential leadership": A frame analysis. Paper presented at the ASHE annual meeting paper. Retrieved from ERIC database. (ED 292416)

Bensimon, E., Neumann, A., \& Birnbaum, R. L. (2000). Higher education and leadership theory. In C. M. Brown (Ed.), Organization and Governance in Higher Education $\left(^{\text {th }}\right.$ ed., pp. 214-222). Boston, MA: Person Custom publishing.

Ben-Yoav, O., \& Banai, M. (1992). Measuring conflict management styles: A comparison between the MODE and ROCI-II instrument using self and peer ratings. The International Journal of Conflict Management, 3(3), 237-247. doi: 10.1108/eb022714

Blake, R. R., \& Mouton, J. S. (1964). The managerial grid. Houston, Texas: Gulf. 
Blake, R. R., \& Mouton, J. S. (1985). The managerial grid II: A new look at the classic that has boosted productivity and profits for thousands of corporations worldwide. Houston: Gulf Publishing Company

Bolman, L. G., \& Deal, T. E. (1991a). Leadership and management effectiveness: A multi-frame, multi-sector analysis. Human Resource Management, 30, 509-534. doi:10.1002/hrm.3930300406

Bolman, L. G., \& Deal, T. E. (1991b). Images of leadership: Occasional Paper No. 7. Paper presented at the National Center for Educational Leadership. Retrieved from ERIC database. (ED332345)

Bolman, L. G., \& Deal, T. E. (1992). Leading and managing: Effects of context, culture and gender. Educational Administration Quarterly, 28, 314-329. Retrieved from ERIC database. (EJ447155)

Bolman, L. G., \& Deal, T. E. (1997). Reframing organizations. San Francisco: Jossey-Bass.

Bolman, L. G., \& Deal, T. E. (2003). Reframing Organizations: Artistry, choice, and leadership (3rd ed.). San Francisco, CA: Jossey-Bass.

Brown, D. L. (1983). Managing conflict at organizational interfaces. Reading, MA: AddisonWesley.

Burke, R. J. (1970). Methods of resolving superior-subordinate conflict: The constructive use of subordinate differences and disagreement. Organizational Behavior and Human Performance, 5, 393-411. doi: 10.1016/0030-5073(70)90029-2

Burns, J. M. (1978). Leadership. New York: Harper and Row Publishers. 
Cantu, D. A. (1997). The leadership frames of academic deans randomly selected and nominated as exceptionally effective at public colleges and universities (Unpublished doctoral dissertation). Arkansas State University, Arkansas.

Carnegie Classification, F. (2010). The Carnegie foundation for the advancement of teaching. Retrieved 5th January, 2010: http://classifications.carnegiefoundation.org/lookup listings/institution.php

Cetin, M. O., \& Hacifazlioglu, O. (2004). Academics' conflict management styles. Dogus Universitesi Dergisi, 5(2), 155-162. Retrieved from http://journal.dogus.edu.tr/13026739/2004/cilt5/sayi2/M00114.pdf

Chang, T. (2004). Leadership styles of department chairs and faculty utilization of instructional technology (Unpublished doctoral dissertation). West Virginia University, West Virginia.

Chang- Won, L. (2002). Referent roles and styles of handling interpersonal conflicts: Evidence from a national sample of Korean local government employees. The International Journal of Conflict Management, 13(2), 127-141. doi:10.1108/eb022871

Cohen, M. D., \& March, J. G. (1986). Leadership and ambiguity (2nd ed.). Boston MA: Harvard Business School Press.

Cornille, T. A., Pestle, R. E., \& Vanwy, R. W. (1999). Teachers' conflict management style with peers and students' parents. The International Journal of Conflict Management, 10(1), 69-79. doi:10.1108/eb022819

Corson, J. J. (1960). The role of deans. Carbondale and Edwardsville: Southern Illinois University Press. 
Cosier, R. A., \& Dalton, D. R. (1990). Positive effects of conflict: A field assessment. The International Journal of Conflict Management, 1(1), 81-92. Retrieved from http://www.emeraldinsight.com/10.1108/eb022674

Crist, B. E. (1999). A study of the relationship of job satisfaction of chief academic officers of institutions of higher education and the perceived leadership style of the institution's president . Retrieved from Dissertations Abstracts Online (Accession No. AAI9967224)

Dee, R. J., Henkin, A. B., \& Holman, F. B. (2004). Reconciling differences: Conflict management strategies of Catholic college and university presidents. Higher Education 47(2), 177-196. Retrieved from http://www.jstor.org/stable/4151538

Derr, C. B. (1978). Managing organizational conflict: Collaboration, bargaining, power approaches. California Management Review, 21, 76-83. Retrieved from ERIC database. (ED120905)

Deutsch, M. (1949). A theory of cooperation and competition. Human Relations, 2, 129-151. doi: $10.1177 / 001872674900200204$

Dewulf, A., Gray, B., Putnam, L., Lewicki, R., Aarts, N., Bouwen, R., \& Woerkum, C.V. (2009). Disentangling approaches to framing conflict and negotiation research: A metaparadigmatic perspective. Human Relations, 62(2), 155-193. Retrieved from http:/hum.sagepub.com/cgi/content/absract/62/2/155

Dibden, A. J. (Ed.). (1968). The academic deanship in American colleges and universities: Southern Illinois University Press.

Dill, D. D. (1982). The management of academic culture: Notes on the management of meaning and social integration. In C. M. Brown (Ed.), Organization and governance in higher education (5th ed., pp. 261-272). Boston, MA: Pearson Custom Publishing. 
Donovan, M. M. (1993). Academic deans and conflict management: The relationship between perceived styles and effectiveness of managing conflict (Unpublished doctoral dissertation). Marquette University, Wisconsin.

Dupont, G. E. (Ed.). (1956). The dean and his office. Washington DC: The Catholic University of America Press.

Drucker, P. F. (1999). Management challenge for the 21st century. New York, NY: Harper Business Book.

Englett, M. G. (2008). Leadership orientations of rural community college presidents serving appointed or elected independent governing boards: A four-frame analysis (Doctoral dissertation). Retrieved from http://proquest.umi.com/pqdlink?Ver=1\&Exp=01-29$\underline{2015 \& \mathrm{FMT}=7 \& \mathrm{DID}=1579168331 \& \mathrm{RQT}=309 \& \mathrm{attempt}=1 \& \mathrm{cfc}=1}$

Fagin, M. C. (1997). The leadership role of a dean. New Directions for Higher Education, 98, 95-99. doi: 10.1002/he.9809

Fairhurst, G. T. (2005). Reframing the art of framing: Problems and prospects for leadership. Leadership, 1(2), 165-185. doi: 10.1177/1742715005051857

Feltner, B. D., \& Goodsell, D. R. (1972). The academic dean and conflict management. Journal of Higher education, 43(9), 692-701. Retrieved from http://www.jstor.org/stable/1979000

Field, A. (2005). Discovering statistics using SPSS (2nd ed.). New Delhi, London: Sage Publications.

Fink, C. F. (1968). Some conceptual difficulties in the theory of social conflict. Journal of conflict resolution, 12, 412-460. Retrieved from http://www.jstor.org/stable/pdfplus/173460.pdf 
Fisher, R., Ury, W., \& Patton, B. (1991). Getting to Yes: Negotiating agreement without giving in. New Zealand: Penguin Books.

Garnier, B. (1981). The impact of conflict-handling modes of academic deans on their perceived managerial effectiveness: An empirical study in selected Canadian universities (Unpublished doctoral dissertation). University of Western Ontario, Canada.

Geiger, J. (1989). Education deans as collaborative leaders. Journal of Teacher education, 40(6). doi: $10.1177 / 002248718904000601$

Gmelch, W. H., Wolverton, M., Wolverton, M. L., \& Sarros, J. C. (1999). The academic dean: An imperiled species searching for balance. Research in higher education 40(6), 24. doi: 10.1023/A:1018717015528

Gould, J. W. (1964). The academic deanship. In A. J. Dibden (Ed.), Academic deanship in American colleges and universities. Carbondale: Southern Illinois University Press

Griffin, M. S. (2005). A comparison of the leadership orientations of chairpersons of biology and English departments at baccalaureate and master's institutions in the southern region (Doctoral dissertation). Retrieved from Dissertation Abstracts Online. (Accession No.AAI3170917)

Guidry, T. C. (2007). Women dean's perception of their leadership styles: A study based on Bolman and Deal's four frame theory (Unpublished doctoral dissertation). East Carolina University, North Carolina.

Halpin, A. W., \& Winer, B. J. (1957). A factorial study of the Leader Behavior Descriptions. In R. M. Stogdill \& A. E. Coons (Eds.), Leader Behavior: Its descriptions and measurement. Columbus: The Ohio State University, Bureau of Business Research 
Heck, R. H., Johnsrud, L. K., \& Rosser, V. J. (2000). Administrative Effectiveness in higher education. Research in higher education, 41(6), 663-684. doi:

10.1023/A:1007096803784

Hendel, T., Fish, M., \& Galon, V. (2005). Leadership style and choice of strategy in conflict management among Israel nurse managers in general hospitals. Journal of Nursing Management, 13, 137-147. Retrieved from http://www.hadassahmed.com/NR/rdonlyres/ED5DF973-5859-4C52-AABD0A84D049CCA8/16622/Leadership20style20and20choice20of20strategy20in20.pdf

Hersey, P., Blanchard, K. H., \& Johnson, D. E. (1996). Management of organization behavior: Utilizing human resources (7th ed.). Upper Saddle River, NJ: Prentice Hall.

Higher Education Publications, I. (2010). The Higher Education directory. Retrieved 5th January, 2010: http://www.hepinc.com/index.php

Hoffman, M. (2007). Does sense of humor moderate the relationship between leadership style and conflict management style (Doctoral dissertation). Available through Dissertation Abstracts Online. (AAI3284029)

Hofstede, G. (1984). Culture's consequences: International differences in work-related values. Newbury Park, California: Sage Publications.

Jones, R. E., \& White, C. S. (1985). Relationships among personality, conflict resolutions styles, and task effectiveness. Group and organization studies, 10(2), 152-167. doi: $10.1177 / 105960118501000204$

Jordan, P. J., \& Troth, A. C. (2002). Emotional intelligence and conflict resolution: Implications for human resource development. Advances in developing human resources, 4(62). doi: $10.1177 / 1523422302004001005$ 
Kaplowitz, N. (1984). Psychopolitical dimension of international relations. International Studies Quarterly, 28, 373-409. Retrieved from http://www.jstor.org/stable/pdfplus/2600562.pdf

Kaufman, S., Elliot, M., \& Shmueli, D. (2003). Frames, framing and reframing: The beyond intractability project. Retrieved from http://crinfo.beyondintractability.org/essay/framing

Keeter, S., Kennedy, C., Dimock, M., Best, J., \& Craighill, P. (2006). Gauging the impact of growing non-response on estimates from a national RDD telephone survey. Public Opinion Quarterly, 70(5), 759-779. doi: 10.1093/poq/nf1035

Kreitner, R. (1980). Management: A problem solving process. Boston: Houghton Mifflin.

Kreitner, R., \& Kinicki, A. (1989). Organizational behavior. Boston, MA: Richard D. Irwin Inc.

Kuh, G. D., \& Whitt, E. J. (1988). Culture in American colleges and universities. In C. M. Brown (Ed.), Organization and governance in higher education (5th ed., pp.160-169). Boston, MA: Pearson Custom Publishing.

Landa-Gonzales, B. (2008). To assert or not to assert: Conflict management and occupational therapy students'. Occupational Therapy in Health Care, 22(4), 54-70. doi: $10.1080 / 07380570802244464$

Lawrence, P. R., \& Lorsch, J. W. (1967). Organization and environment: Managing differentiation and integration (Doctoral dissertation). Retrieved from http://glennschool.osu.edu/faculty/brown/home/Org\%20Theory/Readings/Organization\% 20and\%20Environment.pdf

Leslie, D. W. (1972). Conflict management in the academy: An exploration of the issues. Journal of Higher education, 43(9), 702-719. Retrieved from http://www.jstor.org/stable/pdfplus/1979001.pdf

Likert, R. (1961). New patterns of management. New York: McGraw-Hill. 
Lovelace, K., Shapiro, D., \& Weingart, L. R. (2001). Maximizing cross-functional new products teams' innovativeness and constant adherence: A conflict communications perspective. Academy of Management Journal, 44(4), 479-493. Retrieved from http://www.jstor.org/stable/pdfplus/3069415.pdf

Lucas, C. J. (1996). American higher education: A history. New York, NY: St. Martins Press.

Masland, T. A. (1985). Organizational culture in the study of higher education. In C. M. Brown (Ed.), Organization and governance in higher education (5th ed., pp.145-152). Boston, MA: Person Custom Publishing.

Martin, J.L (1993, April). Academic deans: An analysis of effective academic leadership at research universities. Paper session presented at the Annual Meeting of American Educational Research Association, Atlanta, GA.

McArdle, M. K. (2008). Leadership orientations of community college presidents and the administrators who report to them: A frame analysis (Doctoral dissertation). Available from Dissertation Abstract online (AAI3335355)

McCarty, D. J., \& Reyes, P. (1987). Organizational models of governance: Academic deans' decision making styles. Journal of Teacher education, 38, 2-8. doi: $10.1177 / 002248718703800502$

McGinnis, F. A. (1933). The dean and his duties. The journal of Higher Education, 4(4), 191196. Retrieved from http://www.jstor.org/stable/pdfplus/1975720.pdf

McGrath, E. A. (1938). The evolution of administrative offices in institutions of higher education in the United States from 1860 to 1933 . Chicago. 
Mintzberg, H. (1975). The manager's job: Fact and folklore. Harvard Business Review, 53, 49-

61. Retrieved from http://courseweb.glendale.edu/ppal/Busad\%20101/mintzbergmar1990.pdf

Monahan, M. L. (2004). Leadership frames of presidents of Master I Higher education (Doctoral dissertation). Retrieved from Dissertations Abstracts Online (Accession No. AAI3152275)

Montez, J. M., Wolverton, M., \& Gmelch, W. H. (2002). The roles and challenges of deans. The Review of Higher Education, 26(2), 241-266. Retrieved from http://muse.jhu.edu/journals/review_of higher_education/v026/26.2montez.pdf

Morrill, C. (1991). The customs of conflict management among corporate executives. American Anthropologist, 93, 871-893. Retrieved from http://www.jstor.org/stable/pdfplus/680968.pdf

Mosser, N. R., \& Walls, R. T. (2002). Leadership frames of nursing chairpersons and the organization climate in Baccalaureate nursing programs. Southern online journal of nursing research, 3(2), 1-11. Retrieved from http://www.snrs.org/publications/SOJNR_articles/iss02vol03.pdf

Munduate, L., Ganaza, J., Peiro, J. M., \& Euwema, M. (1999). Patterns of styles in conflict management and effectiveness. The International Journal of Conflict Management, 10(1), 5-24. doi: 10.1108/eb022816

Olsen, G. L. (1986). The relationship of organizational institutional differentiation and the academic dean in an institution of higher education as defined by conflict, power, and leadership style (Unpublished doctoral dissertation). Wisconsin University, Milwaukee. 
Olson, G. A. (2007, September 20). The delicate art of rejection. The Chronicles of Higher Education: Academe Today. Retrieved from http://chronicle.com/article/The-Delicate$\underline{\text { Art-of-Rejection/46640/ }}$

Ouchi, W. G. (1981). Theory Z: How American business can meet the Japanese challenge. MA: Addison-Wesley

Pascale, R. T., \& Athos, A. J. (1981). The art of Japanese management. New York: Simon and Schuster.

Peterson, M. W., \& Spencer, M. G. (1990). Understanding academic culture and climate. In C. M. Brown (Ed.), Organization and governance in higher education (5th ed., pp.170-181). Boston, MA: Pearson Custom Publishing.

Pinkley, R. L., \& Northcraft, G. B. (1994). Conflict frames of reference: implications for dispute processes and outcomes. Academy of Management Journal, 37(1), 193-205. Retrieved from http://www.jstor.org/stable/pdfplus/256777.pdf

Pondy, L. R. (1967). Organizational Conflict: Concepts and Models. Administrative Science Quarterly, 12(2), 296-320. Retrieved from http://www.jstor.org/stable/pdfplus/2391553.pdf

Rahim, M. A. (1983). A measure of styles of handling interpersonal conflict. Journal of Social Psychology, 126, 79-86. Retrieved from http://www.jstor.org/stable/pdfplus/255985.pdf Rahim, M. A. (1985). A strategy for managing conflict in complex organizations. Human Relations, 38(1), 81-89. doi: 10.1177/001872678503800105

Rapport, A. (1966). Experiments in dyadic conflict \& cooperation. Bulletin of Menninger Clinic, 30(5), 284-291. Retrieved from http://www.ncbi.nlm.nih.gov/pubmed/5915784 
Robbins, S. P. (1996). Organizational behavior: Concepts, controversies, application (7th ed.). Englewood Cliffs, NJ: Prentice Hall.

Rosser, V. J., Johnsrud, L. K., \& Heck, R. H. (2003). Academic deans and directors: Assessing their effectiveness from individual and institutional perspectives. The Journal of Higher Education, 74(1), 1-25. Retrieved from http://www.questia.com/googleScholar.qst;jsessionid=LkxcfLr2FHmQ14cWDgjrlypsnsT $\underline{\text { RqRvJpDLxVL1YLwljvGpkfj0n!1680139891!2038965103?docId=5000603122 }}$

Rudolph, F. (1962). The American college and university: A history. New York.

Russell, C. A. (2000). College academic deans: Leadership frames and stress (unpublished doctoral dissertation). Iowa State University, Iowa.

Sasnett, B., \& Ross, T. (2007). Leadership frames and perceptions of effectiveness among health information management program directors. Perspectives in Health Information Management, 4(8). Retrieved from http://www.ncbi.nlm.nih.gov:80/pmc/articles/PMC2047298/pdf/phim0004-0008.pdf

Satterlee, A. G. (2002). Conflict resolution strategies for the adult higher education student. Retrieved from ERIC database. (462055)

Schein, E. (1992). Three levels of culture. Retrieved from http://www.valuebasedmanagement.net/methods_schein three levels culture.html

Stanley, C. A., \& Algert, N. E. (2007). An exploratory study of the conflict management styles of department heads in a research university setting. Innovative Higher Education, 32, 49-65. doi: 10.1007/s10755-007-9035-y

Suskie, L. A. (1996). Questionnaire survey research: What works (2nd ed.). Tallahassee, Florida: Association for Institutional Research. 
Sypawka, W. (2008). A study of division deans in the North Carolina community college system: Self-perceived leadership style based on Bolman and Deal's four frame theory (Doctoral dissertation). Retrieved from Dissertation Abstracts Online (Accession No. AAI3303589)

Thomas, K. W. (1976). Conflict and conflict management. In M. D. Dunnette (Ed.), Handbook of Industrial and Organizational Psychology. Palo Alto CA: Consulting Psychologist Press.

Thomas, K. W. (1988). The conflict-handling modes: Toward more precise theory. Management Communication Quarterly, 1, 430-436. doi:_10.1177/0893318988001003009

Thomas, K. W. (1992). Conflict and negotiation process in organizations. In M. D. Dunnette \& L. M. Hough (Eds.), Handbook of Industrial and Organizational Psychology (pp. 651717). Palo Alto CA: Consulting Psychologist Press.

Thompson, M. D. (2000). Gender, leadership orientation and effectiveness: Testing the theoretical models of Bolman and Deal and Quinn. Sex roles, 42(11/12), 24. doi: 10.1023/A:1007032500072

Tierney, W. (1989). Symbolism and presidential perceptions of leadership. In C. M. Brown (Ed.), Organization and Governance in Higher Education (5 ${ }^{\text {th }}$ ed., pp. 223-231). Boston, MA: Person Custom Publishing.

Turker, A., \& Bryan, R. A. (1991). The academic dean: Dove, dragon and diplomat (2nd ed.). New York: McMillan Publishing Company.

Visser, P. S., Krosnick, J. A., Marquette, J., \& Curtin, M. (1996). Mail surveys for election forecasting: An evaluation of the Columbus dispatch poll. The American Association for Public Opinion Research, 60, 181-227. Retrieved from: http://poq.oxfordjournals.org/ 
Volpe, M. R., \& Chandler, D. (1998). Resolving conflict in institutions of higher education: Challenges for pracademics. Retrieved from http://law.gsu.edu/cncr/pdf/papers/992Volpepap.pdf

Wall., J. A., \& Callister, R. R. (1995). Conflict and its management. Journal of Management, 21(3), 515-558. doi: 10.1177/014920639502100306

Ward, M. S. (1934). The philosophies of administration current in the deanship of the liberal arts college. New York: Bureau of publications, Teachers College Columbia University.

Way, L. J. (2010). The impact of disciplinary on the organizational leadership styles of academic dean (Doctoral dissertation, University of Massachusetts). Retrieved from $\underline{\text { http://scholarworks.umass.edu/cgi/viewcontent.cgi? article }=1192 \& \text { context }=\text { open access }}$ $\underline{\text { dissertations }}$

Weider-Hatfield, D. (1988). Assessing the RAHIM organizational conflict inventory -II (ROCI-II). Management Communication Quarterly, 1(3), 350-366.

Wolverton, M., \& Gmelch, W. H. (2002). College deans: Leading from within. Westport, CT: American Council on Education Oryx Press.

Wolverton, M., Wolverton, L. M., \& Gmelch, W. H. (1999). The impact of role conflict and ambiguity on academic deans. The Journal of Higher Education, 70(1), 80-106. Retrieved from http://www.questia.com/googleScholar.qst?docId=5001235708

Womack, D. F. (1988). Assessing the Thomas-Kilmann Conflict Mode Survey. Management Communication Quarterly 1(3), 321-349. doi: $10.1177 / 0893318988001003004$

Woodtli, A. O. (1987). Deans of nursing: Perceived sources of conflict and conflict-handling modes. Journal of Nursing Education, 26(7), 272-277. 
Yerkes, D., Cuellar, M.-F., \& Cuellar, A. (1992, April). Towards an understanding of organizational culture in schools of education: Implications for leadership development. Paper presented at the American Educational Research Association, San Francisco, California.

Yulk, G. A. (1981). Leadership in organizations. Englewood Cliffs, NJ: Prentice-Hall Inc. 
Appendices A, B, C, D, E,F 
Appendix A: IRB Review 


\section{Appendix A: IRB Review}

Subject: BRAAN2: IRB Protocol Marked as Exempt

To: paul chapman, Linda Nkirote Kimencu , pchapman@mail.wvu.edu

Cc:

Date: 05/14/10 03:03 PM

From:wvuecomp@wvu.edu

Reply-To:

Bcc:

The following IRB Protocol has been marked as Exempt.

Tracking \#: H-22469

PI: Chapman, Paul

Title: Leadership Orientations and Conflict Management Styles of Academic Deans in Masters Degree Institutions

The BRAAN2 website can be accessed by clicking the following link: BRAAN2 Login 
Appendix B: Dean's Cover Letter 


\section{Appendix B: Dean's Cover Letter}

To: [Email]

From: 1kimencu@gmail.com

Date: June $10^{\text {th }}, 2010$

Subject: Leadership and Conflict management survey instrument

Body: Dear Dean [LastName],

Leadership and conflict management are integral functions of academic leaders. However, limited research has been done to evaluate deans' leadership and conflict management styles in Higher education administration. Therefore, I am requesting your participation in an investigation of these two essential roles of leadership. This study constitutes one of the requirements to complete my doctorate in the department of Educational Leadership Studies at West Virginia University.

The study aims to identify the leadership frames (cognitive perspectives) and conflict management styles of academic deans in Public Masters Colleges and Universities across the United States. The findings of this research will be essential in understanding the role of academic deans in Higher education and offer recommendations on these two leadership functions. The Leadership and Conflict management questionnaires will take approximately 10-15 minutes of your time to complete. This research has been approved by the West Virginia University Institution Review Board (IRB). Hence, all names of participants and institutions will remain anonymous in the final research report. Your questionnaires will be identified by a code for follow-up purposes only. Your participation in this research is entirely voluntary.

Here is a link to the survey:

http://www.surveymonkey.com/s.aspx

For questions regarding this study, please contact me by Email at 1kimencu@gmail.com or you can contact my dissertation advisor; Dr. Paul Chapman atPaul.Chapman@mail.wvu.edu

A summary of the findings will be sent to you upon request.

Thank you very much for your time and cooperation.

Sincerely, Linda Kimencu

Doctoral Candidate

Educational Leadership

Please note: If you do not wish to receive further emails from us, please click the link below, and you will be automatically removed from our mailing list.

http://www.surveymonkey.com/optout.aspx 
Appendix C: Dean's Reminder 


\section{Appendix C: Dean's Reminder}

\section{Dean's first reminder}

To: [Email]

From: $\underline{\text { lkimencu@mix.wvu.edu }}$

Date: July $6^{\text {th }}, 2010$

\section{Subject: Leadership and Conflict Management Survey}

Body: Dear Dean [LastName], This is a courtesy reminder of the leadership and conflict management survey that was sent to you approximately three weeks ago. If you have already responded to the electronic survey, thank you very much. If not, I will appreciate your feedback which is very important to the completion of my study.

Here is a link to the survey:

http://www.surveymonkey.com/s.aspx

For any questions regarding the study please Email me at lkimencu@gmail.com or you can contact my dissertation advisor Dr. Paul Chapman at PEChapman@mail.wvu.edu

Thank you very much for your assistance.

Linda Kimencu

Doctoral Candidate

Educational Leadership

West Virginia University

Dr. Paul Chapman, Ph.D

304-293-2174

PEChapman@mail.wvu.edu

Please note: If you do not wish to receive further emails from us, please click the link below, and you will be automatically removed from our mailing list. http://www.surveymonkey.com/optout.aspx 


\section{Dean's second reminder}

To: [Email]

From: 1kimencu@gmail.com

Date: September $7^{\text {th }}, 2010$

Subject: Courtesy Reminder

Body: Dear Dean [LastName],

Thank you so much for taking your time to read my email. One month ago, I sent you a leadership and conflict management survey. I understand that this is the beginning of the semester and you must be very busy. However, I would really appreciate if you could spare at least 10-15 minutes of your time to respond to this survey which is very important to the completion of my study. The study will inform me, educational administrators, and other scholars in general on the relationship between leadership styles and conflict management.

Your response to this survey is truly appreciated.

Here is a link to the survey:

http://www.surveymonkey.com/s.aspx

For any questions regarding the study please Email me at 1kimencu@gmail.com or you can contact my dissertation advisor Dr. Paul Chapman at

PEChapman@mail.wvu.edu

Thank you very much for your assistance.

Linda Kimencu

Doctoral Candidate

Educational Leadership

West Virginia University

Dr. Paul Chapman, Ph.D

304-293-2174

PEChapman@mail.wvu.edu

Please note: If you do not wish to receive further emails from us, please click the link below, and you will be automatically removed from our mailing list.

http://www.surveymonkey.com/optout.aspx 
Appendix D: Permission to use Leadership Orientation Instrument (LOI-Self) 


\section{Appendix D: Leadership Orientation Instrument (LOI-Self)}

From: Linda

Monday - March 8, 2010 10:51 AM

Kimencu

To: bolmanl@umkc.edu

BC: Sucha@slocoast.net

Subject: Permission to use LOI (self version)

Hello Dr.Bolman,

I am a doctoral student in Educational Leadership Studies at West Virginia University. I would like to request for permission to use the Leadership Orientation Inventory (self version) as a tool to evaluate academic dean's leadership frames and styles.

A copy of the research findings will be sent to you upon completion of the dissertation.

Please advise me on the costs and conditions involved in accessing and distribution of the document

Thanks,

Linda Kimencu

Ed.D Leadership Studies

West Virginia University 
Permission to use Leadership Orientation Instrument (Self)

From: "Bolman, Lee G."

$<$ BolmanL@umkc.edu $>$

To: Linda Kimencu <Linda.Kimencu@mail.wvu.edu $>$

Subject: RE: Permission to use LOI (Self version)

Attachments: Mime.822 (4 KB) [View] [Save As]

Dear Ms. Kimencu:

I'm happy to give you permission to use the Leadership Orientations Instrument, on condition of your agreement to provide us with the results of your research.

Best wishes on your dissertation.

Lee G. Bolman, Ph.D.

Professor and Marion Bloch/Missouri Chair in Leadership

Bloch School of Management

University of Missouri-Kansas City

5100 Rockhill Road

Kansas City, MO 64110

Tel: (816) 235-5407

Web: lee@bolman.com 
Copyright Notice for the Leadership Orientation Instrument retrieved from Lee Bolman's webpage: http://leebolman.com/frames_selfrating_scale.htm

\section{Copyright Notice}

The survey and the scoring handout are both copyrighted. We grant instructors in college and university courses automatic permission to make copies for their students, on condition that the copies carry the copyright notice and author credits. We extend the same permission to students in college and university courses. For questions about permission for other uses, write Lee Bolman at bolmanl@umkc.edu. 


\section{Appendix E: Permission to use Rahim Organizational Conflict Inventory- II}

From: Linda

Kimencu

To:mgt2000@aol.com

Subject: Permission to use ROCI-II instrument

To Whom It May Concern:

Dear Sir/Madam,
Monday - October 19, 2009 3:58 PM

My name is Linda Kimencu, am currently pursuing a doctorate in Educational Leadership Studies at West Virginia University. I am currently writing the proposal phase of my dissertation. My dissertation topic is on the relationship between leadership orientations and conflict management style among academic deans. Am intending to use the ROCI-II instrument because of its practicability in measuring superior, subordinate and peer conflicts which are inherent in the dean's position.

I will appreciate any help given regarding the cost of the questionnaire, its accessibility and all conditions regarding its use.

Any help given will be highly appreciated.

Thanks.

Linda Kimencu

Ed.D Leadership Studies

West Virginia University. 
From: Afzal Rahim <mgt2000@aol.com>

To: <Linda.Kimencu@mail.wvu.edu $>$

Subject: Re: Permission to use ROCI-II instrument

Attachments: Order Form for Questionnaires.doc (103 KB)

Mime.822 (150 KB)

[View] [Open] [Save As]

[View] [Save As]

Dear Ms. Kimencu:

We are glad to know that you are planning to use our conflict instruments (ROCI-II) in your research. We would like to receive a copy of the report when it is completed.

The ROCIs are now published by the Center for Advanced Studies in Management. Please fill out and return the attached Order Form so that we can send you our camera-ready instruments and a complimentary comprehensive Bibliography.

Let us know if you have any other questions.

Thanks.

Mir S. Haque, Manager

Center for Advanced Studies in Management

1574 Mallory Court

Bowling Green, KY 42103, USA

Phone/Fax: 270-782-2601 
From: Afzal Rahim <mgt2000@aol.com>

Tuesday - February 9, 2010 1:30 PM

To: <Linda.Kimencu@mail.wvu.edu $>$

Subject: ROCI-II

Attachments: ROCI-II \& Key (5 point scale).doc (73 KB) [View] [Open] [Save As]

ROCI-Bibl-Revised.doc (131 KB)

Mime.822 (285 KB)

[View] [Open] [Save As]

[View] [Save As]

Dear Ms. Kimencu,

Thank you very much for your order. Attached please find our camera-ready ROCI- II. You are authorized to make upto 300 copies of the instrument.

We would like to receive a copy of your report when it is ready. Attached please find our complimentary ROCI Bibliography which should help in your research.

Good luck with your research.

Thanks.

Mir S. Haque for Dr. Rahim

Manager

Center for Advanced Studies in Management

1574 Mallory Court

Bowling Green, KY 42103, USA

Phone/Fax: 270-782-2601 
Appendix F: Survey Instruments 


\section{Appendix F: Survey instrument}

\section{Section A: Demographic Section}

1. Which of these terms closely define the name of your college (Check one)? College of Education

College of Business

2. What is the name of your terminal degree?

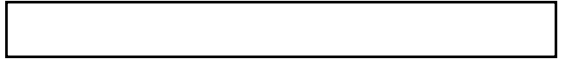

3. Please indicate your gender

Male

Female

4. Please indicate your age group

$30-40$ years

$41-50$ years

51-60 years

Over 60 years

5. How many years have you worked in the current position

Less than three years (Short term)

Three to five years (Medium term)

More than five years (Long term)

6. How many total years have you worked in academia?

Less than Five years

Between Five and Ten years

More than Ten years

7. What is the size of your faculty

Small (10-20 members of faculty)

Medium (21-40 members of faculty)

Large (over 41 members of faculty) 


\section{Section B: LOI- Self version}

Leadership Orientations Inventory (LOI) (self Version)

On a scale of one to five; one referring to 'never' and 5 referring to 'always', Please indicate how often each of the items below is true of you.

\section{Items}

1. I think very clearly and logically

2. I show high levels of support and concern for others

3. I have exceptional ability to mobilize people and resources to get things done

4. I inspire others to do their best

5. I strongly emphasize careful planning and clear time lines

6. I build trust through open and collaborative relationships

7. I am a very skillful and shrewd negotiator

8. I am highly charismatic

9. I approach problems through logical analysis and careful thinking

10. I show high sensitivity and concern for others' needs and feelings

11. I am unusually persuasive and influential

12. I am able to be an inspiration to others

13. I develop and implement clear, logical policies and procedures

14. I foster high levels of participation and involvement in decisions

15. I anticipate and deal adroitly with organizational conflicts

16. I am highly imaginative and creative

17. I approach problems with facts and logic

\section{Never}

(1)

(2)

(3)
Always
(3) (5) 
18. I am consistently helpful and responsive to others

19. I am very effective in getting support from people with influence and power

20. I communicate a strong and challenging sense of vision and mission

21. I set specific, measurable goals and hold people accountable for results

22. I listen well and I am unusually receptive to other people's idea's and inputs

23. I am politically very sensitive and skillful

24. I see beyond current realities to generate exciting new opportunities

25. I have extraordinary attention to detail

26. I give personal recognition for work well done.

27. I develop alliances to build strong base of support.

28. I generate loyalty and enthusiasm

29. I strongly believe in clear structure and a chain of command

30. I am a highly participative manager

31. I succeed in the face of conflict and opposition

32. I serve as influential model of organizational aspirations and values

(C) 1988, Lee G. Bolman and Terrence E. Deal. All rights reserved. This survey is based on ideas in Bolman and Deal's Reframing Organizations: Artistry, Choice and Leadership (San Francisco: Jossey-Bass, 1991, 1997, 2003) (see footnote 3). 


\section{Scoring Key \\ LOI (Self-version)}

Rating scale- Never- 1

Always- 5

1. Structural frame

(Average of 4.0 in each item) $\quad 1,5,9,13,17,21,25,29$

2. Human Resource Frame

(Average of 4.0 in each item) 2,6,10,14,18,22,26,30

3. Political Frame

(Average of 4.0 in each item) $\quad 3,7,11,15,19,23,27,31$

4. Symbolic Frame

(Average of 4.0 in each item) $\quad 4,8,12,16,20,24,28,32$ 


\section{Section C: Rahim Organizational Conflict Inventory-II, Form B}

\section{Strictly Confidential}

Please check the appropriate box after each statement, to indicate how you handle your disagreement or conflict with your subordinates. Try to recall as many recent conflict situations as possible in ranking these statements. Please indicate on a scale of 1-5 with 1 (strongly disagree) and 5 (strongly agree) the extent to which the following statement represents your actions during a conflict situation.

The center for advanced studies in management prohibits researchers from reproducing all the items in the questionnaire in the research report and recommends that researchers provide only one item for each subscale in the instrument.

Integrating conflict management style: I try to investigate an issue with my subordinates to find a solution acceptable to us.

Obliging conflict management style: I generally try to satisfy the needs of my subordinates.

Dominating conflict management style: I use my authority to make a decision in my favor Avoiding conflict management style: I attempt to avoid being "put on the spot" and try to keep my conflict with my subordinates to myself.

Compromising conflict management style: I usually accommodate the wishes of my subordinates

ROCI-II instrument used with permission from the (C) Center for Advanced Studies in Management. Further use or reproduction of the instrument without written permission is prohibited (see footnote 4). 
Scoring Key

ROCI-II Form B

Rating scale: Strongly Agree $=5$

Strongly Disagree $=1$

\section{Integrating Style}

(Average responses to Items $1,4,5,12,22,23,28$ )

2. Obliging style

(Average responses to Items $\quad 2,10,11,13,19,24)$

3. Dominating style

(Average your responses to Items $\quad 8,9,18,21,25$ )

4. Avoiding style

(Average your responses to Items $3,6,16,17,26,27$ )

5. Compromising style

(Average your responses to Items $\quad 7,14,15,20$ ) 


\section{Footnotes}

${ }^{1}$ Figure 1. Represents the five management styles developed on a scale of one to nine indicating the extent to which a manager has concern for people or production. Adapted from "The Managerial Grid III: A new look at the classic that has boosted productivity and profits for thousands of corporations worldwide" by R. R. Blake and J.S Mouton, 1985, p.12. Houston, Copyright 1985 by Gulf Publishing Company. Adapted with permission.

${ }^{2}$ Figure 2. Situational leadership model illustrating a leader behavior in the context of follower readiness and maturity. Adapted from "Management of Organizatonal Behavior: Utilizing Human Resources," by P. Hersey, K.H. Blanchard, and D. E. Johnson, 1996, p. 208. Copyright 1996 by Prentice Hall Inc. Adapted with permission.

${ }^{3}$ C 1988 , Lee G. Bolman and Terrence E. Deal. All rights reserved. This survey is based on ideas in Bolman and Deal's Reframing Organizations: Artistry, Choice and Leadership (San Francisco: Jossey-Bass, 1991, 1997, 2003)

${ }^{4}$ ROCI-II instrument used with permission from the C Center for Advanced Studies in Management. Further use or reproduction of the instrument without written permission is prohibited. 
Personal Bio:

Linda Kimencu is originally from Kenya. She has a bachelors and a master's degree in Business Administration. Her interests are in leadership studies and assessment methodology in higher education institutions. For future correspondence please contact her by Email at $\underline{\text { lkimencu@gmail.com }}$ 